Szegedi Tudományegyetem

Bölcsészettudományi Kar

Irodalomtudományi Doktori Iskola

PhD Értekezés

Maczelka Csaba

\title{
The Uses of Paratextuality and Dialogicity in Early Modern English Utopias
}


Szegedi Tudományegyetem

Bölcsészettudományi Kar

Irodalomtudományi Doktori Iskola

PhD Értekezés

Maczelka Csaba

\section{The Uses of Paratextuality and Dialogicity in Early Modern English Utopias}

Témavezető: Dr. Szőnyi György Endre 


\section{Table of Contents}

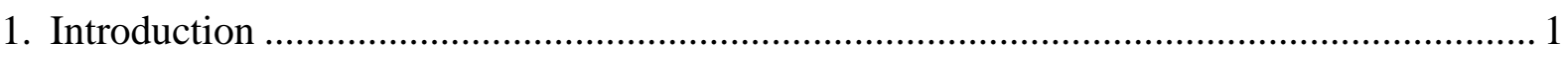

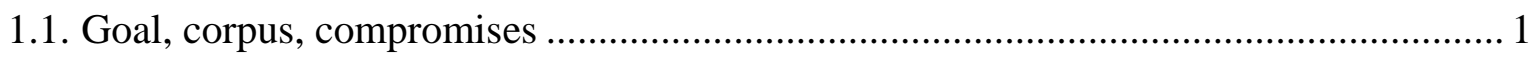

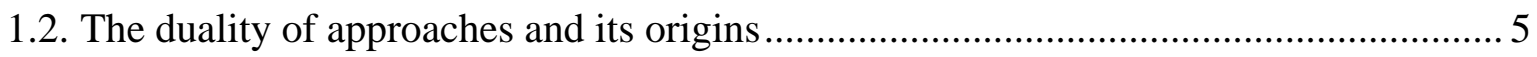

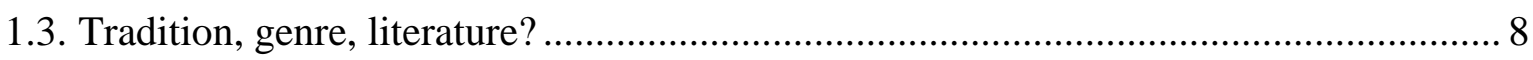

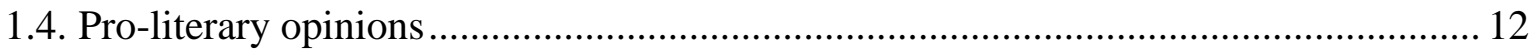

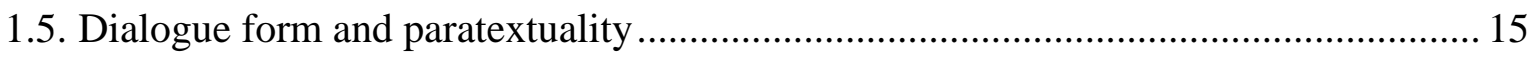

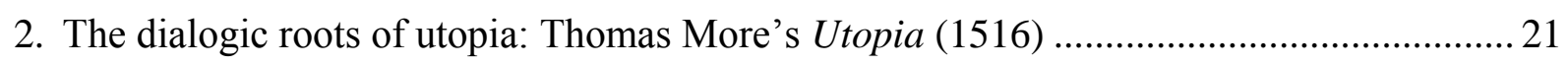

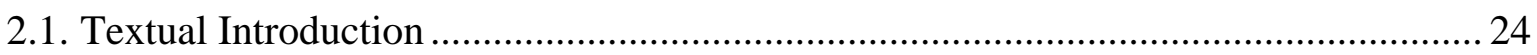

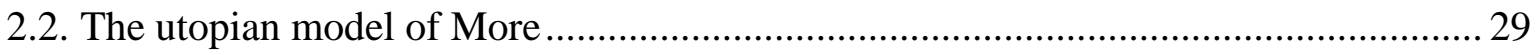

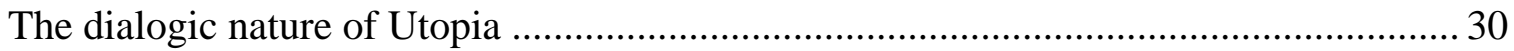

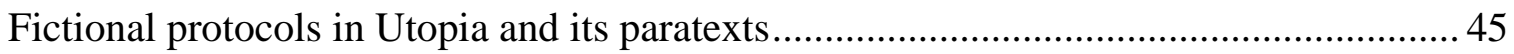

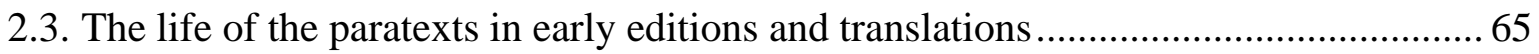

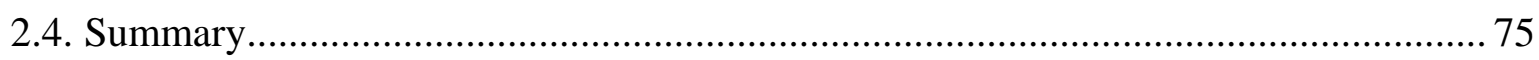

3. Dialogue and utopia in the 1570s-1580s: A Pleasant Dialogue Between a Lady Called

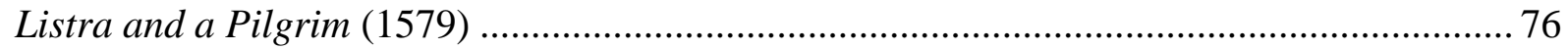

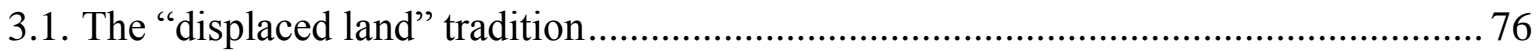

3.2. Tudor dialogues: a problem in literary history …................................................ 81

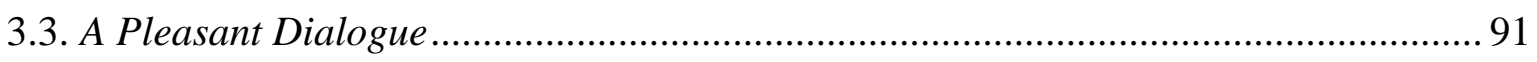

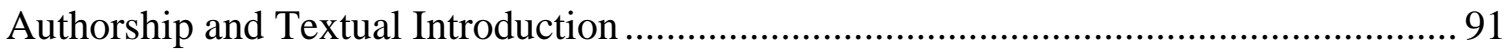

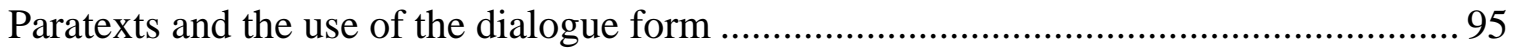

3.4. Summary: a possible approach to A Pleasant Dialogue ............................................. 104

4. Converging traditions. J. Hall's Mundus alter et idem (1605) and J. Haley's Discovery of a

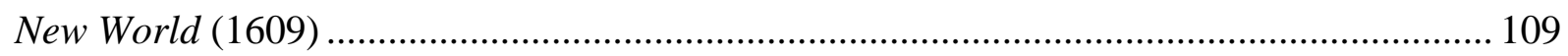

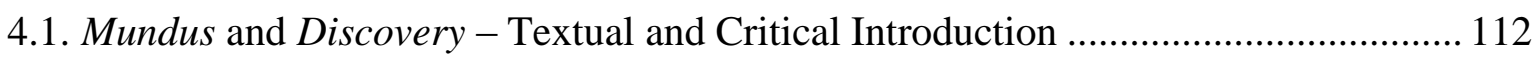

4.2. Dialogicity and Paratextuality in Mundus .............................................................. 117

4.3. Moral issues in Mundus and the Elizabethan dialogues .......................................... 129

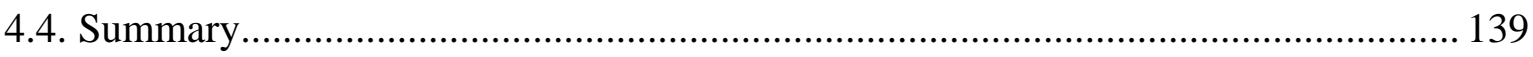

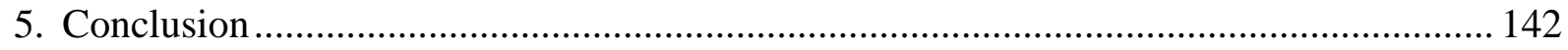

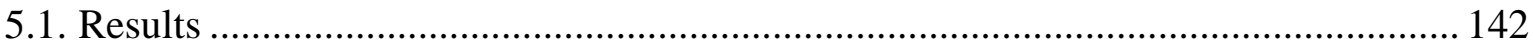

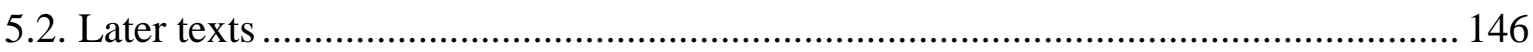




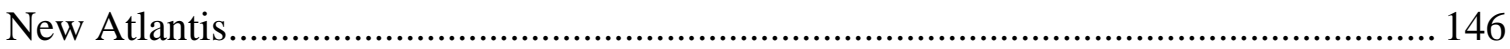

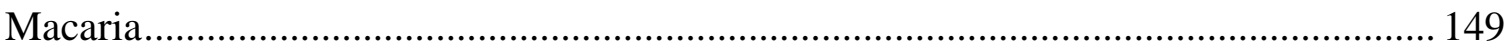

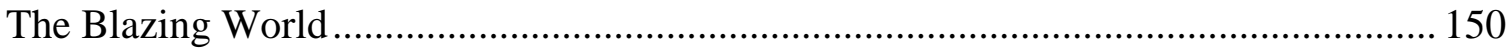

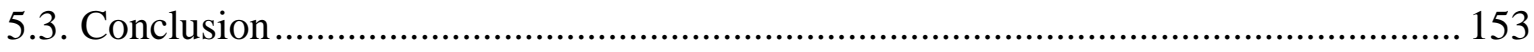

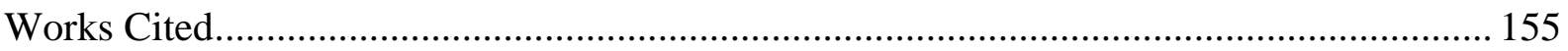

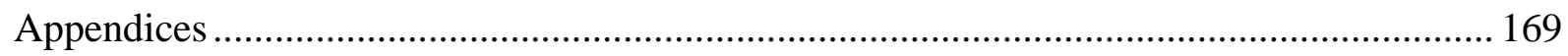

Appendix 1. Paratext nr. 3 in More's Utopia (Anemolius' hexastichon) ........................ 169

Appendix 2. The Butcher and the Poticary. An excerpt from A Pleasant Dialogue (1579)

Appendix 3. Excerpt from John Milton's An apology against a pamphlet called A modest confutation of the animadversions upon the remonstrant against Smectymnuus (1642)171 


\section{Introduction}

\subsection{Goal, corpus, compromises}

The present dissertation sets out to explore how a number of English utopian texts written in the $16^{\text {th }}$ and the early $17^{\text {th }}$ century make use of two significant formal constituents, namely the dialogic form and the paratextual elements. These two frequently recurring aspects are, in my view, always interrelated in the texts under scrutiny, and both play a pivotal role in the way the texts negotiate their own fictitious character. This basic idea reflects long-standing dilemmas of and some recent trends in utopian scholarship, but before reflecting on these, the corpus should be designated.

Although there are huge ups and down in its popularity, utopian literature is an ubiquitous phenomenon in English literature at least from 1516, the year of the

publication of Thomas More's eponymous work. The indispensable annotated bibliography compiled by one of the greatest experts on Anglo-American utopia, Lyman Tower Sargent runs to some three hundred pages, describing more than fifty works only before 1700 (Sargent 1988, 1-16). This means that in the wake of More's work such a body of utopian literature has aggregated that someone writing about utopias inevitably has to face constant compromises and exclusions, or exercise very special selection criteria. Some writers of book-length studies on utopian literature decide to take a broad chronological view, and study only the "grand utopian writers" (More, Bacon, Bellamy, Morris, Wells, Huxley, and Orwell) - or only a handful of them. Others opt for a narrower time span so that they can pay at least some attention to 
more "obscure" texts as well. ${ }^{1}$ However, since popular authors are more often discussed and in more details, this necessarily leads to constant over-representation of the big names and enduring under-representation in the case of lesser-known authors, causing huge disproportions in scholarship. ${ }^{2}$ Sargent refers to this problem in the Introduction to the first edition of his mentioned bibliography as one of the key problems haunting the study of utopias. ${ }^{3}$ In what follows, I opted for a shorter time-span (1516-1609), and tried to cover at least some of the less discussed utopias as well. The first compromise was made.

This time span obviously covers the founder (or rediscoverer/reinventor) of the genre, Thomas More, and his fundamental work, Utopia (1516), together with Francis Bacon, author of the other pivotal early modern utopia written in England, New Atlantis (c. 1624). Both works are heavily discussed in scholarship, and any of the two could overstress the structure of my dissertation due to the sheer size of related scholarship available. Here again, then, I was forced to make painful compromises. More's text,

\footnotetext{
${ }^{1}$ The dilemma is obvious and often reflected in secondary works. See for example the preface to Krishan Kumar's book (Kumar 1987), where he talks about the duality in utopian literature: grand narratives versus works on single utopias. Kumar eventually goes for $19^{\text {th }}-20^{\text {th }}$ century utopias, but feels the need to run through the whole of the tradition. Pinter reiterates the same, but for methodological reasons (develops a way of reading utopian texts and tests it on specimens of vastly different nature), his book obviously goes for the more comprehensive approach (Pintér 2010,11). Probably the best example for a more narrowly focused treatment is Davis's book, which is to be referred to later (Davis 1981).

${ }^{2}$ And the discussion of the minor texts often tends to fall down to a mere retelling of the story of the texts. An example to such a treatment is Fausett's book (Writing the New World. Imaginary Voyages and Utopias of the Great Southern Lands), which, after an intriguing introduction with many original ideas, seems to get weary at the proper discussion of the texts (Fausett 1993, for example pp. 45-48).

${ }^{3}$ I know this only from Pintér's book, who quotes the first edition of Sargent's bibliography: "most scholars have not been familiar with the »vast bulk of the literature, « only the »mainstream « of the genre." (Pintér 2010, 11). For me, only the second edition was available, where this problem or warning is not replicated, possibly because meanwhile, J. C. Davis's ground-breaking - to be mentioned later book appeared. The necessity of looking beyond the "great authors" is evident in an earlier article by Sargent: "If one is to describe a genre of literature or a literary tradition, one must move away from the "greats" and deal with the works that compose the bulk of the corpus under study (Sargent 1976, 276)."
} 
because of the dialogic form, the innumerable paratextual elements, and the constant negotiation of its own fictitious character was probably the greatest inspiration for the type of investigation I was planning to do. In fact, it was so inspiring, and the detailed look at the three intertwining aspects in Utopia proved to be so rewarding that what was originally intended to be a detailed overview of $16^{\text {th }}-17^{\text {th }}$ century English utopian corpus had to be reduced to the discussion of certain constellations within the designated period. Here I of course allude to the Manuels' famous Gargantuan monograph, where they argue for an approach which explores "historical constellations of utopias with reasonably well marked time-space perimeters and common elements that are striking enough to permit framing generalizations" (Manuel and Manuel 1979, 13). ${ }^{4}$ To some extent, my approach had to take a similar direction, as the concept of the comprehensive overview originally intended simply collapsed under the vastness of the corpus and the complexity of the questions and the individual texts themselves. This led, however, to a curious imbalance. A fundamental, case-establishing chapter is devoted to More (which work is capable of formulating probably the biggest constellation all alone, with the numerous and changing Latin editions, the protean vernacular translations, and the frequent allusions from not necessarily utopian literary works), while Bacon, sliding out from my primary time span, could only receive a brief treatment within the conclusion. This manner of handling is not meant to question the central position of Bacon's text within the corpus of early modern utopias. It was simply due to the boundaries of the project that I had to refrain from a detailed discussion of it, thereby making another inevitable and hurtful compromise.

\footnotetext{
${ }^{4}$ However, instead of the "historical constellations" mentioned in the quote, I am interested in "literaryhistorical constellations".
} 
The next restriction regarding the corpus is based on language, as I find it necessary to emphasise that I am primarily interested in English literary utopias, viz., utopias whose text is in English - either originally or in translation around the time of the original. The obvious exception here is Utopia, where I frequently had to rely on the Latin text to explore the first occurrence of the phenomena under scrutiny here. I am in complete agreement with one of the most scrupulous readers of Samuel Gott's Nova Solyma (1648), who treats this 400-page long Latin utopia as "a reminder that seventeenth-century British literature was bilingual” (Patrick 1977, 43). Patrick (1977, 44) also claims that this bilingualism was not "schizoid" at all, but still finds that "the personae adopted by such [bilingual] authors when they wrote in English differed from those they assumed when they put on the mantle of Latin". These considered, I acknowledge that in ideal case, utopias of the period should be synoptically treated notwithstanding whether they were originally written in Latin or English, all the more since some intriguing examples of a shift in language and culture are offered by these texts. ${ }^{5}$ However, I felt that because of the difference also acknowledged by Patrick, at the present stage of this project, I am simply unable to grasp both of these "overlapping but nevertheless divided and distinguished worlds" (ibid), even if this might be the ideal to follow for the (distant) future. Opening up the dissertation to such a complicated issue would simply have been an act of utter irresponsibility, and instead, a third compromise had to be made.

\footnotetext{
${ }^{5}$ This is already visible in the treatment of Utopia in its later Latin editions and its vernacular translations (discussed in more details in Chapter 2.3). Another good example may be Joseph Hall's Mundus alter et idem, published in Latin in 1605. It was translated into English in 1609 , but according to the text's $20^{\text {th }}$ century editor, this contemporary rendering is, "though enjoyable to read, might perhaps be more accurately called an adaptation" (Wands 1981b, LV). So much so that he retranslates the text from scratch. Details follow in the chapter 4.
} 


\subsection{The duality of approaches and its origins}

After so many compromises regarding the corpus, we arrive at the question of the governing aspects for my dissertation: dialogue form, paratextuality, and the use of fiction. I gradually realised that there is a need for such an approach when I repeatedly bumped into the almost complete scholarly neglect toward the formal and literary aspects of utopias, which becomes all the more conspicuous with the enduring presence of non-literary approaches. Before offering a brief overview about the long neglect and the slow turn of the tide, it is worth to look for the possible origins of the strange duality towards such texts in contemporary opinions, and in the texts themselves.

This duality is probably best exemplified by the two contradictory opinions on utopias by Milton. In a passage frequently quoted as one of the early manifestations of anti-utopian sentiment, Areopagitica (published in 1644) dismisses utopias because of their impracticality: "To sequester out of the world into Atlantick and Eutopian polities, which never can be drawn into use, will not mend our condition (Milton 1644 [1985], 219)." Yet, in a polemic pamphlet written two years earlier, Milton is writing in a different vein:

That grave and noble invention which the greatest and sublimest wits in sundry ages, Plato in Critias, and our two famous countrymen, the one in his Utopia, the other in his New Atlantis chose, I may not say as a field, but as a mighty Continent wherein to display the largenesse of their spirits by teaching this our world better and exacter things, then were yet known (...) (Milton 1641 [1953], 880-881)

Of course, the first opinion of Milton is related not to utopian literature but to impracticable political ideas, and instead of being contradictory, the two opinions simply reflect the early presence of the two sides of utopianism, which is a basic precept 
in utopian studies, one of the first things to be clarified even in introductory works. ${ }^{6}$ As for the second opinion, however, its true significance lies not only in Milton's evident enthusiasm for utopias in general and More's and Bacon's work in particular. Its governing metaphor might be even more stimulating: as Milton says, utopia is a continent where the creative mind can be unleashed to its fullest potential. The texts to be discussed here will more or less support Milton's observation, and even if sometimes we will not be convinced about the "largenesse of the spirits" of some utopia writers, it will be clear that it was in fact the geographical displacement that enabled those brave experiments with fiction. ${ }^{7}$

Tempting as it may be, this protected environment of a displaced geographical location was not used in a pure (and purely anachronistic) l'art pour l'art fashion, but it was intertwined with other extra-textual aspects. More's fundamental work (chapter 2) is not only innovative in terms of its art form, but it is at the same time renowned for its radical political-philosophical-legal concepts. The dialogic utopias around the $1580 \mathrm{~s}$ (chapter 3) use the fiction of the imaginary land, and combine it with exciting formal solutions reminiscent of Utopia, but the works are predominantly informed by harsh social criticism. Similar function can be identified in Joseph Hall's text (chapter 4), which conflates utopian fiction with the typical textual elements of early modern academic textbooks, but again with the purpose of offering a poignant satire of all aspects of social life. Gabriel Plattes (mentioned briefly in chapter 5.2) is quite explicit in the preface which is addressing the Parliament (" $[\mathrm{I}]$ have delivered my conceptions in

\footnotetext{
${ }^{6}$ See for example Sargent's warning: "One issue that regularly confuses people stems from the failure to make the distinction between utopianism as a general category and the utopia as a literary genre (Sargent 2010, 5)."

${ }^{7}$ David Fausett suggests something similar in his book exploring the ways speculation about unknown geographical regions "developed an ancient link between fiction and places that, before they became empirically known, were literally 'u-topian' (Fausett 1993, 1).
} 
a fiction, as a more mannerly way" (Plattes 1641, A2r-A2v), and it represents a pivotal turn because it uses the utopian fiction without ever trying to conceal it, signifying the way the genre gradually developed a sense of itself. Margaret Cavendish (also mentioned in Chapter 5.2) is not only first, as usually promoted, in the sense that she is the first English woman utopia writer. It is probably more important that she was among the first to express an elevated praise for the creative capacity of the utopian form in the long preface to the 1666 edition of her The Blazing World. There she calls her work a "world of my own Creating," and claims that "it is in every ones power to do the like" (Claeys 2000, 56). Looking over this group, one inevitably gets the impression that early modern English utopias appear to grow more and more self-conscious of their own fictitious nature.

The changes and dualities drafted above of course reflect how the notion of 'utopia' itself changed in the two centuries following its conception. ${ }^{8}$ Oxford English Dictionary cites the first example for the definition "[a]ny imaginary, indefinitelyremote region, country, or locality" from 1610, while the first example for the adjectival use (“'a] place, state, or condition ideally perfect in respect of politics, laws, customs, and conditions") is dated to 1613 (OED, ""Utopia, n."."2011). Nonetheless, whereas OED cites the first negative use in the sense of "an impossibly ideal scheme" from 1734 , it is obvious that in Milton's phrase ("Eutopian polities, which never can be drawn into use"), the negative overtone is already present, while in 1651, the group of texts (Plato, More, Bacon) Milton is so enthusiastic about appears in a reverse light on Hobbes' pen:

\footnotetext{
8 The broadening of the word's meaning is traced comparatively in several languages by Hölscher. His fundamental study offers a detailed overview about the semantic changes of the notion both in the realm of literature and in politics.
} 
I fear lest this writing of mine will be counted among Plato's Republic, Utopia, Atlantis, and similar mind games. ${ }^{9}$

Without a more detailed overview, these early examples hopefully showed that the duality of scholarly approaches is rooted in the early reception of the work, and the More chapter sets out to prove that Utopia's manifold ambiguity is predominantly responsible for the phenomenon. Both the ambiguity and the duality of opinions are linked to the unique role fiction plays in utopias, where it is useful to rely on Pintér, who identifies two opposing narrative demands in utopias: "the fictional credibility of the utopia on the one hand and the need for the recognition of a utopia as fiction on the other (Pintér 2010, 39, italics added)".

\subsection{Tradition, genre, literature?}

Although a sense of utopian texts forming a tradition can be reconstructed as early as 1633 (when Gabriel Naudé groups together Utopia, Campanella's City of Sun, and Hall's Mundus alter et idem), one of the first monographs to focus exclusively on the $16^{\text {th }}-17^{\text {th }}$ century English utopian tradition remarkably questions the existence of a utopian tradition. ${ }^{10}($ Hölscher 1996, 9) Davis's book defines itself as an attempt at "a serious study of the political thought of early modern utopias," and from this perspective proposes the following claim, which is of crucial importance for my dissertation:

But utopian thought itself is not a tradition in the sense outlined above. Its practitioners are not always aware of those utopian writers who have preceded them. In fact such awareness is very rare indeed. Until very

\footnotetext{
9 Thomas Hobbes' Leviathan quoted in (Hölscher 1996, 10).

${ }^{10}$ Naudé's example is related by . Awareness of tradition is also demonstrated by the fact that Hall's Mundus alter et idem was published in German as Utopia pars II, cf. Wands (1980, 1).
} 
recently utopians have not seen themselves as transmitting, extending or transforming a tradition of thought (Davis 1981, 3).

With a subtle change in terminology, the second sentence in the quotation refers not to thinkers, but to writers. Whether or not Davis's observation about utopian thought (viz. that it is not a tradition in the sense as, for example, classical republicanism is) holds true is not my concern here, since it is a question pertaining to the history of political thought. Nonetheless, when Davis talks about utopian writers not being aware of their predecessors, some confusion inevitably arises. Even if we accept Davis's claim that utopia cannot be looked upon as a "tradition of thought" (although I highly doubt this), we certainly have to allow for the existence of a utopian literary tradition. According to my reading of the same texts, the utopian writers of the sixteenthseventeenth century do have a rather apparent awareness of what was before them. In fact, the imitative techniques applied by many of them presuppose familiarity with a well-defined set of utopian conventions. In my observation, there is a certain textual tradition formulating in the early modern period, on which all the works discussed here rely, and which all of them reshape to variable extent. ${ }^{11}$

As seen, Davis's emphasis on the "political thought" of utopias led him to question the existence of a utopian tradition, even if it is not clear whether he extended his opinion on the textual tradition as well. In his approach, the fictional aspect of utopias can only receive a secondary role, an optional but at the same time useful device

\footnotetext{
${ }^{11}$ Compare this to the Manuels' following claim: "If arranged in chronological order these works, considered "proper utopias" by bibliographers, form a sequence in which the imitation of predecessors is patent (Manuel and Manuel 1979, 2)." Holstun also claims that "individual utopias form a relation of "tradition" with earlier and later utopias (Holstun 1987, 12)." More recently, Ferns reiterated the same: "To begin with, it would seem that, as a genre, utopian fiction is particularly strongly influenced by a sense of its own specific tradition - by the writer's consciousness of what has gone before. (...) Not only do writers of utopian fiction engage in an ongoing debate with the ideas of earlier writers, they are often clearly very much aware of the narrative example of their predecessors (Ferns 1999, 16-7).
} 
serving the concern "to project a total social environment" (Davis 1981, 38). The selected approach inevitably led to a partial neglect toward the fictional aspect of the works, but here, that aspect is at least registered.

However, utopian studies is often straightforwardly inimical to the literary treatment of utopias. To cite a harsher anti-literary opinion, one should turn to the sociologist Kumar, who questions the relevance of the literary facet of these texts to the extent that in his view it should not be the concern of "any serious treatment of utopia" (Kumar 1987, 25). Even Fausett, who focuses on utopian writing, expresses strong doubts about an exclusively literary approach, "because utopia was always marginal to literature, as much involved with ethnography or with politico-economic or religious theory as with literary aims" (Fausett 1993, 8). Fortunately, not only such "extremist" viewpoints can be observed in connection with these texts: for example, Holstun calls attention to their dual (textual / real) aspect, and identifies the problem that in utopian studies, in fact, two different canons have emerged - one comprising of literary utopias, the other more focusing on the social-revolutionary aspect of utopianism (Holstun 1987, 3). ${ }^{12}$

Such questions inevitably lead to the problem of the generic nature of utopias, which is addressed by several authors. Holstun, for example, emphasises the dynamic nature of the utopia genre claiming that its history is in fact the history "of the very

\footnotetext{
12 James Holstun clarifies at the outset of his book that "[p]uritan utopia is a literary form, political rhetoric, and social practice." It is also he who calls attention to the duality of utopian canons (Holstun 1987, 11). Something similar can be witnessed in Chordas' vague but consistent use of the term 'extrafictional' in warnings like this: "it is well to remember that utopia in the early modern period has a well-documented career in the real, extrafictional world (Chordas 2010, 1)". Of course, this alreadyreferred-to duality has long been registered in scholarship, and it is as old as the genre itself: as we will see, the first readers of Utopia, the writers of the letters published with the text are already aware of it.
} 
changes in its relations with other genres" (Holstun 1987, 13). The question of genre is equally prominent in Fern's book, where he calls attention to the peculiar generic status of More's Utopia, which, according to him, cannot be treated as a utopia proper, since at the time of its birth, the genre was not yet in existence (Ferns 1999, 31-2). ${ }^{13}$ In Kendrick's book, genre is so relevant that the opening chapter offers general observations concerning the notion of genre, starting out from the observation that specific genres are often associated with specific historical periods, and calling attention to the dynamic-dialectic relationship between the two (Kendrick 2004, 3-5). Chordas goes as far as to claim that utopias are „comprised not in fact of one single, unified genre, but rather of a conglomeration of genres, or forms, not all of them usually considered fictional" (Chordas 2010, 6). One member of this conglomeration, according to her classification, is dialogue.

As seen, many scholars find it useful to link utopias to different genres, which might tempt one to set sail on dangerous waters. A common feature of the texts we are dealing with (that they use a fictitious geographical location with the purpose of social criticism) is a feature shared with Defoe's Robinson Crusoe, and Swift's Gulliver's travels as well. Both novels are swarming with the conventional narrative elements of utopias. ${ }^{14}$ In my opinion, some aspects of early modern English utopias are not that far from "proper" novels, and this obviously has to do with the different ways they experiment with fiction, using utopian spaces literally as the cited Miltonian continent where the spirit of the author can freely roam. As if utopian space could have served as

\footnotetext{
${ }^{13}$ With reference to Darko Suvin, Gary Saul Morson and Tom Moylan, Ferns' account also emphasises the need to break away from a static notion of utopia. Cf. Ferns (1999, x).

14 On Robinson Crusoe and utopia, see Hongying (2007), and the chapter on "Robinson and the Robinsonades" in the Manuels' book Manuel and Manuel (1979, 433-4). For a more extensive treatment, also recounting the history of the genre before Defoe, see (Reckwitz 1976), especially the chapter "Utopie und Robinsonade" (pp. 136-146). In connection with utopia and Gulliver's Travels, see Houston (2007).
} 
a secure sandbox (to borrow a term from computer programming), where the possibilities of imagination, fancy and fiction could be tested to their very limits within a protected environment.

With this far-fetched observation, however, I would not like to suggest that the novel has grown out of the utopia, as it would open up a huge surface for - legitimate and with all probability, extremely fervent - attacks. The question of the emergence of the novel (some would already criticise my use of the word 'emergence' here) is an inextricably complicated question, and I try to avoid it in my work by all means. ${ }^{15} \mathrm{I}$ would only like to suggest that early modern English utopias might have more in common with novels and especially with other related literary genres and »precedents« (for example, prose fiction, romances, or women's amatory fiction etc.) than usually acknowledged. ${ }^{16}$

\subsection{Pro-literary opinions}

After recounting so many opinions sceptical about a literary approach to utopias, this claim might seem ill placed. Fortunately, from time to time, pro-literary positions surface within the predominantly contra-literary realm of utopian studies. Mention must be made about C. S. Lewis' evaluation of Utopia in his literary history, where he harshly questions whether it is appropriate to read the text as a philosophical tract.

\footnotetext{
${ }^{15}$ The question of the emergence of the novel is still haunted by the ghost of Ian Watt's monograph. For a good summary of the so-called Watt-theses and an overview of its criticism, see Hammond and Regan (2006, 1-29).

${ }^{16}$ To give a rather practical example: one of the texts to be discussed, Hall's Mundus alter et idem was published in a later plagiarised version with the word 'novel' typographically emphasised on its title page (Quevedo 1684). A less direct example would be the Robinsonade-like part of Francis Godwin's Man in the Moone (1638). There the protagonist must live for a certain time on almost completely deserted island, where the other inhabitant is a black man, a situation fairly similar to that of Robinson Crusoe (find the episode in Godwin 2009, 74-78).
} 
Relying on contemporary opinions (Erasmus, Tyndale, Harpsfield), he arrives at the following conclusion:

It all sounds as if we had to do with a book whose real place is not in the history of political thought so much as in that of fiction and satire (Lewis 1954, 167).

Later, Northop Frye also linked the text to a tradition vastly different from political thought. In the fourth essay of Anatomy of Criticism, an interesting comparison (and distinction) is made between novels and texts like Gulliver's Travels, Candide or Brave New World, which Frye classifies under the label 'Mennipean satire', one subtype of which is utopia (Frye 1990 [1957], 308-9). In his later essay, Varieties of Literary Utopias, utopia is interpreted within the framework of myth criticism, forming a diametrical opposite of social contract, a speculative myth that "belongs primarily to fiction (Frye 1967 [1965], 25)". He also claims that the relative rationality offered by utopia "is the result of using certain literary conventions," one of these being the dialogue between a guide and the narrator (Frye 1967 [1965], 26).

In both of Frye's essays, satire is closely related to utopia, and it is basically this thread that Elliott takes up a few years later, fuelled by a strong criticism against the overtly catholic interpretations of More. In fact, he is so much against readings that try to get Utopia and catholic teachings in line that he desperately call for another kind of approach:

Clearly we need, not the Catholic or the Marxist or the city- planner interpretation of Utopia, so much as we need an interpretation that will tell us what Utopia is, that will place it with respect to the literary conventions which give it form and control its meaning. ... Utopia has the feel-the form-of satire (Elliott 1963, 320). 
His reading of Utopia significantly makes use of some of the paratextual materials (Erasmus' and Busleyden's letters), refers to the famous controversy between Erasmus, More, and Martin Dorp, and shows parallels between Utopia and Roman verse satirists (Elliott 1963, 317-334). Elliott does not simply highlight the influence of satire on utopia, but he importantly identifies specific similarities. The same analysis is complemented in his later book with a whole chapter on the connections between Saturnalia, satire, and Utopia, which explores the link between ancient concepts of Golden Age and modern utopias, suggesting that their intersection is the Saturnalia:

The genetic relation of the two modes [utopia, satire], however, derives from the sanctioned license of the holiday. (Elliott 1970, 16)

For a long time, these literary interpretations gained little currency. According to Pintér's detailed historiography of utopian studies, the reason for this was the advancement of neo-Marxist approaches in the 1970s-1980s (Pintér 2010, 25). As we saw above, an interest towards the generic status of utopia can be traced in more recent works, too, but these regularly focus not so much on the literary relevance but on the social dynamics of genres. ${ }^{17}$

Pintér's book (The Anatomy of Utopia. Narration, Estrangement and Ambiguity in More, Wells, Huxley and Clarke), published in 2010, is among the very few books on utopias that utilises an exclusively literary approach, treating utopias as literaryintellectual games instead of political propositions. ${ }^{18}$ Some will necessarily find such a

\footnotetext{
${ }^{17}$ Holstun's remark is telling: "[this study will] look for the ways in which the formal traits of utopian writing (literary and nonliterary) and its exercise of power imply each other" (Holstun 1987, 10). In the same year, Kumar claims that the fact that Utopia gave birth to a new genre is unimportant even if the form was unprecedented in his times (Kumar 1987, 24).

${ }^{18}$ It must be immediately noted that Pintér's literary approach is on one of the poles, and examples from the other could easily be cited from recent scholarly output. In fact, utopian studies seem to accurately reflect the original ambiguity of More's work ever since.
} 
one-dimensional approach insufficient, and even despite my unquestioned support of it, I find it simply inoperative in the case of some of the texts I will discuss (and which I still consider "proper" utopias). Nonetheless, in many instances, my impressions about early modern utopian texts coincided with Pintér's statements, and it was this literaryfocused treatment that gave me the final push to undertake the project with the sort of approach I had in mind. Not necessarily with its specific details but more with its general stance, Pintér's book supports the idea that the literary and textual aspects in early modern utopias represent a legitimate area of research. Another support for such an approach is Chordas, who, though more interested in the non-fictional (or "quasifictional") generic affiliations of utopias, also calls attention to the unique status of fiction in them:

Yet even in its fictional incarnations, utopia as an articulation of the ideal society is made up of sub-genres, usually conducted in prose, whose status as not-fiction (or quasi-fiction) in turn allows utopia to carry a weight not usually accorded to fiction.

\subsection{Dialogue form and paratextuality}

The cited perspectives gradually drove me toward an approach which focuses on the literary aspect of utopias, and I was especially interested in the way these texts reflect upon their own fictitious nature. Insights from scholarly literature about the generic nature of utopias, together with a detailed look at More's text convinced me that there are at least two aspects providing fruitful reflections upon these questions. The first is the role of the dialogue form in early modern utopias, since the form is present already at the birth of the genre and comes back in varying degrees and in different roles later. The crossover (fiction-nonfiction) nature of the dialogue form is a longestablished opinion in scholarship, and I am convinced that there is a strong interaction 
between fiction and dialogue in utopias. ${ }^{19}$ The other key location to the understanding of the working of fiction is the paratextual environment. ${ }^{20}$

As for the first aspect, the dialogue form, it is in itself a remarkable problem in English literary history. Although several hundreds of dialogues are known from the $16^{\text {th }}-17$ th century, secondary literature has for a long time done little besides registering the popularity of the genre. ${ }^{21}$ Even if the situation has been partially ameliorated since, Deitch's dire summary of secondary literature about early modern English dialogues still holds true:

Awareness of dialogue literature today in either medieval or Renaissance studies is extremely low, with many scholars not even bothering to register the form of the dialogue works they have read. Among specialists on dialogue, divided by widely differing national traditions, consensus is lacking and discussion is too isolated and sporadic to even establish basic premisses, even though independently there is a certain amount of agreement (Deitch 1998, xi). ${ }^{22}$

As this dissertation sets out to demonstrate, this historiographical problem is closely related to utopian studies. A profound impact of Renaissance dialogues can be

${ }^{19}$ Wilson traces back this ambiguity to the ancient precedents, claiming that in the Aristotelian system, dialogue is "a partial imitation, and hence a medial art: an incomplete fiction" (Wilson 1985, 9). In Chordas opinion, dialogue "is a form in its own right, occupying a middle ground between ordinary conversation and oratory, as well as between fiction and nonfiction," a feature allegedly shared with utopias (Chordas 2010, 21).

${ }^{20}$ As for a definition of paratext, there is not much else to rely on than Genette's description, who calls the "accompanying productions" surrounding the text paratexts. He also uses the term epitext, referring to accompanying productions which are outside the material vehicle of the given text (which are outside the physical book), but when I use the term, I mean it principally as the accompanying material within the book. Cf. Genette (1997, 1-3).

${ }^{21}$ I have compiled a bibliography of dialogues published until 1600 with the help of Early English Books Online, and it yielded 240 results, which is, in proportions at least, in accordance with secondary literature. For example, Deitch talks about 300 dialogues between 1559 and 1603, out of which, 150 were first published in the period (Deitch 1999, 47). A search in the online Short Title Catalogue returned 333 hits until 1600 on the title query "dialog".

${ }^{22}$ A more detailed account of the problem follows in Chapter 3. 
observed in Utopia, and the use of the form is inevitably due to its peculiar go-between (fiction-nonfiction) nature. However, not only a lack of consensus but even the lack of a fluent dialogue between different fields (dialogue studies, utopian studies, More studies) has so far hindered a proper exploration of the following questions:

1) What role did the dialogue form play in More's Utopia, and how it is related to the ambiguity of the work and the mentioned duality of interpretations (chapter 2)?

2) To what extent was this feature of the original pattern followed by the first English imitators of Utopia (chapter 3)?

3) In what new and transformed ways did the dialogue form exert its influence in the subsequent generations of the evolving utopian tradition (chapter 4 and $5) ?$

As for the second aspect, More's text, like many later utopias, is surrounded by different kinds of textual and figurative elements, which are not part of the main text itself. Despite their seemingly marginal position, the role of these elements is decisive, and they may serve as the perfect illustration for the central claim of the most thorough theorist of paratextuality, Genette:

Indeed, this fringe, always the conveyor of a commentary that is authorial or more or less legitimated by the author, constitutes a zone between text and off-text, a zone not only of transition but also of transaction: a privileged place of a pragmatics and a strategy, of an influence on the public, an influence that - whether well or poorly understood and achieved - is at the service of a better reception for the text and a more pertinent reading of it (more pertinent, of course, in the eyes of the author and his allies) (Genette 1997, 2). 
Utopia is an extreme example for the application of paratexts: there are no less than 16 paratextual elements in the March 1518 Basel edition, which makes it as much of a symbol for the prefatory conventions emerging in the wake of printing as are Rabelais' prefaces (Genette 1997, 169-70). This abundance shows that the text's publishers had a very strong intention to control the reader's experience, so it is undoubtedly the place to look for interpretive, self-reflexive clues. ${ }^{23}$

In fact, the role of this liminal zone is so important in early modern utopias that among the texts I discuss, even the shortest, sixteen-page-long work (Plattes) contains a preface, and I cannot name one without at least one short prefatory note. Albeit the majority of later utopias cannot match the paratextual opulence of Utopia, the prefaces and other ancillary materials play an important role in them as well. It is conventionally the place where such works reflect upon their own fictitious nature, which was probably necessitated by the ancient suspicion against travellers' tale. ${ }^{24}$ Yet in the most exciting cases, they exploit the unique communicational situation of the preface, and they carefully linger on the verge of reality and fiction. ${ }^{25}$ Easy to see, such reflections are capable of profoundly influencing the contemporary readings of the text, while enriching its present-day interpretations at the same time. Key terms (fancy, fiction,

\footnotetext{
23 The unique paratextual configuration of Utopia made it a perfect subject of study for a project on cultural transfer (Disclocations: Practices of Cultural Transfer in the Early Modern Period). Referred to in the chapter on More.

${ }^{24}$ The debate or at least a rumination on the truthfulness of the traveller's story in the prefatorial position is almost always found in utopias, and it might be traced back to "proto-prefatory" examples as early as Lucian's True History. In Genette's concept, printing brought the stabilisation of prefaces, which were before incorporated in the text. He quotes numerous classical references in support of this claim, among them, Lucian. See Genette (1997, 163-5).

${ }^{25}$ Genette's detailed typology of paratexts devotes a complete chapter to the "prefatorial situation of communication". In utopias, the most exciting prefaces are probably those which address a real person on behalf of the fictitious narrator of a given text, blending the distinction between what is in the text and what is outside it (see for example A pleasant dialogue by a Lady called Listra in chapter 3).
} 
imagination), authorial role-playing, author-reader/narrator-reader and other types of dialogues - all come down to us via this paratextual channel, and a systematic study of them will inevitably lead us to a better understanding of utopia as a literary form.

The general aim of my dissertation is then to prove that the formal features (dialogue form, paratextual materials) of utopias are no less important in the development of the tradition than conventions related to the content. A better understanding of these features will hopefully contribute to a better understanding of the genre as a whole, while at the same time it will probably produce results that reach beyond the corpus under scrutiny here.

Finally a few words about the structure of the dissertation. It commences with a lengthy chapter on Thomas More's Utopia, where I investigate the role the dialogue form played in the text, followed by a detailed discussion of the prefatory material, complemented with observations concerning the paratexts in the German and the English translations. In fact, this chapter serves as a case study for the rest of the dissertation, where the applicability of the selected approach will be measured. More is beyond question the best subject for such a case study due to the immense quantity of relevant secondary literature. Concentrating mainly on one text, the second chapter explores the unique Elizabethan utopian-dialogic constellation which can be observed around the 1580s, and which signals a renewed interest towards Utopia with the explicit aim of imitating it. Parallel with the move to English texts, this chapter will introduce the reader to the curious place of Renaissance dialogue in English literary history. This will be followed by a chapter on Joseph Hall's Mundus alter et idem, which was originally written in Latin, and explicitly regards More's text as a pattern, but was also 
influenced by some achievements of more recent English specimens. The concluding chapter offers an overview of the results, but it also tries to take but a preliminary look at some works which have been left: in connection with Francis Bacon's New Atlantins, Gabriel Plattes' Macaria, and Margaret Cavendish's The Blazing World, I can only offer sketches to the examined aspects, with the hope of opening up areas for further research. A concluding subchapter concisely summarises the results gained from the investigation. 


\title{
2. The dialogic roots of utopia: Thomas More's Utopia $(1516)^{26}$
}

\author{
In 2009, A Companion to Thomas More (edited by A. D. Cousins and Damian Grace)
}

was published. The volume offers a comprehensive overview about the life and works

of More, and in its introduction, Utopia is praised with the following words:

Macchiavelli's Prince and More's Utopia are the two great books that inaugurate modern political theory. Neither author could have foreseen how dramatically his ideas would shape modern conceptions of politics. (Cousins and Grace 2009, 15)

Utopia is represented here as one of the Herculean pillars of modern political thinking and its author is considered more of a politico-philosopher than a writer. The juxtaposition of Utopia and the Prince is a recurrent theme in scholarship, and it is significant in more than one ways. ${ }^{27}$ In the first place, it puts More's text on the pedestal of political theory, since Machiavelli's book is probably the single most important

\footnotetext{
${ }^{26}$ More than any other part of my thesis, this chapter presupposes a strong familiarity with the text under discussion. The reason for this is not only the fact that More's text is the most popular of my corpus, but it is also a means of addressing the challenge to keep the length of the chapter at a reasonable length. This is also the reason why I could not give a satisfactory account of the vast literature on either More or Utopia, although I hope that at least some more important opinions and principal trends will duly surface from my account.

${ }^{27}$ In the introduction to the Yale edition, the section devoted by Hexter to the unrestrained praise of Utopia as a "vision" that More wrote in "moments of acute perception which took possession of him," More, the writer of Utopia is compared to Machiavelli, the writer of The Prince. Both men are achieving "unique heights" in these works, as opposed to their more ordinary other works (CW 4, xxvi-xxvii). See also Hexter's "The Loom of Language and the Fabric of Imperatives: The Case of Il Principe and Utopia," American Historical Review 69 (1964): 945-68. The doyen of the history of political thought, Quentin Skinner considers Machiavelli and More the two most important Renaissance political thinkers in his The Foundations of Modern Political Thought (Vol. 1. The Renaisssance). Already the title page of some of the editions represent this, as they consist of Santi di Tito's famous portrait of Machiavelli and the no less famous painting of More by Hans Holbein the Younger. See Skinner (1978 [1994], esp. pp. 180-186, 255-262). A somewhat more recent example is the Fortiers' book, which suggests a strong politico-philosophical opposition between Utopia and The Prince, the former representing humanistic utopianism, while the latter is seen pointedly as "the most important source of the anti-utopian countermovement in the world" (Fortier and Fortier 1992, iii). For more references on the same, see items 519532 in the bibliography compiled by Lakowski: "A Bibliography of Thomas More's Utopia." Early Modern Literary Studies 1.2 (1995): 6.1-10. URL: http://purl.oclc.org/emls/01-2/lakomore.html.
} 
political treatise of the time. In the second place, the fact that such a comprehensive monograph, aiming at an overview, singles out this aspect of the work is strange. As we will see, many critics of Utopia have argued against the "exclusivist" (or "black-andwhite") reading of the text, yet Utopia as a literary work and Utopia as the vehicle of certain political concepts are still regularly treated in complete separation. Two wellknown extremes of these exclusivist approaches are Karl Kautsky and C. S. Lewis: while the former reads the text as a social blueprint, the latter argues that in order to appreciate Utopia, we should read it as what it was intended to be: a holiday text, a mere jeux d'esprit. ${ }^{28}$ The present chapter tries to keep in mind and warn the reader about this exclusivity. However, in view of the dominance of political-ideologicalphilosophical approaches (that is, approaches focusing on the content) to the text, and because of the purposes of this dissertation, it swings to the other end, and instead of the different »extratextual« contexts, it pays more attention to the literary and paratextual context of Utopia. In particular, I set out to demonstrate the strong influence of the literary tradition of Renaissance dialogues on the text, while on the other hand, I argue that the due consideration of the constantly shifting paratextual environment of the text (the different letters, illustrations, poems) is key to the understanding of Utopia.

As for the background of my work, it is deeply inspired by a survey of More studies which was done in the early 1990s by Romuald Ian Lakowski. Many insights of his dissertation (Sir Thomas More and the Art of Dialogue) were seminal for the arguments that I develop here, although in more than one instance, I could not completely agree with him, or found that his intriguing questions yield fewer answers

\footnotetext{
${ }^{28}$ Under "exclusivist", I mean readings which attempt to treat it either as a literary game, or as a serious political tract. In my opinion the work's inherent ambiguity denies an either/or approach, but this opinion, as we will see in some of the opinions to be quoted here, is nothing new.
} 
than expected. Nonetheless, my growing interest in the connection between the dialogic form and the genre of utopia was fundamentally reinforced by his work, and I was in complete agreement with him that "The brilliance of More's literary artistry in Book I has been seriously underestimated," even if there are important exceptions to this generalisation (Lakowski 1993, 89 [23]). ${ }^{29}$ However, I think it is not enough to stress the "brilliance" of More in connection with Book I, but also the fact that together with the often neglected prefatory materials, it consists an organic part of the work as a whole. According to Lakowski's reckoning, the balance of the scholarship in this regard is worrying: $80-85 \%$ of the scholarship available on Utopia up to the 1990s focuses exclusively on Book II (Lakowski 1993, 89 [27]). In the present chapter, Lakowski's call for a structural analysis of More's works will be followed, and expanded with some more recent results of scholarship.

I begin with a short survey of the material conditions of the text's first Latin editions. Then I move on to explore the role of the Renaissance dialogue tradition in the work, with some issues concerning the standard critical edition of the work, and then move on to investigate the prefatory materials, searching especially for passages dealing with the theme of literary theory, representation, or fictitiousness. Finally, I take a brief glance at the transmission of the text into different vernaculars in the sixteenth century, with specific focus on the German and the English translations. I argue that in order to grasp some of the most important aspects of More's work, one must always keep in mind the ancillary matters. To prove my point, I also briefly examine the fate of ancillary material in some $16^{\text {th }}$ century translations of the text, trying to establish how

\footnotetext{
${ }^{29}$ Lakowski's thesis is available on the internet in a carefully edited online version. The edition preserves the page numbers, and I use these for reference, but between square brackets, I also include the paragraph number provided in the online version.
} 
the modification of the paratextual environment reconfigures the shifts and balances in the work. The case of the English translation will receive particular attention not simply as the translation of a Latin text into English, but also as the foundation of a specifically English genre. With the help of references from contemporary literary works and poetic treatises, I demonstrate that in a few decades this gradually solidifying genre gained enormous popularity in Elizabethan literature. The formal analysis will be concluded by an evaluation of the findings in the light of various recent trends in the study of Utopia. I argue on one hand that More's text closely follows the model of the dialogue as established by Renaissance theory and practice, while on the other hand, I set out to explore a less evident strain of self-reflective literary-theoretical ideas in the paratextual material. My results will be contrasted with suggestions that the fictional authentication and authorisation applied in the work evolve from the implications of the new medium, the printed book, and I refer briefly to the question of textual variance.

\subsection{Textual Introduction}

A thorough look at some aspects of the early textual history of Utopia is indispensable not only because of my emphasis on the formal aspects of the work, but also because a number of new research tools have become available recently. ${ }^{30}$ For the present perspective, the most important one is the Disclocations: Practices of Cultural Transfer in the Early Modern Period (University of Toronto) project. More's work served as the guinea-pig for this enterprise, illustrating the importance paratextual elements possessed in the early modern era:

\footnotetext{
${ }^{30}$ A small note must be added here as for my use of translations. In most cases, I rely on the Yale edition, as conventional (and often problematic) in scholarship. However, I often found the newer translation (More 1995) more accurate. That the translation of the prominent Yale edition is highly problematic has been highlighted by no less reviewer than Quentin Skinner, see Skinner (1967).
} 
The Utopia subproject (...) shows, for example, that a detailed and systematic study of the paratexts of translations of a single work can provide important information not only about its textual character but also about its historical, ideological and aesthetic positioning. ${ }^{31}$

In 2008, the research group published a volume containing articles about both the early modern Latin editions and the vernacular translations of More's work, as well as the paratexts pertaining to the vernacular translations. Obviously, this exciting new opportunity to take a synoptic view at the paratexts in the different versions of the work provides important insights into the relationship between Book I, Book II and all the rest of the dedicatory poems, letters, maps and other materials originally published together with the work. Nevertheless, everything originates from the Latin versions published in More's time, so any textual overview of Utopia must begin with these. ${ }^{32}$

The year conventionally associated with Utopia is 1516 , when the first edition of the work was published in Louvain. However, this was only the foremost out of the five editions that quickly followed each other. The following table offers a brief overview of the first Latin editions:

\begin{tabular}{|llll|}
\hline YEAR & PLACE & PRINTER & PARATEXTUAL ELEMENTS \\
\hline $\mathbf{1 5 1 6}$ & Louvain & Martens & $\mathbf{1 3}$ \\
\hline $\mathbf{1 5 1 7}$ & Paris & Gourmont & $\mathbf{1 3}$ \\
\hline $\mathbf{1 5 1 8}$ March & Basel & Froben & $\begin{array}{l}\mathbf{1 5} \\
(+ \text { epigrams by More \& Erasmus })\end{array}$ \\
\hline $\mathbf{1 5 1 8}$ Nov & Basel & Froben & $\begin{array}{l}\mathbf{1 4} \\
(+ \text { epigrams by More \& Erasmus })\end{array}$ \\
\hline $\mathbf{1 5 1 9}$ & Florence & Giunta & $\mathbf{8}$ \\
\hline
\end{tabular}

${ }^{31}$ From the project description available at http://www.ub.uio.no/fag/spraklitteratur/romansk/prosjekter/dislocations/tekster/prosjek.pdf. Date of access: 02 Oct 2012.

${ }^{32}$ In introducing the Latin editions, I rely on the bibliography chapter of the Yale edition (CW 4, Part III). 
Table 1. Contemporary Latin editions of Utopia $^{33}$

The highlighted edition, printed in Johannus Froben's press in March 1518 is usually regarded as the most authentic one, based on the assumption that it is the last to which More had probably still contributed ( $\mathrm{CW} \mathrm{4,} \mathrm{clxxxvii);} \mathrm{this} \mathrm{is} \mathrm{also} \mathrm{the} \mathrm{one} \mathrm{with} \mathrm{the}$ highest number of ancillary materials. ${ }^{34}$

The correspondence related to the process of the publication is primarily concerned with securing the array of prefatory letters, and confirms that the book "was a corporate product of Erasmus' humanist circle" (More 1995, 276). In one often-quoted exchange by the two friends, More is asking for recommendations not only from scholars, but also from statesmen, a remark which obviously has some bearing on the interpretation of the work. ${ }^{35}$ In terms of changes, the subsequent editions are preoccupied with the number and the order of the materials surrounding the base text. It is also significant, and largely ignored, that in three out of the five editions, More's work is published together with other literary works: in two instances, it is paired with More's and Erasmus's epigrams, while in the edition of 1519, it is followed by translations of Lucian by More and Erasmus. This means that most of the editions are in fact not simply editions of Utopia, but they are joint publications by More and Erasmus,

\footnotetext{
${ }^{33}$ Numbers in the last column are based on (Cave 2008, 278). It must be noted that the tables offered in the book do not include the title page, so if we treat them as part of the paratextual construct, then (at least) 1 should be added to the numbers in the last column. For Genette, the paratext is obviously important, so much so that he discusses it divided into two: the author's name and the title. See chs. 3-4 in (Genette 1997).

${ }^{34}$ However, the assumption is not generally accepted. For example A. E. Barker's claims that "there is thus no convincing collateral evidence for regarding the 1518 text as having any special authorial, as distinct from editorial, weight" (Barker 1966, 322). The 1518 March edition of Froben seems to have kept its authority among editors, nothwithstanding the extent of authorial role involved.

${ }^{35}$ See CW 4, (clxxxiii). Grace interprets this as a sign that for More the work was "serious political theory, not just an imaginative and satiric treatment of the human condition (Cousins and Grace 2009, 179)". He positions this opinion against that of C. S. Lewis and R. Marius.
} 
yet another textual monument for their legendary friendship. ${ }^{36}$ The collective nature of the publications and the overabundance of the paratextual material (together with More's mentioned remark) suggest that the humanist "corporation" behind the enterprise had a strong desire to mediate between the readers and the text. It is also clear that Utopia was at least to some extent the part of a larger intellectual project (out of the first five editions, it was twice published together with Erasmus' epigrams, and once with Lucianic translations of the two), a fact that the sui generis character of the work, praised ever so much by readers of all times, unfortunately conceals.

Talking about the early editions, the original full title of the work calls for some important remarks. One editor of the Yale edition argues that it is rather misleading that the work is nowadays commonly referred to as Utopia, suggesting The Best Order of Society as a more appropriate short title. ${ }^{37}$ Indeed the original title is much more complex, and the conventionally used short version conceals many important generic affiliations of the text:

De optimo reipublicae statu deque nova insula Utopia libellus vere aureus, nec minus salutaris quam festivus, clarissimi disertissimique viri Thomae Mori inclutae civitatis Londinensis civis et Vicecomitis.

\author{
On The Best State of a Commonwealth \\ and on the New Island of Utopia. A \\ Truly Golden Little Book, No Less \\ Beneficial than Entertaining, by the \\ Most Distinguished and Eloquent \\ Author THOMAS MORE Citizen and \\ Undersheriff of the Famous City of
}

\footnotetext{
${ }^{36}$ For a brief introduction to the epigrams of More and Erasmus, see Miller's chapter in (Cousins and Grace 2009, 127-144). In Miller's opinion, the epigrams and the earlier Lucian translations comprise a literary diptych, verbal counterparts to Quentin Metsys's famous diptych of Erasmus and Giles (127).

${ }^{37} \mathrm{Cf}$. CW 4 (cxxv, note 1). Of course, the volume itself refers to the work as Utopia, Surtz's remark is theoretical in nature.
} 
London. ${ }^{38}$

The first part of the full title ("On the Best state of a Commonwealth") immediately evokes the tradition of "ideal society literature" in general and Plato's Republic in particular. ${ }^{39}$ This link is useful for those who set out to examine the book or the genre for its content, yet the duality revealed by the phrase "No Less Beneficial than Entertaining" is an important check on this aspect. The book was not only an attempt at describing the ideal state, its dedicated purpose was also to entertain the reader, an objective further reinforced in the fifth edition, where Utopia is enclosed with translations of Lucianic dialogues.

At the same time, the use of the Latin term "festivus" establishes an interesting link with the dialogue genre. In his 1987 article, the historian Peter Burke claims that besides other causes (like the impact of printing and the rise of rhetoric), the dialogue was so important in the Renaissance because it was perfectly able to simultaneously encapsulate the serious and the comic elements in the tradition of the Greek spoudogeloios (Burke 1989, 8). Burke argues that the word festivi or festivissimi appear on the title page of dialogues to "advertise the product or warn the literal-minded reader

\footnotetext{
${ }^{38}$ Original title from the Yale Edition, double-checked against the online version of the Basel 1518 edition (More 1518 [online]). Translation from (More 1995, 3).

${ }^{39}$ The term "ideal society literature" is among many others employed by Davis, who treats utopia as one subtype of this more general category (the others being arcadia, perfect moral commonwealth, land of cokaygne and millennium). Although Davis acknowledges that these do not tend to appear in separation, I find that he is far too categorical in his classification. To give only one example, he rejects to treat Joseph Hall's Mundus alter et idem as a proper utopia, which is strange if we consider that the German translation calls Hall's work Utopia pars 2, and that there was an edition in which Hall's work was published alongside More's work and Campanella's City of the Sun (more details follow in the Chapter 4). Cf. Davis (1981, 20-22)
} 
not to take the text too seriously (ibid.). ${ }^{, 40}$ That the question was on the agenda of humanists around the time of Utopia's publication is demonstrated by one of the most famous contemporary elaborations on the topic of mixing the comic and the serious element: Erasmus' preface to the Praise of Folly, addressed precisely to More, published only five years before Utopia. Here Erasmus argues that foolery can be handled in such a way that the "reader ... may reap more benefit from it than from some man's crabbish and specious arguments (Erasmus 2008, 5)". The dual purpose of seriousness and lightness should always be kept in mind when dealing with Utopia, as Erasmus' work is quite close to More's in tone and in time as well, not to talk about their legendary friendship. ${ }^{41}$

\subsection{The utopian model of More}

It is always a huge challenge to pinpoint the beginnings of a genre, and the proposed answer tends to become vaguely metaphoric. 'Rise' is probably the most popular - and most fervently contested - of these metaphoric keywords, but critics occasionally venture as far as to compare this emergence to a scene from a horror movie where the mummy emerges from the surrounding mud, "at first and for some time indistinguishable from the mud that is its element (Hammond and Regan 2006, 16).” In

\footnotetext{
${ }^{40}$ It might have some relevance that next to one of the more entertaining episodes (the word-fight between the friar and the fool) from book I, we read the following comment on the margin: "Festiuus dialogus fratris \& morionis [A Merry Dialogue between a Friar and a Hanger-on]" (More, Surtz and Martz 1965, 80-1).

${ }^{41}$ Among others, R. J. Schoeck also warns about the implications of the complete title, and he does so in an article arguing for a less black-and-white, more open approach to the work, which recognises the simultaneous presence of utile et dulce. Cf. Schoeck (1969, esp. 27-28). About the relationship between the topical friendship between humanists and the dialogue form, see Vallée (2004, 42-62), who claims that Utopia is the best work to explore the mutual interdependence of the two. The close relationship between The Praise of Folly and Utopia is a commonplace in More studies, with the classic example being Surtz's Praise of Pleasure and Praise of Wisdom.
} 
the case of utopias, one could initially assume a fairly advantageous position because of the very name of the genre. Since the word 'utopia' is an invention by Thomas More, it seems that we have a de facto date for the "emergence" of the genre. In an admittedly provocative way, however, in the present subchapter I am going to argue that even if Thomas More's Utopia gave the name for a genre (which was, at least partially, already existent by that time), the work itself was not at all intended to be what later become known as utopia. In order to prove this, I perform a detailed structural analysis of the work, and in accordance with my previous assumptions, work means here not only the two books, but also the many different paratextual elements surrounding it. There is a great distance between the genre denoted by the word 'utopia' and Utopia, and here I will suggest that this distance is rooted in the structure of the work.

\section{The dialogic nature of Utopia}

In a rather characteristic way, the Yale edition of Utopia begins with a chapter by J. H. Hexter entitled The Composition of Utopia. These very first pages of the introduction dwell on the accurate dating of the work. Reiterating some of the ideas already published in his More's Utopia: The Biography of an Idea, Hexter argues that most of Book I was written after Book II, and he tries to prove this by pointing out a supposed opening or break in the structure of Book II (CW 4, xv-xxiii). ${ }^{42}$ Yet, as Grace put it four decades later, "that opening is increasingly hard to see (Cousins and Grace 2009, 187)." Nonetheless, Hexter's reading, so closely related to the structure of the work, placed in such a prominent position, certainly had a strong impact, and it might have played a role

\footnotetext{
${ }^{42} \mathrm{Cf}$. CW (4, 52-55). The narrator here claims that he omits a lot from Hythloday's "long tale" about the places he saw, and restricts himself to what he told about the customs of the Utopians, "first, however, giving the talk which drew and led him on to mention that commonwealth." In Hexter's opinion, this latter argument for the rest of Book I is artificial. In my opinion, it is artificial only to the extent one is convinced about Hexter's reconstruction of the genesis of the work, which is plagued by chronological inconsistencies and a sense of teleology.
} 
in the already noted problem of proportions in studies on the work, as Lakowski identified it in the 1990s. Hexter's insights had the probably unintended effect of a value judgment on later readers: Book 2 achieved superiority as something more spontaneous, while through Hexter's eyes, Book II became a subsequently inserted, thus less integral part of the whole, with a more pragmatic, less aesthetic purpose, in fact, a mere piggy-backer attached to Book 2 .

As the basis for a re-evaluation of the structure of the work, let me remind here the reader on Hexter's model in the order of composition:

$\begin{array}{ll}\text { Book I } & \text { Introduction } \\ \text { Book II } & \text { Discourse on Utopia } \\ \text { Book I } & \text { Dialogue of Counsel including the Exordium } \\ \text { Book II } & \text { Peroration and Conclusion }\end{array}$

However, Hexter's model has later been increasingly questioned, particularly because of its complete disregard for the fictional aspect of the work: he goes as far as to suggest that it was a transcript of an actual conversation between More and Giles. ${ }^{44}$ In this vein, instead of the two phases (in leisure in the Netherlands, hastily later in London) suggested by Hexter, Brian O'Brien argues that the composition of the text was more complex, involving four different phases, each adding new layers to the "ambiguities" and "equivocations" of the text, reinforcing its "status as a work of fiction". ${ }^{45}$ More

\footnotetext{
${ }^{43} \mathrm{Cf} . \mathrm{CW}(4, \mathrm{xxi})$.

${ }^{44}$ Others question the model for different reasons. For example, J. M. Parish argues that Seneca's De otio might be a common source for the two books, and proves that the debate about active versus contemplative life is an equally important organising theme in the two parts of the work. "Hexter's interpretative framework ought to be overturned or at least least significantly revised," as he concludes Parrish $(1997,498)$.

45 In line with Grace's opinion, Brian O'Brien talks about Hexter's concept as something out-of-date, numbering those who disregard the fictional aspect of the work as the "dissenting voices" (O'Brien 1992, 19).
} 
recently, Jean Francois Vallée argued that the insertion of the marginalia was yet another phase of the same process, and he claimed that the process itself could be regarded as "progressive dialogisation" (Vallée 2004, 45). That is where the underlying generic model of Utopia at last comes to surface.

There are many hints in criticism at the possible influence of the genre of Renaissance dialogue on More's work. Some of these come from studies of the work itself, but references to Utopia are also abounding in reviews of the genre itself, with either the English tradition or the more general Renaissance (above all, Italian) practice and theory under scrutiny. Strangely enough, and probably due to the manifold direction of interests, the results are rather scattered, and even when a work promises to bring together the study of early modern utopia and Renaissance dialogue, real exchange among the isolated opinions never seem to materialise. ${ }^{46}$ Therefore, in what follows, I briefly enumerate some relevant achievements from different fields, and explore the extent to which they can influence our reading of Utopia.

The introduction of the Yale edition contains many references to the genre of dialogue. Hexter's much-criticised imaginative vision about the conception of the work is obviously related to the art of conversation: as already noted, he introduces the idea that Utopia, or at least the Discourse on Utopia originates from an elevated discussion between More and Peter Giles about the best order of a commonwealth (CW 4, xxxxxxi). So, in Hexter's view, when in the letter to Giles, More writes that "I had only to repeat what in your company I heard Raphael relate," he is not far from facts, except for

\footnotetext{
${ }^{46}$ I am alluding here to the book entitled Printed Voices: The Renaissance Culture of Dialogue (ed. Heitsch and Vallée). Although the volume dedicates a whole section to the relationship between utopia and dialogue (The Utopia of Dialogue), the three subchapters, wealthy in important insights (many of them already referred to above, or to be referred later) as they are, concentrate almost exclusively on the English tradition, with almost no references whatsoever to the important Italian theories of dialogue.
} 


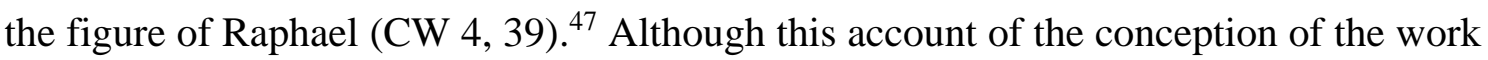
is by nature highly speculative, its core idea is definitely important: Utopia might very well originate from the ethos of humanistic conversation, and its written version, dialogue.

Edward Surtz, who refers to the genre in several places, in fact suggests precisely this in another part (Utopia as a Work of Literary Art) of the same introduction. It is important to remember his first specific claim about the structure of the work, as it will later gain profound importance: "More's theme almost cries aloud for the least complicated of all structural forms: a problem and its solution" (CW 4, cxxvi). Surtz, interestingly, finds that the second book of More's work cannot reach the first book's "outstanding level" of "structural unity, order, and movement" (CW 4, cxxix), and he even identifies inconsistencies and loose joints in the discourse. ${ }^{48}$ Then he goes on with the mentioned structural thread (problem-solution), and finds that in order to elaborate on the question, More employs the dialogue form, just like Plato in the Republic. Yet, Surtz also identifies a harsh difference between Plato's less agitated work and Utopia, claiming that the latter is not simply a dialogue, but it is a dramatic dialogue, which "employs techniques of the drama." 49 Whether it is appropriate or not

\footnotetext{
${ }^{47}$ Here it is probably worth to quote Hexter's reconstruction at some length: "All good things [i.e., More's time at leisure] end, however. Negotiation may have begun again in Bruges; but for whatever reason More left Antwerp. Since he still had nothing much to do, however, he began to set down the substance of his conversations with peter, elaborating on this or that matter that took his fancy, giving the whole a fictitious narrator, Raphael Hythlodaeus, and making himself and Giles the present but silent auditors to whom the narrator spoke (CW 4, xxx-xxxiii)."

${ }^{48}$ Lakowski is in agreement with Surtz, claiming that "the basic structure of Book I is actually more complex and multi-layered than that of Book II" (Lakowski 1993, 90-91 [28]), but he does not go as far as to talk about defects in Book II. Both opinions are at least indirectly contradictory with Hexter's observation about the first book's more ephemeral nature.

${ }^{49}$ Surtz argument for interpreting the work as a drama is brief: "Strictly speaking, of course, the dialogue in Utopia is narrative, i.e., "epic". Because of such features as intellectual conflict and emotional excitement, however, the Utopia can legitimately analyzed and criticized in dramatic terms." Cf. CW (4,
} 
to interpret Utopia as a drama is not my intention to decide, but because of the haste to move from dialogue to drama, his account is certainly unsatisfactory as to the role the dialogue form plays in the structure of the work. Still, besides the mention of dialogue there is at least another point in his account that we should remember for future reference. While he finds Book I a skilful dialogue, he claims that Book II is less successful in this respect, and although he initially calls it, in the proper dramatic terminology, a "monologue," later he suggests that it is more like a "one-sided dialogue" (CW 4, cxxxix). Not only the hesitation is important, but also the point that the more discursive Book II can be seen as the part of a dialogue, even if it is almost completely monopolised by Hythloday. ${ }^{50}$

Just a few years before the Yale edition, David Bevington has explored the question of the dialogue form of Utopia in details, as a key to the problem of the many contradictory interpretations of the work. For him, the dialogic nature suggests that the book should be regarded "the impartial presentation of two points of view, as a dialogue of the mind with itself" (Bevington 1961, 497). As for the genre, he establishes a link between dialogues and the more rhetorical English dramas of the time, some of which even originated from More's environment. He also links dialogue to court trials, in which More was obviously well-versed, and on this basis, stresses the form's

cxxxiv, n1). A similar opinion can be found in Reynold's book (Reynolds 1965, 117). On the other hand, David Bevington finds a drama-like interpretation useful as a means of distancing the views uttered in the dialogue from its author (Bevington 1961, 498).

${ }^{50}$ There are many other references to dialogues (especially, humanistic dialogues) in Surtz's wonderfully detailed account of the possible literary influences traceable in Utopia. The influence of the form itself is only acknowledged in the case of Plato, and there only in passing. Cf. CW (4, clvii). Surtz also reviews an infinite number of Renaissance political tracts, many of them dialogues in form, but he is more interested in parallels in content. Cf. CW (4, clxxi-clxxix). 
applicability to the representation of two sides of the same question. ${ }^{51}$ Then he launches a sustained attempt at reconciling the views expressed by Hythloday and persona More, and in his reading, it becomes clear that More's book is an impartial reflection on the possibilities criss-crossing in the historical More's head as he was considering entry into the service of Henry VIII. ${ }^{52}$ In a rather insightful way, he also recognises a structural similarity between Book I and the dialogue within Book I: in both scene of speaking, there are three interlocutors plus "stooge" or "dupe" characters (the lawyer in the Morton scene, Giles in Book I). He suggests that albeit their role may seem marginal, they in effect demonstrate a wrong way of reasoning, and raise trivial questions which would be indecorous from Hythloday's or persona More's mouth. ${ }^{53}$ Thus, Bevington's analysis reveals not only a self-reflexive thread about the proper mode of reasoning, but also an attention to one of the key theoretical concepts of Renaissance dialogues, decorum.

R. J. Schoeck's article begins in a similar tone, by arguing that neither treating the work as mere jeu d'esprit, nor reading it as a social blueprint is satisfactory, as the binary opposition between the two approaches may eventually "divide the man for all seasons into several men for different seasons" (Schoeck 1969, 19). Significantly, he

\footnotetext{
${ }^{51}$ More's supposed capability of looking at the questions at hand from various viewpoints has become a topos of scholarship. In fact, in her seminal essay, Elizabeth McCutcheon suggests that the frequent use of litotes reflects precisely this attitude: "litotes speak of a habit of mind, a tendency to see more than one side to a question." Cf. McCutcheon (1971, 119-120).

${ }^{52}$ This and similar interpretations are hampered by chronological inconsistencies. As O'Brien argues, Hexter made his reconstruction work by displacing More's entry into service as far as possible, in order to represent the More of 1516 as an "unengaged intellectual". However, O'Brien cites letters from 1517 where he is already mentioned as councillor, and claims that More received royal pension as early as February 1516. Cf. O'Brien (1992, 20-22).

${ }^{53}$ As he writes concerning the exchange between the scoffer and the friar in the Morton scene: "The primary object of the satire in this digression is not the court or the clergy, but the folly of unreasonable argument." Bevington (1961, 501).
} 
also mentions the rhetorical craft of the text, seeing it as a declamatio, where the questio is: "suppose there were a commonwealth based entirely on reason - could it work, and how could it work?" (Schoeck 1969, 23). This is a very important point, as rhetoric receives unfortunately little treatment in the Yale edition, though it may be at least as important an organising power in Utopia as the dramatic structure identified by Surtz. Nevertheless, Schoeck goes even further in his analysis, and argues that the work was seen by contemporary readers in the framework of the four causes of Aristotle. Out of these, one, the form, is dialogue, and then the proper question would be: "How does the dialogue work?" (Schoeck 1969, 24). What is possibly the greatest achievement among these early accounts of the Utopia's dialogic form, Schoeck then identifies different layers of dialogicity in the work: the obvious literary dialogue, the dialogue between humanists as represented by the letters before the text, and a more general dialogue between European Christendom and non-Christian, non-European cultures. Importantly, Schoeck extends the dialogic nature of the work to the paratextual elements surrounding it.

There are some other studies where, although the dialogue form is not in focus, it is peripherally mentioned, and these often contribute to a more refined view of the dialogicity of More's work. Peter Allen has probably written the first detailed analysis of the ancillary material attached to the book in 1963, where he argues that, within the original textual context, the discourse on Utopia becomes "an incident in a long discussion; it is not a separate book but the central subject of the conversation - a rather lengthy anecdote told to a group of humanists (Allen 1963, 100)."54 Blaim's formalist

\footnotetext{
${ }^{54}$ Yet, at the same time, he preserves the dual interpretation of the work, claiming that while the humanists evoked through the parerga are on one hand taking part in a literary game, they are also sharing in its ambiguity.
} 
study from 1982 partially focuses on dialogicity, but the term is here clearly used in the Bakthinian sense, closely related to the work's observed polyphony. Blaim's reading is quite interesting as an application of Bakthin's method, and in a rather commendable way, he argues for the inevitability of having many differing opinions of the work, as something resulting from its inherent polyphony. As for the dialogue form itself, the account has not much to do with the literary genre; it is more related to the act of communication. $^{55}$

Fortunately, the last few decades saw a rise of interest in the rhetorical composition of Utopia. ${ }^{56}$ At least some relevant results should be mentioned here, as they are carrying us in the desired direction. Damian Grace's 1989 article provides a meticulous dialectical analysis of the first book. Highlighting the role of dialectic in Utopia, and relating it to More's other works (for example, to self-reflexive statements in the famous Dorp-letter), the article is necessarily intertwined with the dialogue form itself. The passage most important for our current investigation is worth quoting at length:

In fact, the whole Dialogue of Counsel, so often seen as reflecting the debate in More's own mind about whether to enter royal service, raises the prior problem of communication. Quite apart from the criticisms and reforms proposed, the values of proper dialogue are represented in the personae of

\footnotetext{
55 "Neither the situation nor the personalities of the speakers have any direct influence upon the theme of their conversation. Thus the emphasis is on the dialogue itself as a chain of semantic reversals, alternations of different, often contradictory semantic contextures." (Blaim 1982, 16)

${ }^{56}$ The question of rhetoric has been discussed since the Yale edition by innumerable critics, to name but a few, Arthur McKinney, Elizabeth McCutcheon, and Damian Grace. Here I cannot elaborate on their results, only to the extent they are related to the dialogue genre.
} 
Morton, Giles, Morus, and even the uncompromising Hythlodaeus (Grace 1989, 283-4).

Once again, and in the context of an argumentation more elaborately developed than anything before, we see that a self-reflexive thread is identified in the work, that it can in fact be read as a dialogue on the nature of proper dialogue, drafted according to rules of an ideal dialectic. Another in-depth rhetorical analysis of the first book was published by George Logan in 1994, where he very convincingly shows that More's work, or at least its first book is structured according to precepts of deliberative rhetoric. ${ }^{57}$ At the same time, he claims that its dialogue form follows not so much the dialogues of Plato but those of Cicero (Logan 1994, 5) ${ }^{58}$ Thus, in the decades following the Yale edition, there is a movement from the very general dialogue concept appearing in the earlier works to a more refined one, where the form is placed into the proper context of its generic precedents and the wider "technical" framework of contemporary rhetoric and dialectic.

The enumerated opinions together suggest that Utopia has much to do with the genre so popular among humanists, yet the proper nature of this connection is left largely unexplored. Fortunately, there are at least a few works that explore the question from the other way around: instead of More's work, they set out to deal with the dialogue genre itself. Already the opening of Jon Snyder's monograph on $16^{\text {th }}$ century Italian theories of the dialogue is suggestive:

\footnotetext{
${ }^{57}$ According to him, the second book is more determined by the traditions of political theory than rhetoric, although the "praise of city" tradition is acknowledged as an important influence (Logan 1994, 105-106).

${ }^{58}$ The influence of Cicero on Utopia might be greater than the proportions in scholarship suggest. J. M. Parrish goes as far to claim Cicero as the inspiration (and a direct textual source) for the invention of the very word 'utopia' (Parrish 1997, 494).
} 
The idea for this book first occurred to me while preparing a study on Renaissance utopian fiction. The fact that so many major and minor utopian texts were written in the dialogue form aroused my curiosity (...). (Snyder 1989, vii)

Many of the problems he identifies shed new light on some of the questions haunting the study of More's masterpiece. According to his account, four prominent $16^{\text {th }}$ century Italian humanists, Sperone Speroni, Lodovico Castelvetro, Torquato Tasso, and Carlo Sigonio set out to write a proper ars poetica of the dialogue form. ${ }^{59}$ The principal reason for this undertaking was the painful lack of an ancient theory on dialogue, despite the obvious popularity of the form among the Greeks and the Romans as well, and the ubiquitous interest in it during the Renaissance. The undertaking was obviously triggered by a renewed attention towards Aristotle's Poetics: fashioned after his poetics of drama, the Italians tried to write the poetics for a genre that was live and working around them. This is the reason for juxtaposing these theoretical works from the second half of the $16^{\text {th }}$ century with More's somewhat earlier work: to a great extent, they are investigating the rules of a genre that was by that time (at least in Italy) after its heyday. Thus, the works based on which they are constructing the generic model for the dialogue are more or less contemporary with Utopia, and as Surtz's account of the traceable literary influences in Utopia suggests, many shared common topics and political views with our text.

The affinity of More's text and the theories about the genre are so close that Snyder even makes mention of Utopia in his account of Sigonio's model. As Figure 3-1

\footnotetext{
${ }^{59}$ In what follows, I am heavily indebted to (Snyder 1989), especially Chapter 2, where Sigonio's model is described. Although Snyder occasionally refers to Utopia (eg. p. 59), the described correspondence between Sigonio's model and More's work is only hinted at.
} 
shows, Sigonio's generic blueprint consists of two major parts: the praeparatio and the contentio. The primary function of the first part is to establish the circumstances of the conversation: it introduces the characters and the "scene of speaking" itself, and it is closest to everyday conversation (Snyder 1989, 55-56). This objective is clearly visible in the early parts of the first book of Utopia, when the actual circumstances (1), and the partners of the conversation (Giles and Hythloday, 2, 3) are appearing:

1. After we had met several times, certain points remained on which we could not come to agreement; so they adjourned the meeting and went to Brussels for some days to learn their prince's pleasure.

2. Of those who visited me while I was there, no one was more welcome to me than Peter Giles. He was a native of Antwerp, a man of high reputation, already appointed to a good position and worthy of the very best: I hardly know whether the young man is distinguished more in learning or in character.

3. One day after I had hear Mass at Notre Dame, the most beautiful and most popular church in Antwerp, I was about to return to my quarters when I happened to see him [Giles] talking with a stranger, a man of quite advanced years, with a sunburned face, a long beard, and a cloak hanging loosely from his shoulders; from his face and dress, I took him to be a ship's captain. (More 1995, 41-43)

Even a certain extent of restraint can be felt on More's part when he is recording his first impressions about Hythloday, replying to Giles, "He would have been very welcome on your behalf' (More 1995, 43, my italics). This is entirely consistent with Sigonio's concept of decorum (a central element in all the reviewed theories on dialogues), according to which the characters of a dialogue should be "the most eminent men of the republic, charged with its weightiest affairs and concerns" (Sigonio quoted by Snyder 1989, 59). Both More and Giles are fashioned in the text with the aim of fulfilling these criteria: the former is on a royal diplomatic assignment, while the latter 
is "of high reputation," and in "good position". The credentials of Hythloday seem to be far inferior, and Giles must first prove to More that the "fellow" is worthy of their attention, or more generally, that he is fit to partake in decorous dialogue: he "knows a good deal of Latin and is particularly learned in Greek," interested in philosophy, and widely travelled and experienced.

On the other hand, the wording of More's remark is quite significant here: after Giles' summary about Hythloday's virtues, he thanks him for "taking such pains that I might have a talk [colloquium] with one whose conversation [sermo] he hoped would give me pleasure (CW 4, 14-15)." Hythloday is a mere vehicle for a desirable sermo/colloquium, or if we extend this to the whole book: it is not (only) Hythloday's figure/story that matters, but (also) the act and way of retelling it. Many previously mentioned opinions seem to be reinforced by this passage, which is only the first instance of a series of remarks about the nature of sermo in the work.

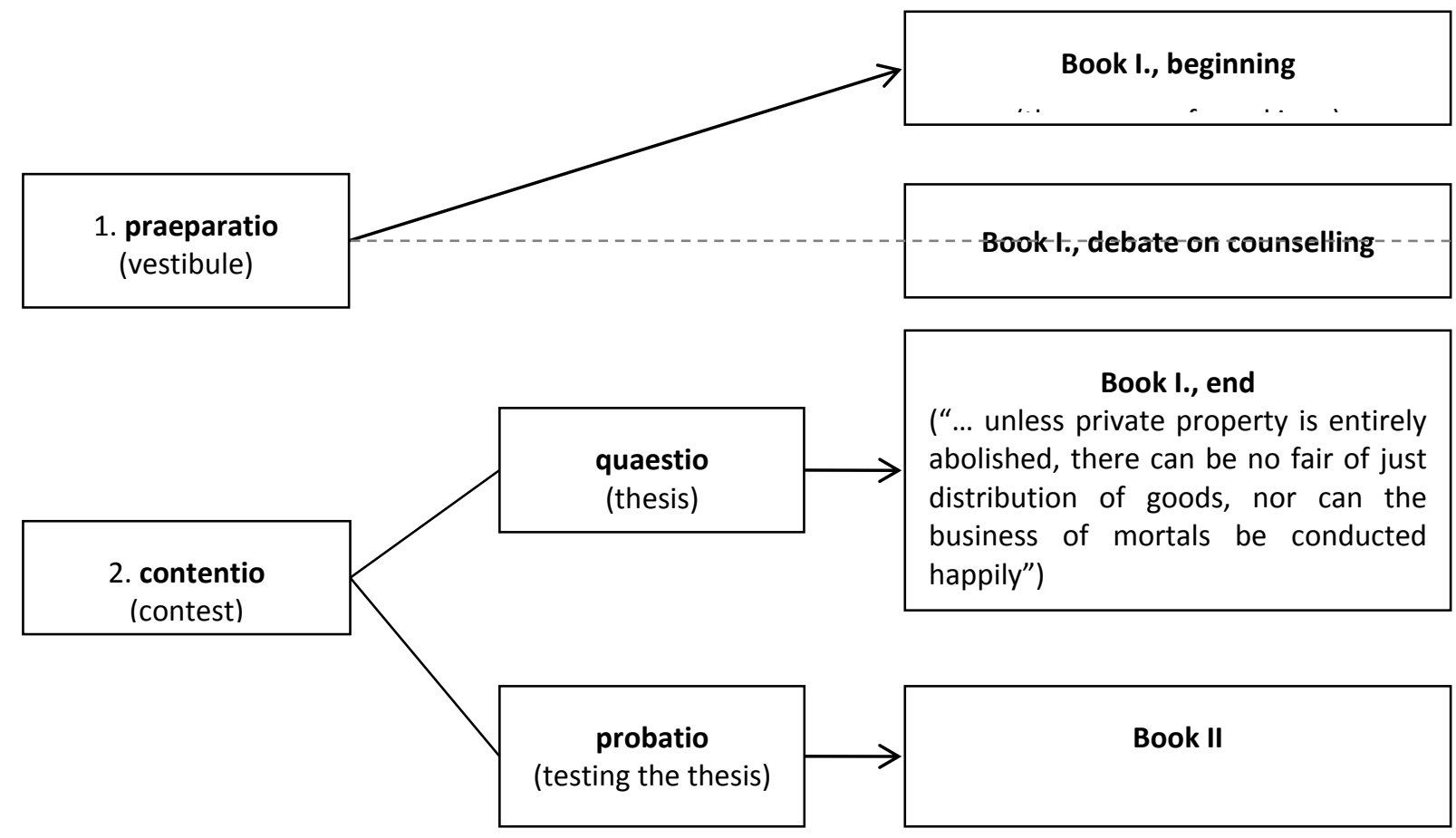

Figure 2-1. Sigonio's model and the structure of Utopia. Based on (Snyder 1989, 55). 
At first sight, the shift from praeparatio to contentio seems to take place at a very early point. In the first few pages, the text is talking about Raphael in the third person, with some distance (praeparatio?), then all of a sudden, we are in the middle of a debate on counsel, where the conversation is appropriated suddenly (and completely) by Raphael (contentio?). In the early passage which, in Hexter's concept, reveals the order of composition of the work, we once again encounter the word sermo:

Now I intend to relate merely what he told us of the manners and customs of the Utopians, first, however, giving the talk [eo sermone] which drew and led him on to mention that commonwealth (CW4, 54-55).

The term sermo seems to be of central importance here, as it is in fact applied as a generic label to the rest of Book I. ${ }^{60}$

Yet, what are we to do with that rest in light of the theories of dialogue mentioned? If the central quaestio, as it seems, indeed relates to the necessity of abolishing private property, why are we to deal with the question of counsel first? Part of the answer lies in the structure of the work. As the already mentioned Allen claims, the humanist conversation manifest in the letters surrounding the text deprives the second book of its separate position, and renders it "an incident in a long discussion" (Allen 1963, 100). Nonetheless, there must be some reason for the dual structure of the work, and this reason might be grounded in the ideal structure of dialogue as perceived by the humanists, which also explains the position of the debate on counsel.

In Sigonio's approach, there is a great division between the first and the second part of the proper dialogue, and More's work aptly follows the related rules. While in

\footnotetext{
${ }^{60}$ There are many other occurrences of the word (most - but not all - of them reviewed by Vallée), and its significance is reflected in the revisions as well - in one instance, the word oratio is replaced with "the more dialogical" sermo. See Vallée (2004, 60, n. 38).
} 
the praeparatio, the conversation may remind one of an ordinary discussion, the contentio is governed by different principles. It should always deal with a general question (in Plato's vein), and its testing (probatio) should be primarily based on dialectic. ${ }^{61}$ Thus, the point of change to contentio should be revised: instead of the point when the text changes from narrative to dialogic form, it is somewhere around the end of the first book. Why? Because the first debate is still related to actual political affairs. The debate on counsel is inescapably related to everyday practical politics, and if something, that should be avoided in a proper dialogue. It is avoided throughout the second book, which is only indirectly related to daily affairs, in line with persona More's arguments for a philosophy based on the indirect approach, as expressed in the first book:

On the contrary, by the indirect approach you must seek and strive to the best of your power to handle matters tactfully $(\mathrm{CW} 4,99-101){ }^{62}$

The concept of decorum once more comes into play, as this passage, the inconclusive conclusion to the debate on counsel is closely related to the question. For the more flexible philosophy advocated by More is one that "adapts itself to the play in hand, and performs its role neatly and appropriately [cum decoro] (CW 4, 98-99)."

Colloquium, sermo, decorum - the original Latin of More's work is infested with carefully placed rhetorical bombshells. Unfortunately, translations sometimes tend to conceal these, and even the prestigious Yale edition is no exception here. In a seminal article (mentioned briefly above), Jean-Francois Vallée calls attention to one

\footnotetext{
${ }^{61}$ See Snyder $(1989,61)$.

${ }^{62}$ On the significance of this passage, see for example Grace $(1989,282)$, Smith $(1991,130,138)$ and Logan (1994, 111-112). The latter is especially insightful, and relates More's concept to the decorum notion of Cicero and Quintilian.
} 
particularly problematic matter of the Yale translation (which is repeated in most other translations as well). According to Vallée, right before the quoted passage, More and Hythloday are arguing about the "nature of private and public dialogue" (Vallée 2004, 47). However, in the related passage, the Yale edition translates sermo as idea in More's criticism of Hythloday:

\begin{abstract}
Neither, to tell the truth, do I think that such ideas [huiusmodi sermo] should be thrust on people, or such advice give, as you are positive will never be listened to. What good could such novel ideas [sermo tam insolens] do (...)? In the private conversation [in familiari colloquio] of close friends, this academic philosophy is not without its charm, but in the council of kings, where great matters are debated with great authority, there is no room for these notions (CW 4, 98-99). ${ }^{63}$
\end{abstract}

The previous occurrences of these keywords add further force to Vallée's opinion that in Book I, the point is not (only) the debate on counsel but a less tangible debate on the nature of dialogue itself.

To sum up, Thomas More's Utopia is related to the genre of Renaissance dialogues on several levels and in different ways. First of all, it fulfils all the requirements and (with some modifications) closely follows the model described/prescribed by the experimenting Italian theorists of the dialogue. On the other hand, especially in its first part, it contains a not too ostensive thread of contemplation about its own nature, and thus addresses the same questions as the theories themselves, and it is similarly informed by questions of decorum. The prefatory material adds

\footnotetext{
${ }^{63}$ This passage is quoted in (Vallée 2004, 42-62). Repeating the passage featured in his article seemed inevitable for my present argument. What I have added to his results is the tracing of some further occurrences of the keywords. For discovering the problem he is to be credited.
} 
another layer to the dialogic nature of the work, and - together with the indecisive conclusion of the work - gets the reader involved, tries to inspire her/him to think the matter further. If the work is seen through this light, it appears as a peculiar hybrid, a dialogue where, through the multiple layers of dialogue, the proper method of writing dialogues is demonstrated or maybe rather inquired after. Yet, by the very nature of dialogue, the theoretical considerations are always intertwined with the question of using fiction. ${ }^{64}$ Since in this respect, the prefatory materials have much to tell, the next subchapter moves on to examine these.

\section{Fictional protocols in Utopia and its paratexts}

In the preceding parts, I have referred to the importance of the paratextual materials several times. Based on previous opinions, I have highlighted that they comprise an integral part of the work, deposing the book of its central position (Allen), that they might be viewed as one more layer of the work's dialogic nature (Shoeck), or in a similar vein, to be a step in the process of dialogisation allegedly observable in the work (Vallée). The best readers also registered the duality of the prefatory material: just like the work itself, the parerga is sometimes playful, sometimes serious. ${ }^{65}$ In what follows, I am going to take a close look at the material, and as before, my focus here is again directly related to the duality of interpretations. What I want to extract from these texts is the way they reconfigure the reader's attitude to the work. Or, to put it in another

\footnotetext{
${ }^{64}$ The go-between (fiction/nonfiction) of the dialogue form (a feature supposedly shared with utopias) is the central claim of Nina Chordas: "Dialogue, then, is a form in its own right, occupying a middle ground between ordinary conversation and oratory, as well as between fiction and nonfiction." (Chordas 2010, 21)

${ }^{65}$ The humorous vein is most prominent in Wooden's study, where he claims that a reconsideration of the material is inevitable, and arrives to the conclusion that the "contributors all join enthusiastically in the literary hoax which sought to establish Utopia as the authentic memoir of a returned traveller" (Wooden 1978, 159). Yet, this does not mean that he would deny the presence of the serious element in the prefatory letter - the two, according to him, are simultaneously present and equally important.
} 
way: I try to explore the "fictional protocols" put into operation before (as well as during and after) we encounter the first book of Utopia. ${ }^{66}$ Although the textual variance of the text will be taken into account to some extent (as recently recommended by Jürgen Meyer), the March 1518 edition will be the basis of my investigation, not only because it is the edition accepted as standard in scholarship, but also because it features the highest number of paratextual elements. Occasionally, I will briefly refer to other editions and consider the changes and their potential effects.

The March 1518 edition contains the following prefatory materials:

\begin{tabular}{|c|c|}
\hline $\begin{array}{l}\text { Position in } \\
\text { March } 1518\end{array}$ & Item \\
\hline 1. & Letter, Erasmus to Froben \\
\hline 2. & Letter, Budé to Lupset \\
\hline 3. & Poem, Anemolius' hexastichon \\
\hline 4. & Illustration, Map (1518 map) \\
\hline 5. & Illustration, Utopian alphabet \\
\hline 6. & $\begin{array}{l}\text { Poem, Utopian poem } \\
\text { - } \text { in Utopian } \\
\text { - } \text { in transcription } \\
\text { - in Latin translation }\end{array}$ \\
\hline 7. & Letter, Giles to Busleyden \\
\hline 8. & Letter, More to Giles I. \\
\hline & Book I and II \\
\hline 9. & Marginal notes \\
\hline
\end{tabular}

${ }^{66}$ I am borrowing this term from Lucian Ghita. See Ghita (2006). 


\begin{aligned} & \hline 10. Letter, Busleyden to More \\ & 11. Poem, Noviomagus' poem \\ & \hline 12. Poem, Grapheus' poem \\ & \hline 13. Colophon \\ & \hline 14. Printer's device \\ & \hline 15. Letter, Rhenanus to Pirckheimer, introducing the epigrams \\ & \hline\end{aligned}

Table 2. List of the ancillary materials surrounding the March 1518 Basel edition

Even a short glance at the list triggers two observations: first, the great variety in the types of complementary material (letters, poems, marginal notes, and illustrations); second, the catalogue of prominent names. As for the latter, there is no need to emphasise the weight a letter by an Erasmus or a Budé bore, but the others, though less known today, were also important figures of international humanism. ${ }^{67}$ Instead of their social position, however, I am more interested here in their contributions themselves.

Paratext nr. 1. is a letter by Erasmus. The affinity of More's text to Erasmus' Praise of Folly has already been highlighted, and we may remember some important literary considerations from his preface to that work. In light of this similarity, it is surprising (if not even perplexing) that this letter voices no opinion whatsoever about Utopia itself. Erasmus' lines are addressing More, and in a very delicate way criticise him for not devoting enough time to his studies and for failing a good, international humanist education:

What would this wonderful, rich nature not have accomplished, if his talent had been trained in Italy, if it were now totally devoted to the service of the muses, if

\footnotetext{
${ }^{67}$ There is neither space, nor need here to give a detailed account of these figures. Peter Allen has provided brief biographies about them in the first part of his article, where he stresses their importance in the context of European humanism. See Allen (1963, 92-99).
} 
it had ripened to its proper harvest, and, as it were, its own autumnal plenty?

$(\mathrm{CW} 4,3)$

If this letter has anything to do with Utopia, then it is a possible engagement in the debate on counsel. It was only published in the edition under scrutiny, and by that time, it might have become clear for Erasmus that More had finally taken the course of a councillor. ${ }^{68}$ At least the total silence about the work, as well as the enthusiastic but gently critical tone of the passage seems to allow for such an interpretation. It is nonetheless strange that someone who wrote so intriguingly about the mixing of the comic and the serious in literary works has nothing to say about the literary (or other) qualities of Utopia. If we consider the rest of the paratexts, we might develop the impression that in this case, Erasmus unfortunately missed the point, and took his task too seriously, failing to enter the game that the other contributors and contributions so eagerly did. With considerable exaggeration, he is similar to the "dolt" reported by Beatus Rhenanus, who at a gathering questioned More's authorial achievements, claiming that he simply reported what Hythloday had told him, obviously taking the fictitious framework seriously. ${ }^{69}$

On the other hand, Erasmus certainly had his well-grounded reason not to join the game. Perplexed by the same question, Pintér suggests that the cause of Erasmus' silence was that he "perceived some potential risk in More's outspoken criticism of contemporary Europe, and thought it best not to reveal his opinion on any specific aspect of Utopia" (Pintér 2010, 56). In my opinion, besides this pragmatic explanation,

\footnotetext{
${ }^{68}$ This is a constantly recurring question in scholarship, to which I have already referred above. Hanan Yoran resolves the supposed conflict between being a humanist and being a councillor by claiming that "there is a strict separation between [More's] works and the ideology of the establishment he served," a desirable but probably impossible separation (Yoran 2010, 6).

${ }^{69}$ The case is retold in the final paratext, Rhenanus' letter to Pirckheimer, which does not actually belong to Utopia, yet refers to it. See below.
} 
another reason, connected to the reform endeavours of Erasmus should also be taken into account. To understand this, one must consider his Adagia: a significantly expanded version of the proverb collection came out from Froben's press only months before the first edition of Utopia. The opening item in the several-thousand-strong collection runs as follows: "Friends Have All Things in Common". ${ }^{70}$ It is beyond doubt then that the work is close to Utopia not only in time but in theme as well. However, for Erasmus, this was obviously a matter of utmost seriousness, as his thoughts appended to the proverb attest. In his complimentary remarks, Erasmus demonstrates the proverb's occurrence in numerous classical authors, a review prompting him to the following exclamation:

[Plato] also says that a society will be happy and blessed where the words 'mine' and 'not mine' are never heard. But it is amazing how displeasing, yes, how hateful that community of Plato's is to Christians, although nothing ever said by a pagan philosopher is more in keeping with the mind of Christ (Erasmus, quoted in his own translation in Olin 1994, 59).

The vital role of communal property in Erasmian thinking is further demonstrated by the preface to the whole collection in its 1508 edition, which argues for the usefulness of such proverbs through the specimen in question. Here, Erasmus puts even more emphasis upon the similarity between pagan and Christian views, drawing a parallel between Plato's communitas and Christ's charitas in genuine theological terms:

Namely, it [charity] urges that, joined in friendship with Christ and bound to Him by the same force that unites Him with the Father, and imitating as far

\footnotetext{
${ }^{70}$ In this account I rely on the chapter on Erasmus and Utopia in (Olin 1994). I quote the commentary from the preface from his translation in the same place, pp. 58-60. Vallée also discusses the relationship between the Adagia and Utopia, see Vallée $(2004,44)$. He investigates the preface to the Praise of the Folly, but unfortunately, does not investigate the causes of the difference in tone when compared to Erasmus's contribution to Utopia.
} 
as we can that perfect communion by which $\mathrm{He}$ and the Father are one, we also become one with Him and, as Paul says, are made one spirit and one flesh in God, so that by right of friendship all that is His is shared with us and all that is ours is shared with Him (Erasmus, quoted in his own translation in Olin 1994, 63).

The second book of Utopia contains a short passage where the same parallel is drawn, but not at all with the same depth, only in passing. ${ }^{71}$ Although it is tempting to link the difference in this matter to Erasmus's silence about Utopia, it might easily lead to over-interpretation. Still, the difference makes one think. In his famous letter about More, written to Ulrich von Hutten, Erasmus includes a short passage about Utopia:

He published his Utopia for the purpose of showing, what are the things that occasion mischief in commonwealths; having the English constitution especially in view, which he so thoroughly knows and understands. He had written the second book at his leisure, and afterwards, when he found it was required, added the first off-hand. Hence there is some inequality in the style. ${ }^{72}$

Short as this remark is, it is obvious that Erasmus prefers the second book to the first one. Probably he was familiar with the work from its birth, when it was only a discourse on Utopia (second book) and saw what it was becoming with the addition of a first book and the ever-expanding set of ancillary materials - and did not like what he saw. Maybe he disapproved of the way the first book and the letters engage in the game about Utopia and Hythloday, relativising and trifling the topic that was of such profound importance to him. Maybe he thought that this time the right balance between

\footnotetext{
71 This is in the chapter on Utopian's religion, where Hythloday attributes their ready reception of Christianity to Christ's teaching about the "common way of life." Cf. CW $(4,219)$

72 Erasmus, letter to Ulrich von Hutten, dated 23 July 1519 . Available: http://www.thomasmorestudies.org/docs/Erasmus\%20to\%20Ulrich\%20von\%20Hutten.pdf, date of access: 22 July 2013.
} 
the serious and the comic was missed, and his refusal to play the Utopian game indeed implied criticism. Based on the Adagia, this would be a logical conclusion.

Paratext nr. 2., the letter by Budé is much more interesting for the present discussion. ${ }^{73}$ Already at its outset, he calls Utopia a "very pleasant" and "profitable" reading, reiterating the Horatian literary commonplace to be employed later by More himself in paratext nr. 8. Then he admits that he had been mostly impressed by the customs of the Utopians, and talks about the injustice of human laws as opposed to natural laws. He even touches upon the question of common property, and although up to this point, he pursues a "proto-Marxist" kind of reading, some interwoven phrases of delicate scepticism carefully counterbalance this strain:
Now, the island of Utopia, which I hear is called also Udepotia, is said, by a singularly wonderful stroke of fortune (if we are to believe the story), to have adopted the customs and the true wisdom of Christianity for public and private life and to have kept this wisdom uncorrupted even to this day. (CW 4,11 , my italics)

On one hand, Budé partakes in the Utopian play with words, and hints at another reading of the island's name, which displaces the island not in terms of its location, but in term of time as well. Then, in a somewhat ironic tone, he is wondering whether it is possible at all to talk about an uncorrupted Christian way of life. Probably that would be just enough to get a sense of his scepticism, but Budé does not want anyone to miss the point: in the highlighted aside, he explicitly questions the authenticity of the story. The true significance of this remark lies, however, not in the obvious warning it presents to the reader. More importantly, Budé, who finds the customs of the Utopians wonderful, and discusses the values of true Christianity in his prefatory letter, demonstrates an ideal

\footnotetext{
${ }^{73}$ Allen and Wooden both find this letter crucial in their respective readings of the parerga.
} 
reading of the work, one that engages in its discussion of the most serious real-world matters, seeing no tension between these and the work's basically imaginary nature. Maybe the story is not true. Nonetheless, neither is it important, as - besides numerous sceptical phrases - his conclusion suggests: "I personally, however, have made investigation and discerned for certain that Utopia lies outside the limits of the known world $(\mathrm{CW} 4,13) . "$ Budé's letter is a good example of how some of the prefatory materials take part in the discussion of the work itself, while at the same time, instead of trying to disguise it, they straightforwardly call attention to its fictitious nature. ${ }^{74}$

Paratext nr. 3, Anemolius' hexastichon is the first among the poetic kind of paratextual materials, and it contributes to the discussion about the work with important literary and theoretical insights. Its typography suggests a unique place within the structure of the parerga: the long title and the six lines are placed in the middle of a recto page, and they are surrounded by vast empty spaces. Unimportant as it seems, it must be noted that this is something that the reader sees nowhere else in the publication. For example, paratext nr. 11 and 12, which are two poems, follow a letter by Busleyden without even a page break, with only a line between the text of the letter and the poems. Besides its content, this is another hint that the poem deserves closer inspection than it usually elicits.

Like Budé's letter, the short poem also plays with the word 'utopia', and it is here that a third rendering of it occurs: eu-topia, that is good-place. So, Goodplace (Eutopia) is Nowhere (Utopia), but it is also Neverland (Udepotia). By the third

\footnotetext{
${ }^{74}$ In Allen's reading, the main point of Budé's letter is that it calls attention to the fact that the work shows Christian principles to European readers. Although he registers that "the appended material shares in the deliberate ambiguity of Utopia", here, and elsewhere too he overemphasises the serious (as opposed to the comic) element. Cf. Allen (1963, 101, on Budé's letter: 104-5).
} 
paratext, besides Budé's explicit questioning of Utopia's actual existence, the successive alterations of the geographical name and their not-so-hidden meanings themselves call into doubt both the spatial and the temporal existence of the island more implicitly, on the level of words, carrying on More's initial pun. More importantly, the short poem claims that Utopia surpasses Plato's Republic because it shows good polity not only on the level of words, but "exhibited in men and resources and laws of surpassing excellence". The poem reinforces the ambiguous nature of the work: while it purports to be written by the inevitably fictitious "nephew of Hythlodaeus" indicated as its author, it compares Utopia to Plato's Republic, establishing a direct link with the probably most important classical literary precedent of the work, thereby stepping out of its fiction-supporting role. Some of the very terms used in the poem obviously refer to the act of imitation: Utopia is a rival [aemulo] of Plato. From this act of emulation or contest, Utopia emerges as the winner: whereas the ancient text merely delineates [deliniauit] the ideal state, More's version also exhibits [praestiti] it, thereby surpassing its pattern. This passage is obviously associated, besides ancient and Renaissance theories of imitation, with concurrent ideas about the relationship between philosophy and literature as well. Creating a hopefully fruitful circular reference, one of the closest near-contemporary parallel comes from Sir Philip Sidney's Defense of Poesie, where it is precisely Utopia that Sidney uses as an example for his claim that poetry surpasses philosophy, in an argument strikingly similar to the one in the hexastichon:

But even in the most excellent determination of goodness, what philosopher's counsel can so readily direct (...) a whole commonwealth as the way of Sir Thomas More's Utopia? (...) For the question is, whether the feigned image of poetry or the regular instruction of philosophy hath the more force in teaching. (Alexander 2004, 21) 
The peculiar use of Utopia as an example here has been studied by Scott D. Evans, and he concluded that More's implied theory of fiction is not that far from Sidney's, "advocating what is essentially true through what is literally false" (Evans 1996, 28). The short poem effectively supplements Evans's insights, and in its extremely concise form summarises one of the central points of Sidney's less concise work. The similarity can also be observed in the choice of words, as Sidney uses overlapping terminology when he is talking about the types of imitation:

Poesy, therefore, is an art of imitation, for so Aristotle termeth it in his word mimēsis, that is to say, a representing, counterfeiting, or figuring forth - to speak metaphorically, a speaking picture - with this end: to teach and delight. (Alexander 2004, 10)

Even though Sidney, as we saw, makes specific reference to More's Utopia, the affinity in terminology by no way intends to suggest a borrowing by Sidney from his predecessor. Of course, this is shared terminology, originating from Aristotle, Horace, and other ancient and Renaissance sources. ${ }^{75}$ What is important, though, is that such a close terminological and conceptual overlap can be registered between the first "proper" utopia and the first important English apology of literature. And if so, should not the question of the literary facet of Utopia be revisited? Just like in Plato's Republic, there is not much to learn about poets or literature in Utopia. However, a close reading of the short poem reveals an important literary agenda in operation in the underlying structure of the work, and one that is a harbinger of Sidney's later theoretical considerations. This relationship has a wider implication extending to the whole genre of early modern

\footnotetext{
75 The following names are connected to the quoted passage in the edition of The Defence of Poesy by Gavin Alexander: Scaliger, Trissino, Castelvetro, Mazzoni, Tasso, among the ancients: Plutarch (who attributes the concept of "poetry as a speaking picture" to Simonides) and of course, Aristotle, and Horace. See Alexander $(2004,325, \mathrm{n} 35)$
} 
utopias, and at least partly explains their popularity: early modern utopias, by their very nature, were at the intersection of key questions of contemporary poetics. And, as this poem proves, they were often completely aware of this peculiar position (CW 4, 1965, 20-21). Should one read Utopia without considering these few lines, s/he would lose a profound self-reflexive, literary-theoretical strain of the work.

Paratext nr. 4 through 6 can be regarded as one group among the rest, where the theoretical desideratum of "praestiti" is put into practice. According to the program announced in the hexastichon, mere (philosophical) speculation about the ideal commonwealth is supplanted here with visual representation. The island itself is displayed through an engraved map (nr. 4.), whereas its language is not described (as later in the main text) but actually represented via spectacular samples: besides a table of the Utopian alphabet consisting of geometrically shaped letters (nr. 5.), its practical application in a poem (nr. 6.) is also exhibited. The content of the poem itself is quite close to the hexastichon, its central idea summed up in its middle part:

I alone of all nations, without philosophy, have portrayed [expressi] for mortals the philosophical city. (More 1995, 23) ${ }^{76}(\mathrm{CW} 4,19)$

The paradoxical structure again draws a contrast between Plato's Republic (the phrase "philosophical city" obviously refers to it) and Utopia, and the advantage over the predecessor is once more the very act of representation. That act is nowhere as tangible as here: the praise of Utopia is even set in Utopian typeface, so the advantage over Plato is not simply stated (literis deliniauit), but it is at the same time demonstrated (praestiti,

\footnotetext{
${ }^{76}$ In contrast to my regular practice, here I quote the 1995 Cambridge translation of the text. The Yaleversion seems to be to far-fetched in this place, and instead of "philosophy" writes "abstract philosophy", although the Latin original contains no word that could be/should be rendered as "abstract". Neither does the word appear in Robinson's rhymed translation.
} 
expressi), too. In their combined effect, the map, the alphabet and the poem invite the reader to a certain way of reading and thinking: it is her/his imagination that should be stirred by the typographical artefacts which are not from one generic ideal commonwealth but from the very specific island of Utopia.

It must be noted, though, that the duality overarching the whole edifice of the prefatory elements is present in this small group too. The map featured in the book does not really conform to Hythloday's description at the beginning of Book II, and the way the map is redrawn for the second and subsequent editions is also remarkable. ${ }^{77}$ Wooden and Wall notice that this enhanced version of the map by Hans Holbein introduces new perspectives to the originally simpler, two-dimensional engraving: the banners and the three figures are new additions as compared to the plainer 1516 version, and they employ perspectives that are different from the viewpoint required from the viewer to view the map itself. This game of different angles is, in their opinion, a call to supervise one's received notion about perception in general, and serves the same purpose as the other prefatory materials: to make us aware that whatever perspective we apply (while seeing or while reading), it is only one out of the many possible perspectives (Wooden and WALL Jr 1985, 242-245). They also note that the final two lines of the poem ("Freely I impart my benefits; not unwillingly I accept whatever is better" (More 1995, 23)) emphasise Utopia's past and future openness for change, Utopia's "willingness to engage in dialectical discourse" ((Wooden and WALL Jr 1985, 232)).

\footnotetext{
${ }^{77}$ In connection with this discrepancy, Wooden claims that the map, and especially its later version is "manifestly and grossly incorrect, a direct contradiction of the geographical description furnished by Hythloday." Cf. Wooden (1978, 156-7). He also finds that the geographical description itself is consciously distorted by heavily inflated figures.
} 
Paratext nr. 6. is a letter from Giles to Busleyden, and on one hand, it contains literary considerations expressed in visual terminology, while on the other hand, it takes part in the game about Utopia as well. Many ideas of Giles are already familiar from the items previously discussed. First of all, like in the poems, it is also self-evident here that More's work is "superior to Plato's republic" (CW 4, 21). Plato's work is mentioned here consecutively for the third time in the paratexts, making a strong case for the model followed by More in his work. Secondly, while praising More's achievement, Giles effectively paraphrases the previous two poems with a repetition of the key technical terms:
(...) a man of great eloquence has represented [sic expressam], painted [sic depictam] and set it before our eyes [sic oculis subiectam] in such a way that, as often as I read it, I think I see far more than when, being as much a part of the conversation as More himself, I heard Raphael Hythlodaeus' own words sounding in my ears. (CW 4, 21, my italics)

Giles' sentence is abounding in expressions that relate it to the theoretical notions in the previous paratexts, but it is no simple repetition of what had already been uttered in the poems. Instead, Giles offers a synthesis from the reader's point of view. In the two poems, it was in effect the "book" itself that was talking about its own representative (as opposed to philosophical/speculative) nature, but here the perspective is that of a reader, and a rather self-reflexive reader he is. For Giles, the ideal reader, reading means seeing: the boundary between verbal and visual arts disappear, Utopia works for him as a "speaking picture". This is, of course, a remarkable judgment indeed: the representation of the actual conversation is superior even to the original act represented. To put it in other words: seeing is believing, and reading fiction is the best way of seeing. The next paratext is a letter by Giles, so in effect, an indirect dialogue emerges between two of the characters who also have a fictional counterpart. Thus, 
through a gradual process (from Erasmus' complete silence about the book to two of its persona engaging in a dialogue about it) readers get more and more involved in the book to come, but their perspective as readers is first fine-tuned by the self-reflexive insights of the prefatory material. This is nowhere as visible as in the next, and the probably most widely known item from the parerga, the letter from More to Giles.

Paratext nr. 7., then, is a letter from More to Giles, being the first exchange of letters that is conducted between two characters who are actually present in the body of the work. This lends particular importance to this paratext, so it is no wonder that for example in most Hungarian translations, even if the majority of the prefatory material is lacking, this letter is included in the editions. It shows that readers (and editors) make a natural distinction between this and the other ancillary materials where the sender and/or the addressee is someone who does not appear in the main text. The special status is also marked by the presence of annotations: while marginalias are found throughout book I and II, they are not present in the other paratextual elements. There is indeed an important shift in perspective here: previously, Utopia, the book was referred to from an external viewpoint, while here, the role of the author and one of the characters is simultaneously assumed. Unfortunately, when More comes to word, some of the duality observed in the rest of the prefatory material vanishes, since it is already persona More who is talking here. In its fictional status, he is no different from the More character of Book I and II, and if we had a sense that the other letter-writers preserve at least a part of their real-world identity (particularly Erasmus, but to some extent even Giles), this is not the case with More. ${ }^{78}$ In fact, More's letter serves as a

\footnotetext{
78 That this distinction poses challenge to readers is most palpable in connection with More. In his article, Bevington makes a sharp distinction between the "historical" and the "persona" More, the latter being the character in the book. Decades later, Lakowski feels compelled to refine that distinction further. He
} 
reminder for the reader that even though real names frequently occur in the prefaces, they are part of a larger, explicitly literary framework, which transforms most of them into pure fiction, even if they purport to be nonfictional. As we will see later, such mingling of fiction and nonfiction (for example, a fictional narrator writing a dedication to a real person) is rather frequent in early modern utopias.

Because of this special status, this letter attracted exceptional attention in studies on Utopia: it might be the only paratextual element receiving a monograph-length treatment. Elizabeth McCutcheon's book is probably the most elaborate discussion not only of this letter in particular, but of the poetics of Utopia in general, as well. More recently, Lucian Ghita's insightful study also stressed the importance of this letter to the understanding of the use of fiction in the work. For both authors, the most important part of the letter is the middle section, which deals with the question of fiction in an almost completely explicit way, culminating in More's utterance:

For, as I've taken particular pains to avoid having anything false in the book, so, if anything is in doubt, I'd rather say something untrue than tell a lie. In short, I'd rather be honest than clever. (More 1995, 35) (99 $^{2}$

Nowhere else in the book does the reader encounter such an open invitation to consider the question of fiction in connection with the book. In my opinion, the above sentence, with its careful rhetoric, can be read as a general statement about the work: even if it is fiction, that is, "untrue," it does not follow that it is "false," that it is a "lie."

distinguishes between a historical character (the »real« More), a "semi-fictional" More ("Author More") who speaks in the letters to Giles, the "persona More", who is the speaker in the dialogue of Book I, and a "Narrator More", who speaks at the beginning of the first book and at the end of the second book. Although he is certainly right in that criticism has often failed to properly distinguish between the real More and the More in the book, his distinction might be too refined. It is hard to see why the character at the beginning and the end of the book should be different from the one engaged in the dialogue. See Lakowski (1993, esp. chapter 3.3).

${ }^{79}$ Here again, the 1995 translation is more accurate than the unnecessarily verbose Yale. 
We are back in the realm of early modern poetics, and especially Sidney's Defense, where the apologist is refuting the accusation that poetry is "the mother of lies":

Now, for the poet, he nothing affirms, and therefore never lieth, for, as I take it, to lie is to affirm that to be true which is false. (...) And therefore, though he recount things not true, yet because he telleth them not for true, he lieth not (...) (Alexander 2004, 34)

Just like in the case for the superiority of representative literature over abstract philosophy, More and Sidney are in complete agreement here. And if we recall that in Sidney's concept, literature is the realm of "what should be," then it is obvious that More wants to make the reader aware of the fictive nature of his work. Notwithstanding the detailed, lively picture painted in the second book, Utopia is not an actual country it is a fictitious country, that is, a picture showing how a country should be. More's speculation about the working of fiction fits well into the self-reflexive literarytheoretical strain of the parerga.

More's letter to Giles is the last one before the "actual" work, so the rest of the paratextual material comprises another group. There is one paratextual element (the marginalia, paratext nr. 9 in the above table) which establishes a link between the items before and after the text. This way the text is nowhere present "as is", but a certain extent of mediation is performed before, after, and inside the text, too. The marginalia works in a very peculiar way: although they do not usually go further than summarising the actual point of the main text, at certain points they obviously try to push the reader into specific directions of interpretation, like in the following instances:

An Horatian Allusion (...) (83/C)

In this feature, too, London agrees with Amaurotum. (119)

These features smack of Plato's community. (121)

The usefulness of Gardens Proclaimed also by Virgil. (121) 
Evidently This Passage Is Satiric. (159) ${ }^{80}$

Besides giving hints at interpretation and performing source criticism, the body of comments serves another purpose, too. Because of their constant presence, they offer a "fellow" model reader for the actual reader. Thus the reader is invited to follow this model, and engage in a critical dialogue with the text, in the same manner as the characters in the book engage in a critical dialogue with Raphael. ${ }^{81}$ It is also clear that this parallel reader makes the actual reader suspicious of his own readerly perspective, as it is suggested by Wooden and Wall. ${ }^{82}$

The closing of the second book is followed in the edition under scrutiny by paratext nr. 10, Busleyden's letter to More. This letter is primarily interested in the social aspect of More's work, and does not deal with the question of fiction, neither does Busleyden show any sign of the playfulness witnessed in some of the other letters. For him, it is only the cause of the commonwealth that matters, and when More is praised, he is not praised for his performance as a writer, but for devoting his "pains, labor, and energy" not only to the advantage of individuals but also to that of the general public.

The significance of the final two poems (paratext nr. 11 and 12) lies in that they are both addressing the reader. Whereas the previous exchange of letters happened within a closed circle of elite humanists, here the reader is explicitly addressed.

\footnotetext{
${ }^{80}$ Page numbers refer to the Yale edition, except for the first, which seemed more faithful to the original in the Cambridge edition.

${ }^{81}$ That is why it is appropriate to treat the marginalia as another layer of dialogicity, like Vallée does (see in the previous subchapter).

${ }^{82}$ Wooden and Wall draw a comparison between Renaissance anamorphic paintings and Utopia, claiming that the book consists of a "series of frames," which make the reader "experience a series of perspectives of the central subject." In their thought-provoking concept, the marginal comments "serve as angles of discernment for the reader, forcing him to decide whether or not he agrees with each judgment". Cf. Wooden and WALL Jr (1985, 244, 252)
} 
Geldenhauer recommends the book (of course) because it is both profitable and delightful, but it is interesting what the profit of the book is according to him: "To sharpen at once both your thoughts and your speech" (More 1995, 257). Tiny and wellhidden as this remark is, it fully supports the supposition that Utopia is - among many other things - about the proper way of using the language. It also means that the selfreflexive literary thread is preserved until the very ending of the book, as the main advantage is not that the reader can imitate the wonderful virtues of the Utopians (not the content) but that he can improve in "thought and speech," so in fact that he becomes a better reader and writer. De Schrijver's poem, on the other hand, offers no such selfreflexivity, and serves more or less like an advertisement for the book, briefly cataloguing its contents: monsters from the new world, new ways of life, human virtue, and "the void beneath all things" are the most compelling properties of Utopia in the poem's reading.

Finally, we should briefly touch upon two paratexts which are, for different reasons, not so closely related to the present investigation. One is More's second letter to Giles, which was only published in Paris 1517 , and the other is Rhenanus' letter, which pertains already to the epigrams bound together with Utopia. In the 1517 edition, More's second letter followed the second book, and if one undertakes to investigate the working of fiction in Utopia, this letter cannot be neglected. The letter addresses Giles again, thus forming a frame around book one and two, and it addresses the questions under discussion in an embarrassingly direct way. It is a reply to a "very sharp fellow," who claims that if the work is fact, then it is absurd, while if it is fiction, there was some problem with More's good judgment while writing it. Both the question and the answer, as well as the terminology used here is very interesting. Initially, More is very happy to identify the model reader of his work in the judge of his work, who reads "slowly and 
carefully in order to consider all points thoughtfully" (More 1995, 267). So far so good, but when More comes to defence, he indeed seems to lose his "usual good judgment," and reaches the level of pedantry. Both accusations are addressed by him: if there are absurd concepts in his work, well, there are absurd concepts in the works of "all the philosophers who have offered a pattern of a society." With this logic of refutation, More effectively admits of being the author of the whole work (not simply the amanuensis of Hythloday, as the original framework suggests). However, when he discusses the fictitious nature of the book, he gives away too much:

But I would certainly have softened the fiction a little, so that, while imposing on vulgar ignorance, I gave hints to the more learned which would enable them to see what I was about. (More 1995, 268)

A list follows then, where the speaking names from Utopia (Utopia, Anyder, Amaurot, Ademus) are called "barbarous and meaningless names," which More preserved only because of the "veracity of the historian" (Ibid.). Since he even hides the translations of his geographical names into the passage, the whole business becomes exhaustingly over-explained. As a statement in itself, More's letter is important, because nowhere else it is so clearly admitted that the work is, by the intention of its author, balancing on the invisible borderline of fact and fiction. Yet, as a letter following the work, and as a letter from a series of letters included in the book, it is a game-spoiler. One can only agree with Allen, who thinks that the letter was omitted from later editions because "perhaps it was remembered that good jokes lose their savor the more they are explained (Allen 1963, 101)". More's second letter to Giles, it can be argued, is a final, very harsh warning for the reader that he/she should not take the book in earnest. 
Pirckheimer's letter (paratext nr. 15) is outside the boundaries of the work, but present in both Basel editions only pages after Utopia, as a preface to the epigrams of More and Erasmus. At one point, the preface refers back to the work, and does it in a less delicate way. First, he praises the work, and compares it to Plato, Aristotle and Justinian, although "[i]ts lessons are less philosophical, perhaps, than theirs but more Christian." A serious reader we have here, who finds "principles" the most important element of the work. And when it comes to its fictitious nature, he simply ridicules the "jolt," who at a conversation tries to fade the importance of More by claiming that "all More said was taken from the mouth of Hythlodaeus and merely written down by More." And then, with a sudden and significant change to Greek, he concludes that More's wit should be praised for being able to deceive upon serious men. For Pirckheimer, it is no question at all, whether Hythloday or Utopia actually exists, and by calling this episode a "good story," it is also clear that in any good readers, these are similarly beyond question (all quotes are from CW IV, 253).

To sum up, when the paratextual elements are read with a focus on self-reflexive literary remarks in them, they yield a wealth of information, which calibrate the reader's expected attitude to the work. Throughout the ancillary materials, there runs a thread of inquiry as to the function of literature and the working of fiction. The close comparison of Sindey's later text revealed that More's text is much more than a passing reference in Sidney's oration. In fact, in a very compressed and indirect way, Utopia offers a defence of fiction and literature, or at least, brings to light questions which became really important for vernacular English literature only more than half a century later. The simultaneous reading of these paratextual elements also showed a progress from what Genette would call "original" prefaces to different sorts of fictive prefaces. While 
the opening letter, Erasmus' contribution, is a conventional, nonfictional preface, the rest of the items are more and more interfused with fictitious elements. But even when they engage into the game, they never fail to offer warning for the careful reader, even in the letter (More's letter to Giles) that serves as a transition from the semi-fictional parerga to the fully fictional first book. It is also remarkable that the number of paratextual elements is so high, and in my opinion, in this we must see not simply the work's anxiety with its own fictitious nature, but also its confused attitude to its own, still relatively novel vehicle, the printed book, as claimed by Lucian Ghita. All in all, it is obvious that reading Utopia without the paratext is an impertinent readerly attitude, leading to a necessarily distorted and simplified reading of the work. Naturally, this thread must have had a great impact upon the later followers, too.

\subsection{The life of the paratexts in early editions and translations}

After this close look at the specific elements of the paratextual material, it is worth to turn our attention back to the paratexts as a group. In the previous subchapter, I argued that at its birth Utopia was emplaced into a carefully constructed system of paratextual frames, which was again and again readjusted with each new early edition. Here I would like to take a very brief look at the ways later Latin editions and the German and the English translations handle the question. This is a fascinating phenomenon in itself, but it also provides important insights into how the presence or absence of the paratextual elements is capable of shifting the balance of the work. As we will soon see, stripped from all its frames, the text is prone to be understood as a serious work on policy and governance, while presented in a different serving, it naturally finds its place in an interesting anthology of humorous wisdom in the seventeenth century. 


\section{The Latin editions}

Thanks to the Disclocations project already mentioned at the outset of this chapter, we now have a very accurate overview about the Latin editions of More's work. ${ }^{83}$ Up to 1650 , the work was published 20 times, but interestingly, just like the first four editions already discussed, the others also tend to appear in specific conglomerations connected usually by those involved in the production of the given editions. ${ }^{84}$ As for the number of paratexts, they show a great variation between 8 and 16, with the lowest number of them found in the first edition outside the original context, the 1519 Florence edition. This variance suggests some editorial freedom in connection with the paratextual material, but it must also be noted that what are most frequently missing from these later editions are those non-textual pieces which were technically more challenging to reproduce (like the map and the Utopian alphabet), so the selection was not necessarily governed by high-soaring editorial principles.

Except for "variant titles, permissions, signs of censorship and the like," there is, interestingly, only one example for the introduction of a completely new paratextual element (Cave 2008, 28). The 1620 Milan edition contains a new preface by the editor Giovan Battista Bidelli, which is addressed to Giulio Arese, the newly elected president of the Senate of Milan. The concise text compares the dedicatee to More, whose work is seen as "small in size but great in wisdom," and which might be useful for the new senate because of "the truth he [More] expressed in a playful spirit (Cave 2008, 275)."

\footnotetext{
${ }^{83}$ It is therefore important to notice here that my account is based on (Cave 2008, 14-31), the chapter entitled 'A Protean text: Utopia in Latin, 1516-1631' by Vibeke Roggen.

${ }^{84}$ According to Roggen, out of the 15 editions published after More's death, only three could be regarded as independent publications, while all the others are connected via someone involved in the publication, forming a peculiar network revolving around Löwen, Basel, Hanau and Amsterdam. See Cave (2008, esp. 30-1).
} 
That More mixes seriousness with humour in the book is also mentioned later in the preface. The printer is obviously aware of the humorous nature of the work, but makes no attempt whatsoever at entering the Utopian game of the original prefaces. His preface remains strictly within the conventional realm of "original" prefaces, expressing nothing more than the writer's strive for winning the favour of the new president.

All in all, the Latin editions seem to be heavily determined by the first cluster of editions. At least half of the paratexts is always present (if rearranged), and there is only one exception to the rule that no new material is added to the original package. However, there is one odd member within this group, the 1619 Hanau edition, where even the term "edition" seems to be misleading, as Utopia appears within a gigantic anthology compiled by Caspar Dornau (1577-1632). The anthology consists of two volumes, and the first one ends with Utopia. The title of the collection is Amphiteatrum sapientiae socraticae joco-seriae," and contains a wide variety of texts from ancient to contemporary authors, classified under a strangely structured system with headings ranging from plant and animal names through abstract notions ('Nihil,' 'Aliquid') to "Utopia". The work shows considerable generic diversity, containing, among others, declamations, academic disputations, scholarly works, epigrams, elegiac poems, figure poems - and Utopia. ${ }^{85}$ Without going into any further details regarding this unique and rather disparate - collection, it must be noted that despite its anthology format, when it comes to More's text, the volume contains more than half of the original prefaces, and what is left out are preciselyy those illustrative elements which might have

\footnotetext{
${ }^{85}$ See Seidel $(1994,340)$.
} 
not fit into the general concept of the anthology. ${ }^{86}$ Despite relocating the work in a completely new context, the editor leaves it more or less untouched, just like the other editors of the Latin editions. The original text and its original paratexts form an organic unit in the $16^{\text {th }}-17^{\text {th }}$ century. From this vantage point, it is worthwhile to take a look at the German and the English translations, which have a different story to tell.

\section{The German Translations}

There are several reasons to single out the German renderings of Utopia when discussing the vernacular translations of the text. First, the earliest translation of Utopia is the German, published in Basel as early as 1524 , being the only translation published still in More's lifetime. On the other hand, already this first rendering demonstrates that when the text is transplanted into a different language, completely new rules emerge. Both the text and the paratextual material surrounding it are treated in a more liberal way: large sections are omitted even from the main text, and when it comes to the paratexts, new ones are more freely introduced, while the originals are more frequently neglected. ${ }^{87}$ Whereas the Latin Utopia seems to be governed by the original authorial intent of More and his circle, the text begins a new life in the hands of the translators, and each new cultural context appropriates it for its own interests.

The Basel 1524 version is a drastic reduction of More's work: it contains only the second book, and omits most of the paratextual materials (only the map, the Utopian

\footnotetext{
${ }^{86}$ I used the digitised version of the anthology, available full-text through Google Books. Apart from conventional line decorations, the anthology seems to contain no illustrations at all. Source: http://books.google.com/books?id=TYI-AAAAcAAJ, date of access: 27 July 2013.

87 My account is based on the chapter 'The German Translations: Humanist Politics and Literary Journalism' by Trond Kruke Salberg in Cave's book (Cave 2008, 32-46), and (Winter 1978, 28).
} 
quatrain, and the short closing passage are left intact), but at the same time, adds a relatively long preface to the text. Like the preface later, already the title page makes it clear that only the second book of the work is translated. The translator of the work is Claudius Canticula (or Claude Chansonette, cca. 1490 - 1549), who, according to the preface, prepared the publication as a farewell present for the leaders of Basel, where he has been studying since 1517 , precisely at the time of Utopia's publication there. ${ }^{88}$ The preface draws a parallel between Basel and Utopia, both "organised well and justy," and being characterised by a "happy social order". ${ }^{89}$ The most interesting part of the new paratext, however, is the next section, where other "policies" are catalogued and compared to Utopia (and thus, to Basel), of course to their detriment. The text claims that some of these were not just theoretical policies of Socrates, Phaleas, Hippodamus, Minos, Lycurgus and Solon, but were actually put into practice by the Magnesians, the Carthaginians, the Milesians, the Cretians, the Lacedaemonians, and the Athenians, respectively. In Salberg's opinion, here the author of the preface "is not so much using historical arguments as entering into a literary game, quite in the spirit of the Latin paratexts (Cave 2008, 38)." At the same time, the game serves the most serious purposes: it might be a warning for Basel that their city could, like the renowned ancient polities, fall "into such decay that they can in no way be compared to what they were." 90 The most captivating feature of this paratext is that simulates the Utopian game, while

\footnotetext{
${ }^{88} \mathrm{He}$ corresponded with Erasmus, and, besides being a rector at the university, was involved in practical jurisdictional tasks (as "Ratssyndikus" in the city), just like More. He left Basel in 1524 "als Gegner der Reformation." See Wolf ([2013]).

89 “(...) wol und recht gehandhabten gemeinen”, “eins glückseligen Regiments” (Cave 2008, 155).

90 “(...) yedoch synd die dermassen in abnemen gefallen / das sy irem alten wesen in keinen weg zuverglychen synd." Salberg, who provides a detailed account of the historical context of the work, attributes no such counter-exemplary role to the list of ancient policies, although he obviously interprets the preface as a warning for Basel against the possible consequences of the reforms. Cf. Cave (2008, 356, quotation: 156-7).
} 
at the same time it not simply maintains but also profoundly relocates its serious content.

The second German translation (Leipzig 1612) is interesting for other reasons. The translator is Gregorius Wintermonat, and his edition, like Chansonette's, finds the first book superfluous, although this version is less radical, and preserves its beginning and its end. Just like in the 1524 translation, the prefatory letters are completely omitted, yet, a new preface is introduced, and some restructuring (division into chapters, table of contents, running titles etc) also occurs (Cave 2008, 39-40). ${ }^{91}$ The map is also replaced with a simpler one, which is more faithful to the description in the text. The preface is mostly engaged in propagating the high esteem of both Thomas More and his Utopia, with the great names (Erasmus, Froben, Budé and even the previous translator, Chansonette) also mentioned obviously for the sake of their authority. The omission of prefatory material is admitted in the preface, and in one instance, a short passage is even quoted from one of them. The last section of the preface enters into the Utopian game, and elaborates on the question how Utopia was not, since the original publication, been found by the many seafarers. The answer proposed is a Morean mixture of satire and seriousness: probably all the ships that arrived there have sunk, or the people who successfully made there did simply not want to come back from the perfect state. The game is concluded with a rather didactic solution to the riddle: "And finally, the very name Utopia seems to imply that this island may hardly be found (Cave 2008, 167)."

\footnotetext{
${ }^{91}$ Salberg calls attention to the title page, where a curious name is given in the Utopian alphabet, which he finds strange, "since the translation does not include the Utopian alphabet (Cave 2008, 40)". In Winter's bibliography, there is a reproduction of the Utopian alphabet from the Leipzig 1612 edition (Winter 1978, XV). Therefore, the mystery Salberg refers to might have a bibliographical reason: the alphabet is probably missing from the British Library edition used by him.
} 
Therefore, both German translations suggest that the vernacular translations tend to treat the original text in a rather liberal way. Both feature new paratexts, and both omit not only the prefatory letters, but the main text or significant parts of it, too. At the same time, the new prefaces, while readjusting the text for a given historical context (Chansonette), also engage to a smaller (Chansonette) or larger (Wintermonat) extent in the Utopian game of the original prefatory material. This is no doubt due to contemporary notions about the nature of translation, which is "a double process of decontextualisation and recontextualisation," where "doing violence to the original" is inevitable, but it is in ideal case also capable of "enriching the host culture" (Burke $2007,10)$. The variability of this double process is most apparent in connection with the first two English editions, which are on the two sides of a huge rift in English history.

\section{The English Translation}

The first English translation of Utopia appeared in 1551, and its translator is Ralph Robinson, a goldsmith apprentice with education in Oxford, who supposedly translated the work for a haberdasher, George Tadlow. ${ }^{92}$ The translation was published four times until 1650, but for our present purposes, the first two editions, 1551 and 1556 are of peculiar interest. These editions support the idea that vernacular versions of Utopia regarded the paratextual material as more or less optional: the first edition only provides More's letter to Giles, while later versions expand the collection, but for example, the

\footnotetext{
${ }^{92}$ Biographical information is from the ODNB article on Robinson (Bennel 2004).
} 
map and the alphabet is never included. ${ }^{93}$ At the same time, new prefaces are regularly added to the editions.

The differing prefaces in the 1551 and 1556 editions reveal what is at stake in the prefatory material. The preface of 1551 is addressed to William Cecil, "one of the two principal secretaries to the King his most excellent majesty (Bruce 1999, 145)." The second edition, from 1556, however, drops this preface and adds a new one entitled "The Translator to the Gentle Reader" (Bruce 1999, 3). Although one modern editor of Robinson's translation claims that the 1551 preface "was dropped in the second [edition] for reasons that are not clear," there could have been a very obvious reason for the replacement of the original 1551 dedication, and that is the change of regime. Whereas in 1551, the protestant Edward VI was on the throne, the 1556 edition was published under the reign of Mary Stuart.

The first preface is obviously informed by the air of fervent Protestant statebuilding. The reform-minded atmosphere is described with a Lucian anecdote that establishes a link from Robinson to Rabelais (who used the same anecdote in the preface to the third book of Pantagruel) and, indirectly, to Erasmus and More, too (who translated Lucianic texts, although not the mentioned anecdote). The anecdote is the source of an analogy with England, where the writer sees "every sort and kind of people in their vocation and degree busily occupied about the commonwealth's affairs, and especially learned men daily putting forth in writing new inventions and devices to the furtherance of the same (...) (Bruce 1999, 145)." The building of the new (Protestant) commonwealth is, in Robinson's reckoning, fuelled by writers and writings, to which he

\footnotetext{
93 As for bibliographic information, I rely on chapter 5 (The English Translation: Thinking About the Commonwealth) of Cave's book, written by the editor himself (Cave 2008, 87-103).
} 
wants to contribute through the protection and support of William Cecil. Of course, More was not an obvious selection only two decades after his death, and the preface feels the need for apology:

(...) it is much to be lamented of all (...) that a man of so incomparable wit, of so profound knowledge, of so absolute learning, and of so fine eloquence was yet nevertheless so much blinded, rather with obstinacy than with ignorance, that he could not or rather would not see the shining light of God's holy truth in certain principal points of Christian religion; but did rather choose to persevere and continue in his wilful and stubborn obstinacy even to the very death. (Bruce 1999, 146)

Besides replacing the preface, the 1556 edition also translates more of the original paratexts. The preface is much shorter, and devotes just a bit too much space for the conventional modesty (the translation was made hastily, only for a friend, without the intention of printing it), and then again quotes a classical author (this time Terence), this time word-by-word, and in Latin. He provides an English summary of it in the following words:

In which verses the Poete likeneth or compareth the life of man to a diceplaying or a game at the tables. Meaning therein, if that chance rise not which is most for the player's advantage, that then the chance, which fortune hath sent, ought so cunningly to be played, as may be to the player least damage. (Bruce 1999, 3)

Although the burthensome rest of the preface relates this poetic wisdom to the affair at hand (the translation not meant to be published but published), in my opinion, the passage obviously lends itself to a more general interpretation, describing a possible behaviour for Protestants in the time of Mary's attempts at re-establishing Catholicism in the realm. In a way this preface informs the reading of the first preface, too, as the two together suggest that with all the twists and turns in his sentences, Robinson uses 
the prefatorial position for designating the role of the text in the actual historical circumstances. The adjustment is also obvious in the total neglect of More: in 1556, under a Catholic ruler interested in making a martyr of More, there was no need for excuses, and thus Robinson does not say anything at all about him..$^{94}$

Finally, some words about the editions and the style of the translation. According to Cave, the printer of the English Utopia was mostly known for cheap editions of popular works, and he finds that “(...) Utopia re-emerges here at a considerable distance from the circle of Erasmian intimates in which it was originally conceived, and also from the Latin editions (...) (Cave 2008, 95).” Equally interesting and possibly linked to this changed intended readership is the way Robinson performs the translation. His translation is anything but faithful, and received much critique, with one evaluator claiming that "the implications of all that More had to say may very well have escaped him (Binder 1947, 376)." From the perspective of Binder's fundamental classical knowledge, the critique is certainly justified. However, the translation, even if it is unfaithful to the original text, bears special significance for all later utopias. Instead of seeing it as a problem, Robinson's biographer finds merit in the translation's distance from the original, claiming that "his [Robinson's] racy prose is so far from More's original as to constitute a new literary form (Bennel 2004)." Without Robinson's achievement, the next chapter of my dissertation could have been left unwritten.

\footnotetext{
${ }^{94}$ In a similar vein, Cave claims that "the overriding factor determining the context in which the [second] translation was reissued is the abrupt change of regime and of public culture that had occurred with the ascencsion of the ultra-Catholic Queen Mary in 1553 (Cave 2008, 94)
} 


\subsection{Summary}

The preceding investigation into More's much-discussed work attempted at a reevaluation of Utopia on several levels. First, it became obvious that the founding work relies heavily on the conventions of Renaissance dialogues, and closely follows their logical structure, while at the same time, constantly reflects on its own dialogic nature. Second, a thread of literary-theoretical notions has been identified in the paratexts, which suggests that the text is informed by a very consciously developed concept of its own literary character, and that this character, in the authors' intention, should not escape the reader either. Finally, a brief look at later Latin editions and some of the early translations demonstrated on one hand that while the Latin edition could more or less preserve its original form and structure, vernacular versions often radically altered that structure. The translation's prefaces prove that More's text requires very strong recontextualisation when it comes to translation, and the English rendering shows a huge gap between the original and the new milieu of the text, in effect establishing a new, truly English genre. In what follows, the first specimens of this genre, the early modern English utopia will be discussed. 


\section{Dialogue and utopia in the 1570s-1580s: A Pleasant Dialogue Between a Lady Called Listra and a Pilgrim (1579)}

\subsection{The "displaced land" tradition}

Thomas Nashe's picaresque, the Unfortunate Traveller (1594) recounts the travels and misfortunes of a protagonist called Jack Wilton, who encounters Erasmus and Thomas More when he shows up in Amsterdam. Although with this reference we are striding away from the precise subject of this chapter, the way the "superingenious clarke" and the "merrie Sir Thomas More, our Countriman" are invoked is enlightening for that subject too (Nashe 1920, 42). Erasmus appears as the author of the Praise of Folly, whereas More is the writer of Utopia, and no other works are mentioned in either case. The brief passage on More tells a lot about the perception of Utopia and its author at the end of the century:

Quick witted sir Thomas Moore travelled in a clean contrary province, for he seeing most commonwealths corrupted by ill custome, and (...) that in the chiefest flourishing kingdoms there was (...) a manifest conspiracy of rich men against poor men, procuring their own unlawful commodities under the name and interest of the commonwealth: he concluded with himself to lay downe a perfect plot of a commonwealth or government, which he would entitle his Utopia. So left we them to prosecute their discontented studies, and made our next journey to Wittenberg (Nashe 1920, 42).

The short reference to the two eminent humanists aptly reflects what is seen by some as the "central point" of Nashe's book: "the apparent split between rhetorical cleverness and moral action" (Gohlke 1976, 398). This duality will be a fundamental concern, an ubiquitous feature for the texts to be discussed in this chapter: the "first" imitations of Utopia are without exception informed by a strong inclination toward 
moral reform. ${ }^{95}$ Therefore, it must be emphasised that besides the manifest concern with moral issues, Nashe's work is also fuelled by "the desire to engage with literary history," and that "[a]s a satirical prose text, More's text is an obvious precedent for much of The Unfortunate Traveller" (Guy-Bray 2007, 38,41). When someone sets out to imitate More's masterpiece, he is under the influence not only of More's celebrated moral integrity but also of his literary technique. The previous chapter discussed two aspects of the latter in exploring More's use of the paratextual space and the dialogue form - as we will see, many of his achievements in these two areas have been noticed and mimed by the followers.

Nashe's reference, however, is significant from other perspectives as well. In a survey of prose fiction between 1553 and 1625, Hadfield $(1998,135)$ observes that the form was regularly employed "as a vehicle to explore contemporary political problems, invariably setting the individual fiction in question in a distant land or a distant time." Furthermore, he suggests all versions of this tradition descend from More's work, and rely on his "use of travel writing (...) to combine political reflection and fiction" (136)". If More can exert such a profound influence on a genre that was in fact unborn in his own time, one should be prepared to trace the literary influence of Utopia in unexpected places. Searching in such places may help us to relieve the sense of gap that shows between Robinson's first translation from 1551 and the English text (from 1579) that, according to Sargent's bibliography, is the first direct imitation of More's work. ${ }^{96}$

\footnotetext{
${ }^{95}$ Of course, the word "first" should be treated with some reservation. Who was the first to actually imitate Utopia in English is a highly speculative question. However, the pieces to which I refer here as the "first" are those which are the first in the wake of More according to Sargent's bibliography. One could well argue for a much earlier influence, though, as I will also hint at it below.

${ }^{96}$ It must be noted that Winter's Compendium Utopiarum lists at least one relevant English work before 1579, Barnabe Rich's A Right Excelent and pleasaunt Dialogue, between Mercury and an English Souldier, published in London in 1574 (Winter 1978, 40, item nr. 50).
} 
Probably a thorough mapping of this period should be performed in order to better understand the channels through which More's work became so determining for a completely different genre in a completely different time, but here, let me invoke just a few possible examples. As a remarkably early one, there is a curious English poem, contemporaneous with More, which seems to bear at least some connection to the topics discussed in Utopia's first book. Although the modern editor of the Parliament of Birds (c. 1487-1520) is not too enthusiastic about the literary qualities of the work (“Extravagant claims for literary excellence (...) would be inappropriate”), for our present purposes, it is noteworthy for both form and content (Andrew 1984, 26). As for the former, the poem is a literary debate, which is regarded - as we will soon see - by many scholars as an important link between ancient Greek and Latin and early modern English dialogues. ${ }^{97}$ Secondly, even if the rendering is by nature (a mock parliament of birds) satiric, the topic itself seems to be more serious, namely, the question of counsel. ${ }^{98}$ This, of course, reveals a shared interest between the poem and Utopia, where one of the central issues is precisely the debate on counsel, and even if in an allegoric way, the poem evokes the same courtly milieu that plays such an important role in Book I. Hardly an utopia, the poem uses displacement (into the realm of allegory) and satire with the aim of transmitting a politico-philosophical message, which is not that far from More's approach.

Similar interest toward counselling and the ways of governance, or more generally toward the cause of the commonwealth can be registered in works of vastly

\footnotetext{
${ }^{97}$ According to Andrew, the other important generic tradition informing the text is the "bird lore," which seems to be less relevant for the present discussion (Andrew 1984, 31).

${ }^{98}$ For a brief introduction to the text, see Bryson (2007). Among others, he identifies the following topics in the poem: counsel, England, law, social relations. While Bryson claims that Chaucer's Parliament of Foules might have inspired this text, Andrew doubts direct influence for lack of evidence (Andrew 1984, 34).
} 
different nature. Only 8 years after the first edition of Robinson's translation, Johannes Ferrarius Montanus' Tractatus de respublica bene instituenda. Das ist ein sehr nützlicher Traktat vom Gemeinen Nutzen was published in English, with a dedicatory epistle to Elizabeth I. ${ }^{99}$ Although the book is by no means a utopia, it is about "the good orderynge of a common weale," and as such, necessarily touches upon some of the matters discussed in More's book, often recommending specific legal cures for social problems (Ferrarius 1559, title page). ${ }^{100}$ One should also remember that Robinson's first preface, written during Edward's reign hits a very similar tone: “every sort and kind of people in their vocation and degree [are] busily occupied about the commonwealth's affairs (Bruce 1999, 145)". It is beyond doubt that the motifs behind the two works are similar, and that similar issues govern the use of the "displaced land" tradition in the prose fiction works surveyed by Hadfield. ${ }^{101}$

However, a more definite similarity is revealed when one also pays attention to the generic background of Utopia, as identified in the previous chapter. The genre of

\footnotetext{
${ }^{99}$ Johannes Ferrarius Montanus (1485/6-1658): German jurist, theologian, and writer, disciple of Philipp Melanchton, leader of the University of Marburg (Muther [2013]). The work was translated by William Bavande, about whom not much is known save for this translation (Kennedy 2004).

${ }^{100}$ Nonetheless, the difference of emphasis is clear already on the title page ("not as the Philosophers in their vaine tradicions haue deuised, but according to the godlie institutions and sounde doctrine of christianitie"), and later in the definition of commonwealth as well:
}

Which [common weale], therefore it shall be conuenient to our purpose to define, thus: An assemble, and repaire of men lawfully gathered, to liue well and blessedly, that being thereunto godly brought by, thei maie looke for euerlastyng life (Ferrarius 1559, D2v).

${ }^{101}$ Of course a long list of commonwealth-related works could be drafted here. Hadfield enumerates a good deal of them, identifying a group of writers who pursued a political career besides writing. Although he acknowledges the importance of translations, Ferrarius is not mentioned. See Hadfield (1998, 137-8). The question is no doubt connected to and its complexity is multiplied by the question of Elizabethan republicanism. For an account with an overview of works and translations related to the matter, and with occasional references to Utopia, see Peltonen (2002). Kendrick offers a powerful comparison between utopia and two basic works (Thomas Starkey's A Dialogue between Pole and Lupset, c. 1529-33, and Sir Thomas Smith's A Discourse of the Common Weal of England, 1549) pertaining to the question of republican thought, and demonstrates the affinity between utopian and commonwealth writing (Kendrick 2004, esp. ch. 3). 
English dialogues is significantly and ubiquitously present in the literature of the time, so it is quite logical that eventually it would combine with the similarly permeating "displaced land" tradition. This chapter sets out to explore the moment when, probably for the first time, these two traditions converged, producing the text in focus here, Thomas Nicholl's A Pleasant Dialogue betweene a Lady called Listra, and a Pilgrim. Concerning the Government and common weale of the great province of Crangalor (in two parts, both in 1579; henceforth: A Pleasant Dialogue). For a broader context, I will also refer to two similar texts from the period: Thomas Lupton's Siquila. Too Good to be True... ( $1^{\text {st }}$ part $1580,2^{\text {nd }}$ part 1581$)$, and probably the best known of this triad, Phillip Stubbes's The Anatomie of Abuses... (2 parts, both published in 1583), and I will suggest that these works are similar in many surprising ways. Relying on them, a number of exciting questions can be conceived. What happens to the original form of Utopia when it is transposed into a genre which has become outstandingly popular, but which has also experienced significant alterations since More's time, not to talk about the profound change of language from Latin to English? To what extent are the first imitators aware of More's use of the dialogue form, and are they sensitive to the theoretical problems discussed in their pattern? Do they follow the unique paratextual configuration of Utopia? When they make use of the fictional potential of the form, are they driven by similar motives? Hoping to offer more detailed answers, this chapter argues that in the eyes of the first successors, utopia was not simply a convenient tool for the displaced discussion of sensitive issues, but also a system of palpable literary conventions, but a system that they remarkably fashioned to their own ends. It was, nonetheless, not the only system of conventions governing A Pleasant Dialogue, and the two other works. The so-called Tudor dialogue enjoyed enormous popularity in the $16^{\text {th }}$ century, but if Hadfield $(1998,134)$ muses over the question whether it is "still true 
that prose fiction is the poor relation of poetry and drama as far as modern critical interest is concerned," the question is equally relevant in the case of dialogues. Therefore, it is inevitable to begin by taking a look at the way Tudor dialogue is treated in secondary literature.

\subsection{Tudor dialogues: a problem in literary history}

As far as English literature is concerned, it was probably Dryden who first realised the peculiar position of dialogues within the broader field of literary studies. In an edition of Lucian, he added the following remark:

I will not here take notice of the several kinds of dialogue, and the whole art of it, which would ask an entire volume to perform. This has been a work long wanted, and much desired, of which the ancients have not sufficiently informed us, and I question whether any man now living can treat it accurately. ${ }^{102}$

The quotation regularly appears in studies concerned with the history of early modern English dialogues, and its underlying sentiment is predominant in almost all related contributions of the $20^{\text {th }}$ century. ${ }^{103}$

Dryden's and the later referrers' desire for an overview of the genre's history is reasonable enough if one considers the sheer number of dialogues produced in the $16^{\text {th }}$ $17^{\text {th }}$ century. Even if the specific numbers often differ, most critics agree in the general proportions, and estimate that around or more than 250 dialogues were produced in the

\footnotetext{
102 The Works of Lucian (1711) quoted by Purpus $(1950,47)$.

${ }^{103}$ For a thorough review of this rehabilitative trend of scholarship, see Deitch (1998, vii-xi). She calls attention to the many repetitions in the works, and finds that their authors "only just scratched the surface".
} 
sixteenth century. ${ }^{104}$ My own research in the Early English Books Online database returned 241 items from the earliest times till 1600 . On the other hand, scholarship has never reflected these proportions, and the retrospective look at $20^{\text {th }}$ century contributions to the field of dialogue studies allows for little enthusiasm: "Since [Merrill] published The Dialogue in English Literature just two other monographs, a few chapters in general studies, a handful of Ph.D. dissertations, and a small number of scholarly articles specifically on early English dialogue literature have appeared" (Deitch 1999, 46-73).

Fortunately, the last few decades brought important positive changes in this regards, and many more recent works point into a new direction where the rehabilitation of the genre is no longer deemed necessary, and its legitimacy taken for granted, more specialised studies can be performed. ${ }^{105}$ Before applying some of these newer results on the study of A Pleasant Dialogue, a quick review of the historiographical problem is inevitable, as I am convinced that it is at least partly responsible for the long neglect of some sixteenth century dialogues with utopian topics.

The classic $19^{\text {th }}$ century comprehensive (all-European) overview of the history of dialogues, Hirzel's two-volume work makes only passing reference to English dialogues around the time of the Reformation, and it is fuelled by both national and confessional bias:

\footnotetext{
${ }^{104}$ Deakins talks about 230 dialogues in the sixteenth century, whereas Deitch $(1999,46-73)$ remarks that „on the basis of numbers alone dialogue would rank higher than epic and perhaps even pastoral or tragedy".

105 The pinnacle may be Zlatar's recent book, where a strictly delimited subgenre (Protestant polemical dialogue) is identified, and some of its representatives are discussed in detail. To be referred below.
} 
Im Anschluss an die deutsche Literatur hat auch das England der damaligen Zeit eine Reihe von Dialogen producirt, aber weder so ursprünglich noch so massenhaft. Man möchte sagen, dass auch hierin der gedämpfte Charakter der englischen Reformation zum Ausdruck kommt. (Hirzel 1895, 393)

The account deals somewhat more extensively with dialogues from the seventeenth century, identifying a rise in the form's popularity around the Civil War, and mentions by name several seventeenth century authors (Bacon, Raleigh, Dryden) but not one from the sixteenth century (Hirzel 1895, 398-9).

If a German author fails to make a real case for the English dialogue, the probably first overview of the English corpus, Merill's account also expresses only refrained enthusiasm for the form, or at least for its English manifestation. Starting from the distinction between Plato (who made a true 'form' from dialogue) and Cicero and Lucian (for whom it was merely a 'method'), she is never able to find a perfect realisation of the ideal Platonic form in later times (Merrill 1911, 11). Transmitted by early Christian dialogues, she finds that in medieval times the tradition of the ancient dialogue persisted in the form of catechisms and debate poems (Merrill 1911, 18-30). From the sixteenth century, Merrill emphasises the role of the polemic dialogues, while she also enumerates a number of other genres where an influence of the dialogue is significant, including interlude/drama, eclogue, and romance (Merrill 1911, 30-38). The overarching interest in genres other than the dialogue itself is always manifest in Merrill's account, and it is probably responsible for the discouraged conclusion of the work:

It is true, at least of English dialogues, that they are (...) parts rather than wholes, and therefore not products of the highest art. (...) Thus they are of foreign tone, and somewhat ill at ease on English soil. (Merrill 1911, 130) 
In her final lines, she is expressing hope that one day a great English dialogue writer would come, who could write perfect Platonic dialogues, and thus would equal Shakespeare who "widened our conceptions of the drama" (Ibid.). ${ }^{106}$ Although her selection of polemical dialogue as the most characteristic of the $16^{\text {th }}$ century English corpus makes sense as far as A Pleasant Dialogue is concerned, she unfortunately fails to discuss either that, or any other dialogues of the "displaced land" tradition. ${ }^{107}$ Besides, she makes but a passing reference to Utopia (Merrill 1911, 129).

If Merrill put too much emphasis on the ancient models of dialogue writing, and closed her book in the hope of living to see the birth of an English Plato, a similar attitude pervades Wilson's book, too, which is probably the next published monograph on the genre's history. Although the subtitle of his book (The Formation of English Renaissance Dialogue) suggests a change of scene, this is not completely true. The author devotes serious energies to the aesthetic analysis of the ancient form, offers a comparison between Platonic and Ciceronian dialogues, and then looks at the way humanists made use of the form. This leaves only limited space for the discussion of English dialogues, and only authors with strong ties to humanist culture (Elyot, Ascham and More) are discussed. The author's preoccupation with the classical models, and their humanist imitations is also clear when he talks about "the rise of the dialogue in the half century beginning in 1475 " (Wilson 1985,52 ). This, of course, is only true to

\footnotetext{
${ }^{106}$ Drama is a - not necessarily fortunate - reference point for Hirzel $(1895,389)$, too, who claims that in Elizabethan times, drama in fact "absorbed" the dialogue form. The simultaneous popularity of drama, together with the absence of a "big" English dialogue author might be the reason leading to the "exclusion of these intriguing works from the canon of English studies (Deitch 1999, 47)." Of course, there is one big author, Thomas More, but comparing later dialogues to his works is misleading or at least unfair according to Warner (2004, 63-4).

${ }^{107}$ It should be added that polemical dialogues were also discussed a few decades earlier by Herford, as an important aspect of German literature's impact on English. In his second chapter, Herford obviously refers to what is termed by more up-to-date criticism as 'Reformationsdialog'. Cf. Herford (1886, ch. 2., esp. 26-31).
} 
the Latin humanistic dialogue, as the English vernacular production only begins to step up precisely at the end this period, in the end of the 1520s (as seen in Figure 2).

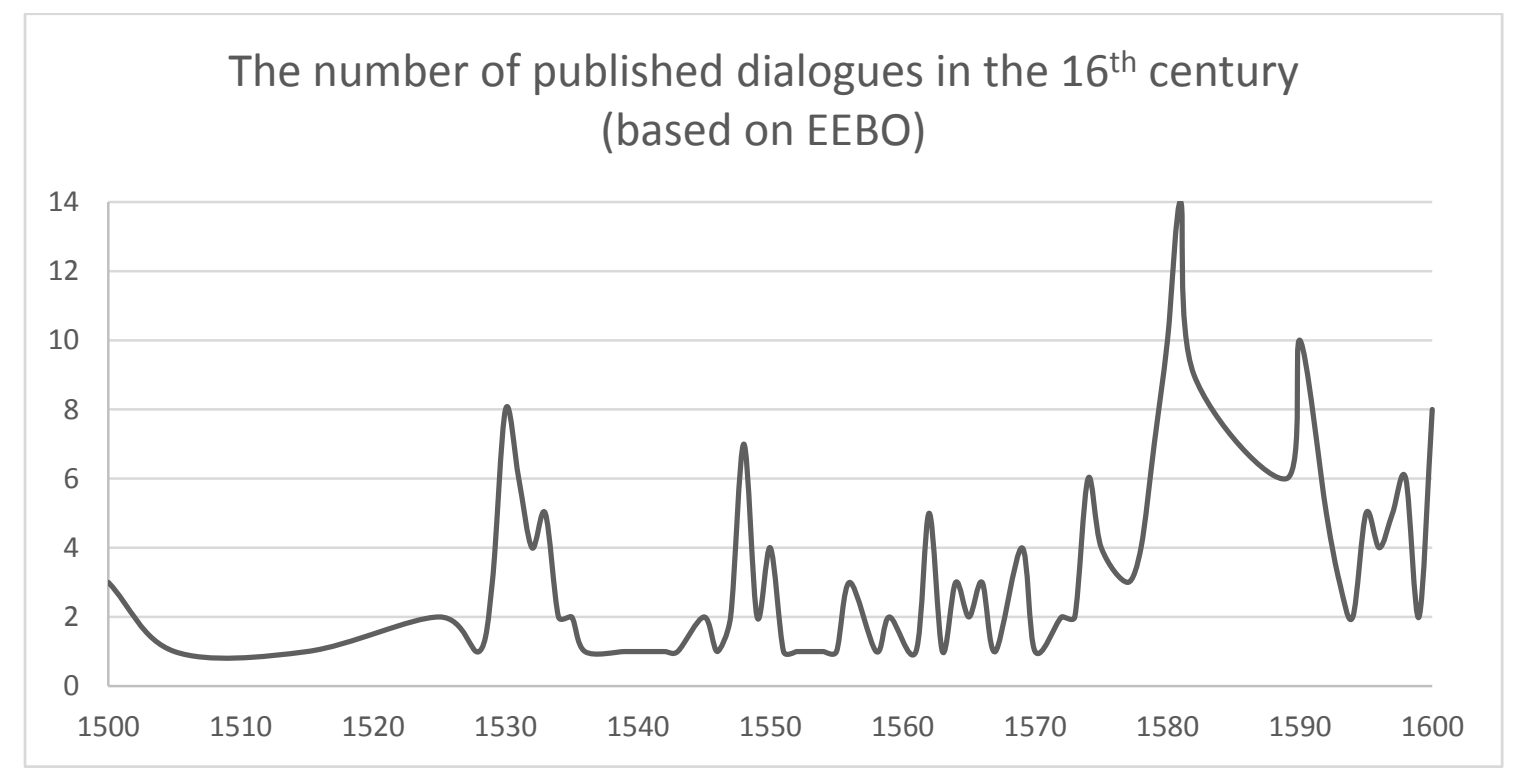

Figure 2.

Nonetheless, Wilson's initial observations about the medial nature of the dialogue are truly exciting: in his view, dialogue is "a partial imitation, and hence a medial art: an incomplete fiction" (9). However, by the end of the book, it becomes clear that this medial nature should be understood in a peculiar way, in the sense that "dialogue is not fully detached from the mental processes of its author" (180). As interesting from a theoretical point of view as it is, this internality is not necessary helpful when we are dealing with the history of the genre.

Deakin's article, written decades after his dissertation on the topic, sheds light upon many questions arisen by the two monographs mentioned. He drafts an inventive model of English dialogues, where two fundamental types are distinguished, out of which the first more or less fits the requirements drafted by the Italian theorists. Significantly, he thinks that the best example for such a rule-conforming dialogue is More's Utopia, and in his opinion, the great majority of English Tudor dialogues 
belongs to a different family, which he calls "anti-genre". ${ }^{108}$ In his evaluation, only a handful of the more than 200 Tudor dialogues pertain to this classical type, whereas the others are handling the generic requirements more freely, neglecting the ideals of decorum, and they regularly "assimilate other literary genres" (Deakins 1980, 21). There are several observations to be made here. First, if we take a look at the authors discussed by Wilson, we have to realise that 2 out of them are classified by Deakins as the writer of "genre" dialogues. Furthermore, Deakins claims that "the writers who composed anti-genre dialogues did not come from established families," but claims that Ascham was on the upper end of this social strata, so in fact, the third one is also among the better-dressed dialogue writers (19). This suggests that critics who are, like Merrill and especially Wilson, more interested in dialogues closely following the ancient model, tend to disregard about $95 \%$ of the corpus. Even if the term "anti-genre" may sound a bit derogatory, Deakins has many valuable observations concerning this type, many of which also relate to A Pleasant Dialogue, especially the "self-consciousness about language," and the "verisimilitude of presentation" (23).

The historian Burke's article is again a valuable contribution to the case, even if its scope is wider, and discusses dialogue as a European phenomenon. Nonetheless, many of his insights might help us to better understand the immense popularity of the genre in the $16^{\text {th }}$ century in England. In his catalogue of such factors, besides the impact of printing, the general revival of rhetoric, and the popularity of Lucian, the most important for the present discussion might be the point that dialogue is capable of treating serious matters in a light-hearted tone (Burke 1989, 7). This duality was obviously an inherent structural element in Utopia, so it is one of the most exciting

\footnotetext{
${ }^{108}$ My account of his model is based on Deakins (1980, esp. 15-6).
} 
questions how this feature is exploited when utopia and dialogue meet for the first time in English.

Deitch's dissertation offers one of the most sensitive inquiries into the problems concerning the history of English dialogues, and it also refers to A Pleasant Dialogue. She provides an impatiently critical survey of previous contributions, a background against which she tries to defend the legitimacy of the genre. In her opinion, "English dialogues are not violating so-called "rules" but tapping into native and European traditions of dialogue writing which were transmitted and practiced throughout the Middle Ages and into the Renaissance" (Deitch 1999, 46-73). And how should we approach these dialogues once we have realised that they are an independent species? Deitch finds that previous attempts, which yielded different classifications of the same material show that formalistic inquiries are doomed to fail, and they are plagued by "overlap, repetition, and contradiction" (18). Equipped with the armoury of both early modern and modern literary theory, she engages in a lengthy battle, but eventually succeeds, and thus liberates dialogue from the long-standing mis-association with the most oppressive of all genres: the drama. ${ }^{109}$ Her anti-Derridean genre-theory emphasises the unescapable natural tendency of genres to mix with each other, a phenomenon often discussed in utopian studies, too, and particularly relevant in the case of A Pleasant Dialogue. ${ }^{110}$ In her case studies, she focuses on the pieces' relation to dialectic or

\footnotetext{
${ }^{109}$ Her detailed theorising about genre is explicitly launched with this purpose: "After establishing a working definition of genre via a discussion of current genre theory, I will attempt to lay to rest the primary misconception of dialogue as a subspecies of drama, which has been hindering study of English dialogue" (Deitch 1999, 57).

${ }^{110}$ In Deitch's view, drama is "encumbering" for other genres - in England, because of the influence of Shakespeare, in Europe because of Aristotle's Poetics; cf. Deitch (1998, 58-63, 78-9). On genre in utopian studies, see chapter 1.3 Tradition, genre, literature?
} 
rhetoric. ${ }^{11}$ During the discussion of works predominantly engaged in the art of persuasion, she tries to defer readers from reading Spenser's A View on the Present State of Ireland (1596) by way of identifying the main speaker with Spenser. Here, she puts forward an interesting assessment:
(...) from a literary perspective we must consider More's Utopia as a controlling force in English dialogue literature of the century. There were many imitations or Utopia-influenced dialogue works. (Deitch 1998, 239)

The remark is not only interesting because of the examples provided (Stubbes' Anatomie of Abuses, Lupton's Siquila: Too Good To Be True, and A Pleasant dialogue). In the opening of this chapter, I have quoted Hadfield, who claimed that Utopia had a profound impact on a subgenre of prose fiction. Now we read that Utopia is a "controlling force" within the huge body of dialogic works. Utopia is one of the examples applied by Sir Philip Sidney in the first English apology of poetry. The $500^{\text {th }}$ anniversary of the birth of Utopia approaching, maybe it is time to re-evaluate the literary influence of the masterpiece.

Deitch thus established a link between dialogue and utopia, and a deeper exploration of this connection was promised by the 2004 volume edited by Heitsch and Vallée (2004), which devotes three articles to the topic. Out of these, Vallée's insightful analysis of Utopia has been cited in its due place, while Chordas was cited in the introduction with her remarks on the generic nature of utopias. Her contribution in this volume has later become a chapter of her book, and the dual (utopia-dialogue) perspective reveals interesting connections. According to Chordas $(2010,17)$, even in

\footnotetext{
111 The basis of the EITHER/OR distinction is that although she acknowledges that both are important elements of dialogues, which "are intertwined in any given case," she also thinks that every work privileges one of them, according to its primary aim (teaching/persuading). Cf. Deitch (1998, vii-xi).
} 
utopias which are not written as dialogues, "the form continues to haunt," and she claims that this is due to the common "quasi-fictional" status of the two. It is also important for our present purposes that in her approach, the "general distrust against imaginative literature" (18) is also an important aspect of both early modern utopia and dialogue. The third article from the volume, Warner's will be later cited in more details, as it offers a fruitful new approach to the genre, an approach that seems particularly useful for A Pleasant Dialogue and the other utopian texts of the times.

As probably the most recent monographic contribution to the field, Zlatar's book on Protestant polemical dialogues has an eminent place in this review. This book is not only paradigm-shifting because of the selection of texts (moving away from the humanist to the non-humanist vernacular tradition), but also because of its approach. Fuelled by a supposed recent turn in literary history which tries to reduce the gap between "religious" and "proper" literature, Zlatar pursues an "unashamedly interdisciplinary project, situated between cultural history and historicist literary criticism" (Zlatar 2011, 7). ${ }^{112}$ She warns that a great many Elizabethan dialogues could be labelled as 'religious', so one inevitably has to operate with narrower categories like "Protestant polemical" dialogue, which is her means to exclude, among other categories, "works targeting commonwealth issues," where A Pleasant Dialogue is one of the examples (9). Besides the open-minded approach to a carefully selected corpus, the other great achievement of Zlatar is the way she resuscitates a connection almost completely lost in the $20^{\text {th }}$ century. At the end of the $19^{\text {th }}$ century Hereford already

\footnotetext{
112 The main inspiration for her approach is Cummings' book, which begins with a prologue arguing for the necessity of doing away with the distinction between early modern religion and early modern literature, and the marginalising term "religious literature". As he puts it: "Without reference to religion, the study of early modern writing is incomprehensible. (...) Writing is not accidental to the history of religion, since belief and dogma are both mediated by a linguistic and literary process. (...) Without reference to writing, the study of early modern religion is incomprehensible (Cummings 2002, 6)."
} 
noticed that one of the flourishing areas of early modern German-English literary relations is witnessed precisely within the dialogue genre. Thus, one can only welcome Zlatar's desire to "set the English publications in the context of the polemical dialogues of Lutheran Germany and Calvinist Geneva, and discuss English translations of key Lutheran and Calvinists texts" (6-7). Another central point is the role attributed to fiction, which serves in these dialogues, in her view, as a means to facilitate the underlying edifying and converting purposes of the work, while at the same time, it was also highly useful (and important) in evading the censors (7).

This is the critical background against which A Pleasant Dialogue is to be read in the next section. The most important aspect of the connection between utopia and dialogue, according to this review, is the role fiction plays in both of them (as clear from Chordas's and Zlatar's opinion), so it will be a central concern for our discussion, too. ${ }^{113}$

\footnotetext{
${ }^{113}$ Although it is not directly connected to the inquiry performed here, a related linguistic project should be at least briefly mentioned. The Exploring spoken interaction of the Early Modern English period (1560-1760) project was a research project at the Department of English at the University of Uppsala. Led by Merja Kytö, Terry Walker, and Jonathan Culpeper, the project is interested in the dialogue genre because it considers it capable of giving some access to the spoken English language of the early modern era. The project was complemented by the Corpus of English Dialogues 1560-1760 project, which is a gigantic digital repository of English dialogues. For an early draft of the project, see Culpeper and Kytö (1997). The project was concluded with an immense volume appealing to linguists (Culpeper and Kytö 2010). The corpus itself, however, might also be helpful for literary scholars, even if the text in the case of A Pleasant Dialogue, for example, is full of unmarked omissions, and only covers the first part of the book. See Kytö and Walker (2006) for a guide to the corpus, which is accessible through the University of Oxford Text Archive, under ID 2507 (a free permission for access is necessary): http://ota.ahds.ac.uk/ (date of access: 20 Sep 2012). In addition, see the short project description at http://www.engelska. uu.se/Research/English_Language/Research_Areas/Electronic_Resource_Projects/A_Corpus_of_English _Dialogues/ (date of access: 10 Aug 2013).
} 


\subsection{A Pleasant Dialogue}

\section{Authorship and Textual Introduction}

The title page of A Pleasant Dialogue gives no clue about the author of the text, but includes other important information:

A pleasant Dialogue. betweene a Lady called Listra, and a Pilgrim. Concerning the gouernment and commom weale of the great Prouince of Crangalor. (Nicholls 1579a, A1r)

Not reproduced here, the different parts of the title are set in smaller and smaller type, making the first two lines, including the phrase "pleasant dialogue" particularly emphatic. It should immediately be added that the above title is only related to the first part of the publication, as it in fact consists of two parts, with "separate dated title page and register". ${ }^{114}$ The title page of the second part runs as follows:

The second part of the painefull Iorney of the poore Pylgrime into Asia, and the straynge wonders that he sawe: Both delectable and profytable, in sequell of the lytle Dialogue, betweene the Lady Lystra, and the same Pilgrime. (Nicholls 1579b, A1r) ${ }^{115}$

As an early observation, it should be noted that while the typography of the two title page variants is almost identical, the second version uses the word 'dialogue' only in reference to the first part of the book. A shift of focus is suggested by this rearrangement: while the first part is a dialogue between a lady and a pilgrim, the

114 Online ESTC entry (http://estc.bl.uk/S110071, date of access: 25 June 2013). In STC (2nd ed.), the work is registered under nr. 18335.5. Considering that the two parts appeared in the same year, they were probably intended to be bound together, but my sources for the background of the work are unclear in this matter.

${ }^{115}$ Henceforth I use the following format for reference: part number/signature ("I/A1r" in this instance). 
second promises to deliver the "painefull Iorney" of the pilgrim. This will be quite important in the discussion of the work, but first, a few words on authorship.

Although neither title page provides the author's name, both parts end with the initials 'T. N.' Following up this lead, the question of authorship has been convincingly settled by Shrank, who claims that Thomas Nicholls (1532-1601) wrote the dialogue. ${ }^{116}$ Her attribution is based on 3 things: 1) Nicholls's possible personal connections to the dedicatee of the work, 2) other travel-related writings published by Nicholls in the 1570 s, 3) certain thematic units in the dialogue which might have been inspired by his own experiences. I agree with Shrank that there is a strong interplay between Nicholl's personal history and certain parts of A Pleasant Dialogue, and this connection might also help us to find the proper place of this dialogue among similar contemporary works. Therefore, a short summary of Nicholl's life is justified not only by his almost complete obscurity, but also by our interpretational interests.

In what sounds like a mordant act of generalisation, Deakins claims that the author of anti-genre dialogues are "from humble stocks," "learning Latin in one of the new humanist grammar schools," and career-wise they are on one hand self-made men, on the other, they are dependent from their patrons (Deakins 1980, 19). To some extent, the description fits Nicholls, too, who started out as a mercer apprentice, but later became a secretary to the Muscovy Company. ${ }^{117}$ Afterwards, he became an agent for the company in Tenerife, bringing a turn in his life which might also shed light upon the

\footnotetext{
116 The best introduction to the text (and in fact, the only one with at least some details) is only available online, via the University of Sheffield, Humanities Research Institute's Origins of Early Modern Literature database (Shrank 2007).

117 Biographical information are from the ODNB entry on Nicholls (Baldwin 2008). Note that there is another Thomas Nicholls in the ODNB from roughly the same time, who was also a translator. However, Shrank's attribution, as well as the numerous biography-related pieces in his writing clear all doubt that the "shipowner and translator" is the author, and not the "translator".
} 
motifs of his work. During an unfortunate dispute on commerce, Nicholls offended a notary of the place. Without going into the details, it is definitely important that he was eventually cited before the Inquisition with accusations of heresy. For years, he was confined in Spain, taken from one prison to other, but after he returned to England, in 1570 he received a small rectory for the trials of faith he had to suffer. Significantly, seven years later he lost the same rectory "for his extreme Calvinist preachments" (Baldwin 2008). In the 1570s, he published a number of translations, and these works are quite similar to each other in at least two respects: their title always includes the adjective „strange,” „pleasant,” „delectable,” or a free combination of them, and their subject is usually some distant country. ${ }^{118}$ Interestingly, Zlatar $(2011,24)$ reports the use of the phrase 'pleasant' in many of the polemical dialogues she reviews, and claims that it does not simply refer to "fictional delight, [but] it can also be connoted as humorous or satirical". This, and the Puritan zeal of the author brings the text closer to the polemical dialogues, while the rest of the titles, together with Nicholls's later affiliation with Richard Hakluyt, establishes a link with the travel literature of the time. ${ }^{119}$ It is also important that the merchant relied on the translation work because he got tangled in difficult, debt-related legal matters, probably arising from his previous affairs in Spain, and he eventually got into the debtors' prison with his wife. No wonder that legal

\footnotetext{
${ }^{118}$ Baldwin (2008) mentions the following works: The Pleasant Historie of the Conquest of the West India, now called New Spayne (1578), The Strange and Marvellous Newes Lately Come out from the Great Kingdome of Chyna (1578), A delectable dialogue wherein is maintayned a pleasant dispatch between two Spanish gentlemen concerning physick and phisitions (1580), The strange and delectable history of the discoverie and conquest of the province of Peru, and the South Sea (1581) A Pleasant Description of the Fortunate Islands called the Islands of Canaria (1583), Pleasant Historie of the Conquest of the West India (1599).

119 His Pleasant Historie of the Conquest of the West India made its way into Hakluyt's Principal Navigations. See Baldwin (2008).
} 
representation and the material conditions of incarceration are of central concern in $A$

Pleasant Dialogue, too.

Moving from the author to the text, the following table provides a structural overview of it (treating the two parts as one single publication):

\begin{tabular}{ll}
\hline \multicolumn{1}{c}{ Paratext nr. } & Description \\
\hline 1. & Title page of part 1. \\
2. & Dedication \\
& Address: To the Worshipfull, Maister Edward Diar, \\
& Esquier: Listra wisheth prosperity. \\
& Salutation: "Your louing friend Listra, of Corinth" \\
3. & Caption: 'The Dialogue'
\end{tabular}

Main text of Part Beginning: narrative retelling how Listra and the Pilgrim met. 1. Then a change to dialogue form, pursued until the last pages.

End: switching back from dialogue to narrative form, retelling how Listra hosted the pilgrim in his house, and gave him money for his future travels, on the condition that he would tell "all strainge things, that he should heare or see in his pretended journey. (C2r)"

4. $\quad$ Verse dialogue between the book and the pilgrim

5. Caption: FINIS. T. N.

6.

Title page of part 2.

7.

\section{Dedication}

Address: To the right Worshipfull Master Edward Dyar. \&c. The poore Pylgrime wisheth felycitie

Salutation: "Your Worshippes most humble, the Poore Pylgrime"

8. $\quad$ Verse dialogue between the book and the pilgrim

9. Caption: The Returne of the poore Pylgrime out of Asia, unto Corinth.

Main text of Part Beginning: narrative retelling that five years later the Pilgrim 2. returned to Corinth and visited Listra once again. Then a change to dialogue form.

10. Caption: The beginning of the Pylgrimes iorney into Asia.

Main text of Part The dialogue is clearly dominated by the Pilgrim, and thus the 2. continued book reminds more of a travel account than an actual conversation. Listra's role is restricted to praising what is told by the pilgrim.

Ending: switching back to narrative form. The pilgrim sets out on a newer journey, Listra bids farewell. 
11.

Caption: FINIS. T. N.

3. Table The structure of $A$ Pleasant Dialogue (1579)

At first glance, the work does not even come near the paratextual complexity of More's text. Even if the two parts are treated as one (as they, in my opinion, should be), the total number of paratextual elements is only 11 , and then it might be somewhat permissive to treat single (but important!) captions as separate paratexts. However, the first glance should not deceive us - A Pleasant Dialogue has quite a few surprises for us in stock, as we will see in the next subchapter.

\section{Paratexts and the use of the dialogue form}

A Pleasant Dialogue is seldom mentioned in utopian studies, although More's book had an "obvious influence" on the work (Shrank 2007). In an early article, Sargent $(1976,276)$ refers to it briefly among the "four little known utopias of the time," which all share the general characteristics of sixteenth-century utopias: they are Christian, hierarchical, focus on the necessity of central control over people (who are by nature weak), and their most important requirement against women is obedience. ${ }^{120}$ In another article on the concept of families in utopias, he emphasises the patriarchal, authoritarian family model in works of the sixteenth century, including A Pleasant Dialogue (Sargent 1983, 109-110). The annotation in his later bibliography stresses more or less the same points:

Small town of good Christians. Emphasis on piety, equity and honesty. There is a godly prince, humble nobility, obedient citizens and a good clergy (Sargent 1988, 1-2).

\footnotetext{
120 The „four" utopias are in fact only two: the first and second part of A Pleasant Dialogue, and the first
} and second part of Lupton's Siquila, Too Good to be True (to be discussed in chapter 3.4). 
The great monographs on English utopias seem to completely ignore A Pleasant Dialogue. Even Davis, who makes a brief reference to Lupton, fails to discuss the work, but it is also absent from the Manuels' book. ${ }^{121}$ The only useful, thought-provoking comment on the text is in an article on the Tudor dialogue, written by the abovementioned Deitch. She establishes a link between alterity and the dialogue form: the dialectical nature of dialogues makes them a "locus of the construction of difference" (Deitch 1999, 49). From this perspective, she finds it particularly distressing that "the radical representation of antithetical or oppositional identities (...) seems to be missing in Elizabethan inflections of the genre" (52). The only exception is precisely the type of texts which A Pleasant Dialogue represents, those which through the fiction of the displaced land transmit "[t]he culturally distant other," and "cast alterity as the absented object of discourse by in-group interlocutors" (53). In her summary, such works criticise "English society for not living up to its potential as a Christian commonwealth" (54). Besides all the inspiring ideas, it is beyond comprehension why A Pleasant Dialogue is not mentioned when Deitch reviews the few dialogues of the time with female interlocutors. Shrank's overview and description of the text is the most recent, and probably the most valuable source of information on the text. Besides all the bibliographic and biographic records, her entry also includes a summary of the text, and in many instances, it provides hints for further research, to which I will refer in their due place. This is, then, the not too extensive critical background for the discussion of the text.

${ }^{121}$ For the reference to Lupton, see Davis $(1981,29)$. 
One of the main concerns in my reading of A Pleasant Dialogue is the actual extent to which it is aware of the subtleties of More's work. I have already noted above some important aspects of the two title pages, so let these serve as our starting point here: whereas the emphatic phrase in Part I is "pleasant dialogue," there seems to be a shift of focus in the title page of Part II, which emphasises the words "painefull Iorney". In my opinion, this change, together with some other adjustments, have serious consequences on the connection between the two books.

Part I is a proper dialogue, and it wants to appear as such - hence the emphatic phrase on the title page, and the caption/subtitle right before the main text, which is quite brief: "The Dialogue" (II/A3r). Furthermore, the figure of Listra seems to be prioritised: not only does she have a name (in opposition to the Pilgrim), she is also the first to be mentioned on the title page, and in the main text itself, Listra is the first speaker. During the flow of the conversation, she speaks significantly less than the Pilgrim, yet she has a central role: in fact, the whole dialogue is structured around her elaborate questions and perceptive comments, like the ones below:

Then how dooth the poore folke obtaine Justice against the riche and mightye? (I/B1r)

But how are criminal matters decided? (I/B3r)

I haue father Pilgrim throughly understood all your talke. But now I pray you how dooth the Notaries, Skiueners, and such like officers use themselues. (I/B5r)

What about Part II? The title page reverses the order, and Listra disappears almost completely: she is mentioned only in passing, within the reference to the first part. The caption/subtitle also changes radically: "The returne of the poore Pylgrime out of Asia, unto Corinth," then a few pages later: "The begynning of the Pylgrimes iorney into Asia" (II/A4r, B1v). These also suggest a shift of focus, and it seems that the 
Pilgrim's travel account becomes more important than the ongoing conversation. This impression is reinforced by one decisive change in Part II. While the addressee of the dedication is the same "extrafictional" Edward Dyer in both cases, the first dedication is signed by Listra, while the second by the Pilgrim. Which means that both are dedications to a real person by one of the fictive characters of the work! ${ }^{122}(2007)$ This is exciting enough in itself, but it should be registered only as the part of a wider rearrangement within the two books. The conversational aspect is less significant here, and at times, the Pilgrim completely appropriates the textual space for pages. Listra's role is systematically restricted: she simply adds some affirmative or praising remarks to the actual land or city described by the Pilgrim. For example, after a several pages long (B6r-B8v) description of the city of Cananor by the Pilgrim, all Listra can say is "O charitable people, I reioice to heare of theire liues in faith" (B8v).

Based on the above initial observations, I claim that the text by-and-large follows the broadly conceived structure of Utopia. Like the predecessor, it consists of two parts, and there is a similar shift in emphasis within the two books. The first part emphasises its own dialogic nature (remember: Book I of Utopia also has a subtitle, where the generic label "discourse [sermo]" is used!). As a next step, it should be examined whether similar self-reflexive remarks could be identified in Nicholl's work, which might shed more light upon his peculiar generic hybrid.

First, it must be clarified that there is no explicit reference to either Thomas More or to Utopia in the text. However, Part I contains at least one section where the purpose of conversation is a central subject:

\footnotetext{
122 As Shrank puts it, the work "plays with the boundaries of fact and fiction (...) by extending the presence of the (fictional) interlocutors into the dedicatory epistles".
} 
$L$ I pray you good father holde me not for importunate, to demaund of you a question or two.

$P$. Rather Madam you seeme so wise, that I receyue pleasure by your communication: therfore good Madam say on.

L. I will not require of you to signifye vnto me the lawes, customes, rites, ceremonies, and strainge vsages of the Hethites, among whom you haue trauailed, for I know the same to be horryble and abhominable. But tell me I pray you, haue you bin among the Christians in East India. (I/A4r)

This place reminds one of the scene where Raphael is introduced to Morus in Utopia, and Morus thanks Giles for "taking such pains that I might have a talk with one whose conversation he hoped would give me pleasure" (CW 4, 15). "Conversation" or "communication" is described as a source of pleasure in both works, and when in Part I, Listra bids farewell to the Pilgrim, she refers to their dialogue as "godly conuersation" (I/B8v). With a certain amount of self-restraint, I do not attribute any special importance to the use of the word "signfiye" here, and deem that it is used in the obsolete sense of "notify or inform" (OED). The emphasis on conversation, as a sign of the awareness of the genre is significant, nonetheless, as is the restrictive adjective "godly".

Following this thread, another aspect of formal-structural similarity can be identified, still within Part I. In Book I of Utopia, Raphael regularly uses examples as part of his argument. In fact, these examples gradually move the reader away from the realistic setting of the conversation toward the description of the fictitious land that is the subject of Book II. In this sense, the whole of Book II can be viewed as an extended example for the case (communal property) established before. A Pleasant Dialogue also contains an interesting example, but with possibly different purposes. The text, provided in Appendix 2., is an embedded exemplum, in a part of the book where Listra's governing question is: "Then how dooth the poore folke obtaine Justice against the riche and mightye" (I/B1r). The answer provides rich details about how the "most famous 
learned man within the precynct of the whole Cittie" is appointed as the advocate of the poor, defending them for a decent wage from the citizens (I/B1v). The 'Attorney of the Poor' presents the case, and then all the judges put aside every other case and dispatch the poor man's cause immediately (Ibid.). The detailed account of this institution is followed by a negative example, the tale of the Butcher and the Apothecary, a didactic, fable-like example about the ills of corruption. Here, the purpose of the embedded text is clearly stated by the author: "Madam I tell you this merry tale, to the ende that you may know how in this happy Lande, it preuaileth not for the ritch to say I haue a fat purse" (I/B2v). The fable is complemented with a moral, but then a longer exposition follows which makes much more of the story:

And certainely the godly Diuines, are a great cause thereof, for they will not let to tell all estates their faultes, by some honest meanes: by reason whereof, they doo well know, that they themselues, shall come to iudgement, and be Iudged, so that according to the oppinion of S. Ierom, they haue dayly the sounde of the Trumpet in their eares, that shall call to Iudgement. And this is the principall cause, that they do liue in the feare of God, and are blessed. (I/B2v-r)

For a few moments, the text seems to adopt the style of a sermon based around an exemplum, and if legal equality is proposed, it is proposed because of serious devotional considerations. The importance of preaching witnessed here is more explicitly expressed in the part where the clergy of Crangalor is described, whose main function is to be the "Criers of God," whose mission is "to proclayme, preache and set foorth the lawes of the euerlasting God, as well in teaching, as in our liuing \& behaueour" (A5r). In connection with polemical dialogues, Zlatar $(2011,19)$ stresses the connection with "more 'popular', generally non-agonist genres, such as the sermon and the catechism". Here, that connection is two-fold: sermon-like techniques are used, but 
at the same time, the importance of the genre is explicitly declared. And this declaration, in my opinion, is clearly driven by religious instead of literary motivations.

At least one place from Part II should be cited for similar reasons, and because of the interesting literary device used there. In the city of Pembay, a certain Raphael, "a man of good and godlie conuersation" accompanies the pilgrim. The guide tells him that in the "Iesus Colledge," there is once a week "some virtuous Commedy represented" (B3r-v). What follows is the description of a didactic tragedy in scarcely a page, only to be followed by a part where a young man appears "to make playne the meaning therof" (B4r). The embedded drama is a didactic-allegorical (and rather morbid) story of 24 singing and dancing children who are struck by Death with an arrow one by one. If we called the tragedy didactic then its explication comes close to pedantry, concluding with the following advice: "if the Sherife Death, come not for us the Sundaye, than looke for him the Mundaye: if not then, his coming shall be some other daye of the seuen" (B5r). In her usual reduced role in Part II, Listra briefly rejoices for the "a blessed exercise" (Ibid.). This episode, in my opinion, tells a lot about the text's Reformist stance, but it is even more important for our purposes because it shows us, for the second time, an ideal way of reading. Already the commentary on the tale of the Butcher and the Poticary was somewhat overspun: the story obviously has a certain moral regarding the human condition, but the kind of interpretation suggested by the narrator, which appeals to the final judgment while at the same time completely neglects the satirical element, is teleological at best. In this later episode, a separate character is introduced, who tells us how to read the allegorical play, but the interpretation is in fact, longer than the play itself, once again bringing the scene closer to the world of sermons.

Scores of other places could be cited where More's influence can be traced. Both works are concerned with capital punishment (but Nicholls is stricter: he only allows 
repentance for sinners), a central concern is the legal representation of the poor in Nicholls. In both works, the narration takes place outside England, but the narrator has some sort of experience with England, which offers a unique external perspective in both cases. That religion is a central concern in A Pleasant Dialogue, has, I presume, already become clear, but it should also be noted that tolerance and the mutual living of people of different religions, which is the single most important aspect of the section on religion in Utopia, is a central concern throughout Part II. ${ }^{123}$ We come near actual textual reminiscence in the part about "contemplatives," a strange sort of religious order quite similar to the two sects described in More.

The list of similarities could be and at a next stage of this project, will be significantly expanded and discussed in more details. Yet, even at this point of research, I am convinced that the main lines of analogies have been explored, along with some important deviations. As a tentative conclusion, it has become obvious that Utopia served as a model for A Pleasant Dialogue. At the same time, this similarity surpasses simple overlaps in the subjects covered in the two texts. The overall structure of the work is rather close to the original pattern: the dual structure of Utopia is followed in Nicholl's work, and therefore, I cannot agree with Deitch, who suggests that "Elizabethan utopia-dialogues were (...) popular enough to warrant continuations (Deitch 1999, 54)." In my opinion, A Pleasant Dialogue shows a high level of awareness of its predecessor. This is most palpable in the way the text is organised, and

\footnotetext{
${ }^{123}$ Let me give two brief examples here: "[Peter] was an excellent learned Phisition, hee I say, instructed me of all the orders of that Cittie, for they are most Christians: except a fewe Iewes, which haue theyr Synagogue and dwelling by themselues" (II/B6v). Later, in Pembay, we learn about extremely strict laws, to give one example: "they abhorre great and sumptuous feastes, and Bancquettes: for they holde opinion how, that at euery great Bancqet, the Diuell Himself is a present guest" (II/B5v).
} 
in the way the paratexts are employed in it. Just like in Utopia, they participate in the fictional grounding of the work, but in a sense, that use is further enhanced and combined with the dialogue form on a higher level: by exchanging the narrators of the two parts, what we eventually receive is a dialogue between Part I (narrated by Listra) and Part II (narrated by the Pilgrim).

At the same time, the episodes discussed above reflect a significant impact of the polemical culture of the time. Although Zlatar $(2011,9)$ dismisses A Pleasant Dialogue because of its affiliation with "works targeting commonwealth issues". Despite all the ways Nicholls makes use of Utopia and its emerging genre, despite all the innovative solutions in terms of form and structure, the work is fashioned according to completely different principles. The distance is increased not only by the split between humanist ("genre") and Tudor ("anti-genre") dialogues, but by the different underlying program, too. Shrank (2007) is no doubt right in claiming that "the bent of the work is unmistakably reformist”. Incorporating typical Protestant didactic genres (fable, school drama), and emphasising the role of the sermon (also making use of its techniques), the work suffers under the burden of the fervent desire to teach, and although the title page of Part II promises a "delectable and profitable" reading, the text is obviously anxious of its own fictitious nature. Just like the fable embedded, it was not intended to be read (only) for its "merriness," but through "godly conversation" and a collection of examples, wants to move the reader to godly life. It is clear that we witness here an Erasmian method of putting "pleasure in the service of edification", and this aspect of 
the text will become even more significant if we take a quick look at two similar dialogues. $^{124}$

\subsection{Summary: a possible approach to A Pleasant Dialogue}

In this section, I would like to propose a different approach to A Pleasant Dialogue, an approach based on an article by Warner, who starts from the assumption that "more classical" dialogues are simply missing from English literature, and if we read what we have with the classical models (including More!) in mind, we are doomed to disappoint ourselves. According to him, the proper approach to such texts is if we treat them as "dialogue clusters" (Warner 2004, 66). Already the numbers seem to justify him: if we take a look at the chart above, it is clear that dialogues tend to appear in waves. One of his examples is in fact, such a wave: the series of dialogues from the time of Henry VIII's divorce, where the newer and newer dialogues aptly reflect the growing tension on the level of rhetoric. In my opinion, a similar cluster-based reading would be fruitful in the case of the utopian dialogues published between 1579 and 1583 . Here, however, I can only offer a few hints at the possible areas of such an inquiry.

The first obvious similarity between the works is their dual structure. A Pleasant Dialogue, Siquila. Too Good to Be True, and The Anatomie of Abuses each consist of two parts. Based on my observations, I am not convinced that this is only the result of the commercial success. At least in the case of A Pleasant Dialogue, there is a structural unity that overarches the two books, and in my opinion, the second part was conceived together with the first one (of course, we are getting dangerously close to the

\footnotetext{
${ }^{124}$ As Zlatar $(2011,15)$ puts it, "Erasmus De utilitate colloquiorum is a defence of pleasure in the service of edification, and this instructive pleasure is specifically linked to the fictional dimension of the colloquy." She finds Erasmus Colloquia an important influence on the fictional aspect of polemical dialogues. Cf. Zlatar (2011, 10-6, specifically on reception: 11).
} 
problematic inception of Utopia). Even if no such unity could be identified in the other two works, it is an interesting question why such an upsurge in the number of utopian dialogues shows in four years. Is it simply a sudden wave of success that is cleverly harnessed by the authors? Or is there something between 1579 and 1583 that makes audiences more receptive of utopian texts? These are questions waiting to be answered.

On the other hand, it is an interesting aspect of these texts that they all balance on the verge of fiction/non-fiction. As if initially they found fiction a convenient tool, but later they grew a suspicion against their own vehicle. This was discussed in more detail in Nicholls's work, but let me cite here another example. Nicholls does not follow More in the subject of names, and instead, uses simple Biblical names for the guides helping the pilgrim: Mighell, Raphael, Peter, Ioseph. This is not the case, however, in Siquila. Too good to be true... which bears the closest resemblances with More's text in this respect. The narrator is Siquila, who travels to Mauqsun, where he talks with Omen. All these names can be read in reverse direction, and not much invention is needed from the reader to notice this. However, Lupton is (too) eager to get it right:

\footnotetext{
(...) it is harder for the reporter thereof to tel a lye, than for a common lyar to tell a true tale, which must needs be granted, if his name called Omen, and the name of his Countrey called Mauqsun (...) be aduisedly marked and considered, especially é couerso construed. (Lupton 1580, A2r)
}

The remark is interesting on one hand because its first half is quite similar to the famous passage in More's letter to Giles in Utopia: "For as I shall take good heed that there be in my book nothing false, so if there be anything in doubt I will rather tell a lie then make a lie, because I had rather be good than wise" (CW 4, 41). On the other hand, while the place and character names are crafted in a way similar to the application of names in Utopia, the playfulness is completely destroyed by the author, as he too often 
highlights that the story of this unknown land is "too good to be true". This phrase becomes the running title of the volume, and thus Lupton uses the paratextual space not in order to blur the line between fact and fiction but on the contrary, to make it clear.

Stubbes text, The Anatomy of Abuses (1583) is probably the best known from the three for its violently anti-theatrical tone. This book, similar to the other two, was written in dialogue form, and this was, again, propagated on its title page. The form and structure, and the utopian debt of the text is somewhat overshadowed in criticism by its fervent anti-theatrical stance, however, if we juxtapose it to the other two dialogues, other weightpoints seem to emerge. Just like Utopia, it is surrounded by prefatory letters and commendatory verses, and some of these are in Latin. Stubbes work even features a verse dialogue between the author and the book, which we only saw in A Pleasant Dialogue before. At the same time, there is an important difference in the work: the imaginary land is anything but ideal, so in fact what we see in Stubbes is the birth of the first anti-utopia. Fiction is used here, once again, as a means to produce examples, but this time they are negative, cautionary ones.

With so many parallels, the question remains: how these three texts came together at the turn of the 1570 s and 1580 s? ${ }^{125}$ In my opinion, part of the answer lies in the development of the Puritan tradition, and the way the movement made use of literature. The texts obviously form a cluster, and discuss the ills of society from a Puritan perspective, occasionally with direct textual adaptations. ${ }^{126}$ All of them transmit harsh social criticism, which at times includes the criticism of entertainments not far

\footnotetext{
${ }^{125}$ I will have some more specific suggestions in the next chapter, where, in connection with a later text, we will see that many of the issues raised by these utopian dialogues return.

${ }^{126}$ Lupton seems to use a significant passage of A Pleasant Dialogue, where a charivari is described. See Lupton (1580, 47-50).
} 
from literature, and probably this, together with the mentioned general distrust against imaginative literature is the source of their partly pragmatic, partly ambiguous and unconvincing use of fiction. They clearly engage in the same debates as the so-called polemical dialogues, and their use of fiction is similar, too. Like the polemical dialogues, they too use fiction only as "a means to render religious discourse more palatable to their target readership: the unlearned" (Zlatar 2011, 28). Probably the exoticism represented by an imaginary displaced land was also useful for this reason, but it was probably an effective weapon against the censor, too. ${ }^{127}$

Taking a simultaneous look at these authors is revealing from other aspects, too, especially if we suppose that they addressed an unlearned readership. While in Thomas More's figure, we discussed one of the prodigals of not only sixteenth-century English literature, but of literature as such, these three figures are obviously of a different cast. Neither of them received full university education, and to some extent, all of them could be called a "semi-professional author," ranking among the "hack writers of the capital". ${ }^{128}$ The ship-owner and translator Nicholls, the political and religious pamphleteer Lupton, and the pamphleteer Stubbes all belong to the same social strata, and they are member of the same milieu as the translator of Utopia, described in the following way by Cave:

(...) in London in the reign of Edward VI, Utopia was being actively read and discussed by people of modest means and education who then had the idea of disseminating it more widely for people like themselves whose Latin was not up to the task of reading the original (Cave 2008, 89).

\footnotetext{
${ }^{127}$ Zlatar $(2011,28)$ identifies these two goals in the use of fiction by dialogists: facilitating edification, and defence against censorship, or "licence to boldness".

${ }^{128}$ Stubbes is described with these words in the ODNB, cf. Walsham (2004).
} 
Of course, Robinson was still a relatively well-educated figure, with solid knowledge of Latin. Yet, the readership he expected was obviously different. The three dialogues represent a further step in the popularisation of the form. In this sense, it in by no means incidental that they connected the form with one of the most popular genres of the time, the dialogue, which was so popular precisely because of its elementary nature, because it "played a key role in the schoolroom" (Zlatar 2011, 11). From this perspective, it will be even more stimulating to turn our attention now to a figure who, although could not compete with the fame and glory surrounding More, at least in his sound education, his prominent, controversy-ridden career, and his literary merits, was an equal of the arch-utopist of England. 


\section{Converging traditions. J. Hall's Mundus alter et idem (1605) and J. Haley's Discovery of a New World (1609)}

In the introduction, John Milton was quoted twice, once for rejecting utopianism as an infertile political position in 1644 in Areopagitica, then for praising utopia in an earlier 1642 polemical writing as a type of literature brought to perfection by Thomas More and Francis Bacon. ${ }^{129}$ It is vital to re-quote this earlier passage here at some length not only because it is concerned with the author to be discussed here, Joseph Hall (15741656), but also because of the poetical-literary reflections it includes:

Could he not beware (...) that no sooner would that word mime be set eye on in the paper, but it would bring to mind that wretched pilgrimage over Minshew's dictionary called "Mundus alter et idem," the idlest and paltriest mime that ever mounted upon bank? Let him ask "the author of those toothless satires," who was the maker, or rather the anticreator of that universal foolery, who he was, who (...) could say no other but contrary to the divine mouth, that it was all very foolish. That grave and noble invention, which the greatest and sublimest wits in sundry ages, Plato in Critias, and our two famous countrymen, the one in his "Utopia," the other in his "New Atlantis," chose, I may not say as a field, but as a mighty continent, wherein to display the largeness of their spirits, by teaching this our world better and exacter things than were yet known or used: this petty prevaricator of America, the zany of Columbus, (...) having rambled over the huge topography of his own vain thoughts, no marvel if he brought us home nothing but a mere tankard drollery, a venereous parjetory for stews. Certainly, he that could endure with a sober pen, to sit and devise laws for

${ }^{129}$ See Chapter 1.2 above. 
drunkards to carouse by, I doubt me whether the very soberness of such a one, like an unliquored Silenus, were not stark drunk. ${ }^{130}$

Now, it must be posited that this is, of course, Milton at its worst. As a recent biographer claims about this very tract, the left hand of the poet operates here (as elsewhere) with "insults, sarcasm and personal attacks". ${ }^{131}$ The eloquent praise of the genre and its two great English representatives serves the wider rhetorical purpose of defaming (or rather demolishing) the opponent, Hall. Yet, even if the opinion is heavily prejudiced, the literary terms involved are interesting. As late as 1642, utopia as a genre must be circumscribed ("that grave and noble invention"), whereas Hall's utopian/dystopian text comes into play via an association with the generic label 'mime'. This is all the more interesting because the party suffering under Milton's heavy blows, Hall is among the first registered to use the adjective 'utopical', clearly in the more general sense of something impractible. ${ }^{132}$ The two opponents are linked in their use of terms.

It is obvious that Milton exploits the above generic classification in a relentlessly teleological way, but other contemporaries were less biased against Hall. The German translation was promoted on its title page as "Utopia pars II", whereas only one year after Milton's fervent attack, Hall's work was republished in a most prominent company: together with Bacon's New Atlantis and Campanella's Civitas Solis. ${ }^{133}$ For

\footnotetext{
${ }^{130}$ It seemed necessarily to make significant omissions here, as Milton spares no words when defiling his opponent. A version of the passage without omissions and with more context is included in Appendix 3.

${ }^{131}$ See Forsyth $(2008,76)$.

${ }^{132}$ On Hall's uses of the word, see Wands (1981a, 86).

${ }^{133}$ Mention of the German translation: Wands $(1980,1)$; of the 1643 edition: McCabe $(1982,92)$. See Winter $(1978,44)$ for a $17^{\text {th }}$ century German adaptation of the text („Erklärung der Wunder-seltsamen Lanc-Charten Utopiae, so da ist das neu-entdeckte Schlarraffenland...”, published around 1650 in Nürnberg and other German cities).
} 
contemporaries, then, the work was obviously associated with the genre, even if, as it will be demonstrated, modern critical works sometimes seem reluctant to admit the generic kinship between these works.

In the scope of the present project, Hall's work is certainly the ideal next step. After looking at a heavily discussed work, which was written in Latin by a humanist acclaimed throughout Europe, we moved on to more or less obscure English works by more or less obscure English authors with humbler origins and achievements. Hall is somewhere between these extremes. On one hand, he wrote both in English and in Latin, and although he wrote the work under scrutiny here in Latin, its English version came out just a few years after the original. This bilingualism already connects the text to the two preceding chapters, but as I will hope to prove, there are many other features which suggest that Hall is not only aware of More, but also of the English works discussed here. As a historical figure and an author, he was a good deal more influential than the utopia writers of the 1570s-1580s (as the debate with Milton might already suggest), and the popularity of his devotional works in Germany is on par with More's impact. ${ }^{134}$ His position in critical literature is again between the two extremes: unlike in the case of the Elizabethan dialogists, there are a handful of articles and a few monographs on Hall's literary achievements, a modern translation of his utopian work is available, and, if often with reservations, the work usually elicits at least some mention in utopian monographs.

\footnotetext{
134 The immense popularity of Hall's work is summed up by Sträter (1987, 83): "Der Zahl seiner deutschsprachigen Auflagen nach ist Joseph Halls Trakt über die Kunst der Meditation „The Arte of Divine Meditation" (1606) eines der erfolgreichsten englischen Bücher auf dem deutschen Buchmarkt gewesen." In fact, Hall was probably the most widely read English author in Germany, more than thirty of his works have been translated, and in Damrau's evaluation "[f]or the development of Pietism, the German reception of his meditations are particularly important." Cf. Damrau (2006, 71-2).
} 
Besides this middle position, the work is also usefully applicable for the specific focus of my dissertation. In what follows, I provide a brief textual and critical overview about the text. This will be followed by an inquiry into the use of the dialogue form, and the paratextual structure of the work. Both aspects are highly relevant in the case of Mundus: while the dialogue form is still clearly haunting there, it plays a significantly reduced role, whereas in terms of paratextual complexity, no other text comes as close to Utopia as Hall's. These coupled with the interesting self-reflexive literary remarks in the text, and a new, apparently more conscious approach to utopian fiction, Hall's work and its contemporary translation promise to shed new light on many of the questions so far discussed.

\subsection{Mundus and Discovery - Textual and Critical Introduction}

Mundus alter et idem sive Terra Australis ante hac semper incognita longis itineribus peregrini academici nuperrime lustrata auth: Mercurio Britannico Mundus was, according to its title page published in "Francofourti apud haeredes Ascanii de Rinialme", with no year given. ${ }^{135}$ Thus, the title page conveys a fictional author, a fictional place of publication, and no year, in sharp contrast to the real, though unknown geographical location to be described: Terra Australis Incognita, which was actually present on contemporary maps. As a result of John Millar Wands's strenuous efforts, both the time and place of the publication have been clarified, and consensus in the question of authorship has been reached. The book was published not in Frankfurt, but

\footnotetext{
${ }^{135}$ I consulted the original text through the copy available in Early English Books Online, STC $2^{\text {nd }}$ ed, 12685. In order to avoid confusion among the versions, I refer to that edition as "Mundus 1605". Wands's English translation is referred to as "Another World 1981", while the contemporary translation of John Healey is referred to as "Discovery 1609" and "Discovery 1613", depending on whether the first or the second edition is referred to.
} 
in London in 1605, although it was indeed listed in the catalogue of the 1606 book feast in Frankfurt. ${ }^{136}$ As for the authorship, Milton's above-quoted passage is in fact the first reference to Joseph Hall as the author of the text, and Wands (1981b, xiv-xv) convincingly shows that the other "suspect," Alberico Gentili was only an accomplice to Hall. ${ }^{137}$ These pieces of information already prompt a few questions. We have already seen utopian works with the author only hinted at: A Pleasant Dialogue from the previous chapter contained only the initials of the author. The title page to the first part of Lupton's Siquila contains no author, but the dedication is signed by the author, and he provides his full name. Mundus seems to be the first utopian endeavour where the author is also fictionalised.

Of course, there were a number of reasons for Hall to create a fictitious author for his work. The satirical tone, and its (at least to a Puritan taste) moderate religious stance, counterbalanced with unbridled anti-Catholic diatribes might have indeed been inappropriate for the author who "had long ago said good-bye to the Muses (of whom he was a noted supporter) and had devoted himself to the sacred calling of Theology" (Another World 1981b, 4). The question is further complicated, however, by a curious ecclesiastical order from 1599, which directly relates to Hall. Generally referred in critical literature as the "Bishop's Ban", it seems that the order primarily attempted to suppress satirical literature, although it also covered epigrams and in a few cases, not genres, but specific authors were named. On this document, Hall is mentioned in the following context: "Satyres tearmed HALLes Satyres viz. virgidemiarum or his tootheles or bitinge Satyres," and refers to Hall's collection of satiric poems, the

\footnotetext{
136 The rather complicated publishing history is summarised in Wands (1980).

${ }^{137}$ On authorship, see Wands (1981b).
} 
Virgidemiarum. ${ }^{138}$ The order promulgated by the Archbishop of Canterbury and the Bishop of London has, through its vagueness, inspired different interpretations: while some see a moral-edificatory underlying purpose, others suspect that it was driven by the establishment's political motivations. ${ }^{139}$ Whatever the original intention was, Mundus might have been counted among the works which were deemed dangerous by the ban. Although in my opinion, a moral agenda is clearly at work in Hall's text, its satirical and grotesque tone effectively conceals this, and as Milton's cited ramblings demonstrate, this aspect of the work opens up wide surfaces for misreading, even if in Milton's case, it is a calculated misreading. Yet, another specimen of utopian literature exemplifies what the dedication suggests: that the work is not fitting for the name of an orthodox clergyman. There are interesting parallels in the life of Francis Godwin and Hall: both of them were engaged in literary-scholarly endeavours before the ecclesiastical career, and both became a bishop with time. And both of them published utopian texts under pseudonym. ${ }^{140}$

Whether its author was known or not, the book became an instant success: within ten years, it was published twice in Latin, a German translation came out, and it was also translated by John Healey into English in 1609 with the title The Discovery of a New World or a Description of the South Indies. Hitherto unknown. During the ensuing discussion, I will refer to both versions, therefore it must be made clear here that Healey's version is generally regarded as a loose rendering of Hall's original as Wands (1981b, 1v) puts it, it “might perhaps be more accurately called an adaptation".

\footnotetext{
138 Cited in Asworth-King (2009, 1), also available in Davenport's edition of the poetry of Hall (1949, 293-4). The latter includes another related entry from the Stationers' Register.

${ }^{139}$ See Asworth-King (2009, 2-4)

${ }^{140}$ For a recent biography, see Godwin (2009, 11-17).
} 
Hall's monographer, McCabe $(1982,1)$ opens his book with a lamentation about the small amount of critical literature available on Hall, which fails to reflect the author's popularity in his own times. Yet, even if we cannot disagree in terms of the amount, there are vastly different, thought-provoking evaluations of the work. The complexity of Mundus, with its myriad of allusions to classical and contemporary authors and works, is generally acknowledged in most critical assessments. One of its early admirers, Slayer, puts the text into the context of late Renaissance authors, and after complaining about the general neglect surrounding Hall's work, ventures as far as to claim that "judged merely as a clever piece of literary craftsmanship, the Mundus is superior to the Utopia" (Sayler 1927, 321-334). He identifies important differences between Utopia and Mundus, and through specific textual analogies suggests that the impact of Erasmus', but above all, Rabelais' works is even stronger, a point reiterated in Huntington Brown's book Rabelais in English Literature six years later (Sayler 1927, 327-32; Brown 1967 [1933], 103-5).

In the introduction to his translation, Wands sees in Hall's work one of the first dystopias in English literature, but he finds the connection between Mundus and Mennipean satire more vital (Wands 1981b, xxv-xli). In an article published in the same year, he offers a detailed analysis of the relationship between Hall's and More's work, and identifies several key areas of imitation. One is the language itself, as at the time of writing Mundus, Hall wrote almost exclusively in English. Initially, he hints at a tentative link between the language and the mentioned Bishop's Ban, but finds that only the pseudonym and the suppression of the place and time of printing are related to it, while it is "more reasonable to interpret the choice of language as Hall's consciousness 
of following a tradition established by More". ${ }^{141}$ Other areas of imitation are identified to which I will return later.

In a similar vein, McCabe reads Mundus in the context of the satiric revival of the late $1590 \mathrm{~s}$, but at the same time, emphasises the allegorical nature of the work, and identifies a consistent underlying moral agenda, which is also reflected by the topography of the work:

(...) we may say that Mundus is a Menippean satire upon the vices of Europe written in the guise of an allegorical travelogue recounting a fantastic journey to the great Southern Continent (McCabe 1982, 74).

Besides the above positions, Mundus is also read by some as a representative of the popular "Land of Cokaygne" tradition of imaginary lands with infinite abundance. In Davis's book, Hall's text is in effect excluded from the group of "proper" utopias precisely on this basis, an opinion many would find problematic (Davis 1981, 19-22). ${ }^{142}$ In a more recent article, Davis approaches Mundus from a different aspect, calling it "a satiric inversion of the claims of travel literature" (Davis 2008, 8). Similar perspective is employed in Mancall's book on the acclaimed Elizabethan travel writer, Richard Hakluyt, in which Mundus is seen as an "attack on the idea of travel," implicitly positioned against the travel accounts so popular at the time, a work that "cast colonies as dystopias to be avoided at all costs (Mancall 2007, 258)." Fausett's book is unique in that it touches almost only upon the question of Mundus's gender reversal, and connects Hall's work to Thomas Artus and Béroalde de Verville, who also showed interest

\footnotetext{
${ }^{141}$ See Wands (1981a, 90).

142 There are interesting treatments of the "Schlaraffenland" tradition, but also of Hall's text in German scholarship. For a general overview of the „literaturtranszendierenden Vorstellungskomplex”, see Roßbach (2006). Von Koppenfels (1981) focuses specifically on Mundus, and like Wands, emphasises its connection with Mennipean satire.
} 
towards gender issues and hermaphroditism. According to him, Hall was one of the initiators of the "austro-hermaphrodite theme," perfected later by Gabriel de Foigny, whose La Terre Australe connue (1676) is an important piece of hermaphroditic utopianism (Fausett 1993, 48-51). Considering that the hermaphrodite subject is only present in a very small portion of the book, this seems to be a rather selective evaluation of the work, even if appears that this aspect establishes a link with the Elizabethan dialogues. All in all, the best summary of Hall's attitude to literature is probably that of McCabe:

In the strict sense of the terms Hall was neither philosopher nor theologian, but an impassioned devotionalist deeply convinced of the moral efficacy of imaginative literature. Though aesthetically an irrepressible innovator, he remained to the end theologicallly orthodox and conversative. (McCabe 1982, 1).

As this short review of critical opinions hopefully revealed, Mundus is informed by multiple literary traditions: utopian writing, Mennipean satire, travel writing. As we will see, this formal multiplicity is unified by an overarching, progressive moral agenda against vices of all sorts. The form invented by More is filled here with content quite similar to those of the Elizabethan utopian dialogues. It is time to explore how such a unique combination influences the dialogic and paratextual aspect of the work.

\subsection{Dialogicity and Paratextuality in Mundus}

Mundus appeared about two decades after the dialogues discussed in the previous chapter. There the dialogue form was an obviously important aspect, promoted on the title page of each piece, most probably with the purpose of pushing the unfamiliar (the experimental genre of vernacular utopia) toward the familiar (the exceedingly popular dialogue genre). Since Mundus was written in Latin, there was obviously no such need 
in working; the originally intended readership was not identical with the consumers of vernacular polemical dialogues. The question for the present investigation, therefore, is to what extent can Hall's work be seen as a direct descendant of Utopia, and whether the author, known as an innovative writer with strong opinions on contemporary English literature, is influenced by the early English followers.

The aspect of paratextuality is exceptionally helpful here. Simply put, no other work I have seen is as complex in terms of paratexts as Utopia, and no other work seems to apply this technique with such awareness. Wands (1981a, 88-9) claims that besides its Latin language, the use of the paratextual material is the most visible area of imitation in Mundus, and in his opinion, it serves the same purpose as in Utopia: to lend authority to the text. A short glance at the list of paratexts gives a good idea about the richness of the parerga, and the information is particularly revealing in comparison with the English version of the text:

\begin{tabular}{|c|c|c|}
\hline Paratext nr. & Original (1605) & Healey's translation (1609) \\
\hline 1. & $\begin{array}{l}\text { Title page with engraving (Mercury), } \\
\text { author: "Mercurio Britannico" }\end{array}$ & $\begin{array}{l}\text { Title page with engraving } \\
\text { (Mercurio). Enhanced with simplified } \\
\text { maps containing the four countries } \\
\text { described in the books, author: } \\
\text { "English Mercury" }\end{array}$ \\
\hline 2. & $\begin{array}{l}\text { Dedication, a simple dedicatory phrase } \\
\text { of a few lines to Henry, Earl of } \\
\text { Huntingdon, signed by Mercurius, } \\
\text { offering "his world" }\end{array}$ & $\begin{array}{l}\text { Dedication, a full dedicatory letter to } \\
\text { William, Earle of Pembroke, signed by } \\
\text { "I. H." }\end{array}$ \\
\hline 3. & $\begin{array}{l}\text { Greetings to the reader, signed by } \\
\text { William Knight, with the running title } \\
\text { "Praefatio ad lectorem" }\end{array}$ & $\begin{array}{l}\text { N/A (1609 edition) } \\
\text { To the Reader (1613 edition), } \\
\text { "Instructions for their voyage into this } \\
\text { new world," signed by the translator, } \\
\text { Iohn Haley }{ }^{143}\end{array}$ \\
\hline 4. & $\begin{array}{l}\text { Table of Contents, } 3 \text { pages, } \\
\text { excessively detailed }\end{array}$ & $\begin{array}{l}\text { Table of Contents, } 6 \text { pages, } \\
\text { excessively detailed }\end{array}$ \\
\hline
\end{tabular}

${ }^{143}$ This was inserted in the second edition of Healey's work. ESTC adds the note for this later version that "This state has original [par].4 cancelled by ${ }^{2}[\text { par. }]^{4}$ containing a new preface." Cf. STC $2^{\text {nd }}$ ed. 12686/ESTC S92843 (http://estc.bl.uk/S92843). 


\begin{tabular}{|c|c|c|}
\hline 5. & $\begin{array}{l}\text { The Occasion of this Travel and the } \\
\text { Introduction, a prefatory section of } 19 \\
\text { pages, recounting a discussion between } \\
\text { three characters (Mercurius, Petrus } \\
\text { Beroaldus Gallus, and Adrianus } \\
\text { Cornelius Gallus). The original title, the } \\
\text { running title and text itself also } \\
\text { contains Greek words/passages. }\end{array}$ & $\begin{array}{l}\text { The Occasion of this Travel and the } \\
\text { pre-instruction for it, translation of } \\
\text { the original. No Greek in the title and } \\
\text { the running title, but left in the text. }\end{array}$ \\
\hline 6. & $\begin{array}{l}\text { Map of the whole world, fold-out, } \\
\text { with the southern continent as large as } \\
\text { the rest of the world }\end{array}$ & N/A ${ }^{144}$ \\
\hline \multirow[t]{2}{*}{7.} & $\begin{array}{l}\text { Four maps, of the different regions } \\
\text { described in the different chapters of } \\
\text { the book, at the beginning of the } \\
\text { relevant chapters }\end{array}$ & N/A \\
\hline & Main Text & Main Text \\
\hline 8. & Marginal notes & Marginal notes \\
\hline 9. & $\begin{array}{l}\text { Different embedded engravings: } \\
\text { figures and inscriptions }\end{array}$ & $\begin{array}{l}\text { Different embedded engravings: } \\
\text { figures and inscriptions }\end{array}$ \\
\hline 10. & $\begin{array}{l}\text { Index of Proper Names, } 9 \text { pages, } \\
\text { providing the etymology of the place } \\
\text { names in the book }\end{array}$ & N/A \\
\hline
\end{tabular}

4. Table Paratexts in the Latin Mundus and the English Discovery

We should immediately notice that the primary tendency of the English version is the reduction of the original richness: there are no maps, and the index of proper names is also missing. There is only one complete replacement within the paratexts: while the Latin offers an address to the reader by William Knight, the publisher of the work, the translation substitutes this with a similar address by the translator, John Healey. ${ }^{145}$ In what follows, I would like to highlight a few important aspects of the

\footnotetext{
${ }^{144}$ The two copies (one of the earlier, one of the later edition) I could access through EEBO contain no maps. The relevant ESTC entries do not mention the presence of maps, so most probably they were omitted in the English rendering of the work.

${ }^{145}$ Interestingly, this is only available in the second edition of the work. However, the copy of the Discovery (1613) available in EEBO contains a hand-written note "One leaf of preliminary letter captioned 'I. H. ... unto I. H.' is lacking," and also claims that it was torn out, probably on purpose, from the Huntington Library's copies, too. Nonetheless, Wands (1981b, xv) takes it for granted that "[t]he first edition of The Discovery contains the translator's preface headed "I. H. the Translator, unto I. H. the Author", Huntington Brown's modern edition of Discovery also contains it. As an address by the
} 
paratexts by focusing on the original version, and afterwards I take a brief look at some of the changes the English version introduces.

The most important aspect of the first paratext, the title page, as noted above, is the use of a fictitious author, Mercury, but also the depiction of that author with an engraving. The second item is the succinct dedication, which, however, contains an important part: Mercury offers not a work, but "his world". Although this might seem but a minor difference, it is significant for the representation of a literary work as an independent world, and even though Milton was, as we saw, fervently inimical to Hall, their concept of utopian literature is almost the same. While Milton calls utopia a "mighty continent" where authors can "display the largenesse of their spirits", Mercurius-Hall refers to his own work as "his world". The literary potential of the form is clearly recognised by Hall, and this identification will be, as we will later see, determining not only for Mundus and Discovery, but also for many later authors. And as we will see, it is also a prominent, consistently followed thread in the preliminaries at hand.

The third paratext, William Knight's preface carries on the association between geography and literature:

Contrary to expectation, dear Reader, driven neither by storms nor by the never-ending tossing of waves, without winds, without sails, you have been driven to a new world. (Another World, 3)

In what follows Knight further develops the concept of »literature as a new world«, and suggests that the reader finds here the "living ideal of the world" (Another 
World, 4). The latter part of his dedication is about the author, and how he has now rejected such works of his youth. This is followed by a rather conventional excuse by Knight: although the author did not mean to publish the work, he could not conceal it from the world any more. Or, to be more precise, from "the world of the learned" (Ibid.), which is obviously interesting in the light of a vernacular translation quickly following the original. The whole argument is quite similar to the "found/received manuscript" narrative that is frequently used in later utopias, and the rhetoric is rather elevated here. Knight did not want to betray his friend, but was eventually so "overcome and enraptured by the beauty of the work" that he could not stand giving out the text from his hands. The argument is intertwined with the topical "sweet and delectable," and "profit and enjoyment" features attributed to the text. Whereas those attributions are quite conventional (we encounter similar arguments in both More and the later dialogues), the Knight hesitation about the publication and the final convincing argument of 'beauty', but even more the idea that the book opens up a new, previously unknown world for the reader signals a new direction in the self-perception of utopian literature.

The fourth paratext is the table of contents, which is something new, at least in the world of utopias. The division of the chapters, and thus, the overarching structure of the whole work is determined by the geography of the described lands, which is a typographical solution serving two different purposes. On one hand, the affinity between the work and contemporary travel books is reinforced. Richard Hakluyt's prominent Principal Navigations appeared only a couple of years before Mundus, between 1598 and 1600, and the immense volumes are lent particular authenticity through the elaborate typography. The table of contents are already overwhelming in this respect, serving not simply as a guide for navigating within the book, but obviously 
offering and early, impressive overview of all the "navigations, voiages, traffiques, and discoueries of the English Nation", a purpose strengthened by the caption above the list of contents: "A Catalogue of the Voyages", somewhat blurring the line between the voyages and their textual representations. ${ }^{146}$ Similar purpose can be traced in Hall's case, even if it calls this section conventionally "Index". At the same time, the division of the subchapters is organised around the following and similar subjects: general description, cities/people, wars, laws, religion. Even a short glance reminds us to More's division of the second book of Utopia. Of course, both show a strong influence of travel literature, and Hall's reflection of that influence is apparently stronger, while his chapters are more systematic and balanced. Yet, there is another possible motivation for such a division: the mentioned analogy between literature and geography. Reading a book - the dedication, Knight's letter, and now, the table of contents also suggests - is like exploring a new world.

The fifth paratext (The Occasion of this Travel and the Introduction) is a crucial one for several reasons. First of all, in the vein of the previous elements, it again refers to the whole work as a "travel", not as a book, carrying on the extended metaphor which was present from the title page till now. However, the ensuing discussion itself is interesting for different reasons: this relatively small section (in the original, 18 pages out of a total of more than 200 hundred) is the only part of the whole book which resembles (both in form and content) Book I of Utopia. While the dominant part of the work offers descriptions written (as the mentioned subchapters already suggest) very much in the vein of Book II of More, this separate section (it is not listed in the

${ }^{146}$ See Hakluyt (1598-1600, vol. 1.), title page and the Catalogue... 
"Index"!) is a discussion among three scholars. The basic setting is quite similar to the initial discussion between More, Giles and Raphael, so it should be explored how much similarity can be identified in the discussion itself.

The narrator of the whole section (and the whole book) is Mercurius, and the subject of the Introduction is clearly specified in the first few lines, where we read the following:

Of all the many conversations I had with Peter Beroaldus, a Frenchman, and Adrian Cornelius Drogius, a Dutchman, the one concerning the usefulness of travel stands out (in which, during our not unpleasant comparison of laws, customs, languages, and cities, a certain friendly dispute arose). (Another World 1981b, 9)

Obviously, we are in the same world of humanistic friendly conversation as in Utopia, and if More's work could be read as a model dialogue with a thesis to probe, a thesis is not hard to pinpoint here either: in Beroaldus' opinion, travel is useless, and can be perfectly substituted with books. This position is maintained until the middle of the conversation, when despite his scorn for small-scale travel, Beroaldus comes forth with a sudden suggestion for a grandiose endeavour. The basic idea is founded on a logical inconsistency noticed by Beroaldus in the term "Terra Australis Incognita" which indeed appeared in maps and atlases of the time: "For if they know it to be a continent, and a southern one, how can they call it unknown?" (Another World, 12). For our purposes, however, the preceding parts, when Beroaldus leads in his ideas, is much more important. First he hesitates to reveal his secret idea, but then adds the following explanation:

Truly, you interpret my silence badly, Drogius (...). Because great undertakings never proceed without a great apparatus and a long preamble of ambiguous terms, I seem to have thrust before you naked, all of a sudden, 
and without any warning, a plan of the greatest length - the offspring of one year. Indeed, the very plan I now communicate to you I had previously wanted to explain to you from its inception, gradually, not without some appropriate preparation of your minds, without which even those new designs that are most prudent may appear unpleasant and foolish. Now, truly, I see it is necessary for me to rush headlong into an inopportune speech about the whole matter (lest you suspect my friendship). (...) Only imagine that a long introduction, which I had in mind, had come first in regular order, so that you miss nothing from my complicated plan. (Another World, 12, my italics)

This passage is simply revolutionary for the present project in terms of the paratextual aspect. Although the Elizabethan dialogues evidently tried to provide an apparatus similar to that of Utopia, Hall's work gets much closer to the complexity of its pattern. Yet, that would still be plain similarity (even if of a greater extent), but in these remarks, we proceed one huge step further. In the chapter on More, I have cited a number of modern critical opinions on the structure of Utopia. However, probably any critical survey about the use of paratexts should start with Hall-Beroaldus' above remark, which could be seen as a structural overview of Utopia - and naturally, of Mundus as well. Such works are split into two: the "introduction" and the "design" or "plan" itself. This obviously refers to the two-book structure of Utopia, and then the identification between this Occasion and More's Book I becomes even more solid. Furthermore, just like in Utopia, the word 'sermo' is used here to refer to what follows. On the other hand, this passage fits well into the system of paratexts in Mundus. Previously, literature was depicted as a journey, then we read the above passage in the "introduction" to that journey, and that introduction warns us that similar designs should be preceded by a longer "introduction". On the other hand, such introductions or preambles often contain "ambiguous terms", which can again be read as a remark on the prefatory material of Utopia (where the basic ambivalence of reinforcing and 
undermining the fictional framework was simultaneously observed), but it is also profoundly characteristic to the Occasion. This introduction begins with Beroaldus' arguments against travel, whereas in the second half of the text, he tries to convince the other two interlocutors that the three of them should undertake the journey to Terra Australis Incognita. The conclusion to the introduction maintains this ambiguity. After reminding themselves of the hope Columbus' fortune represents, they eventually board a ship named Phantasia (rendered by Healey as 'Fancie'). ${ }^{147}$ Although this might appear as a simple word-play very much in the vein of More, we should probably attribute some significance to its occurrence here for other reasons. The book is like a journey, and the reader performs this journey on board his/her fantasy or fancy or imagination. Although the overarching allegory of reading as a journey weakens this sense a little bit, the work clearly appeals to the imagination of the reader. While this is interesting in itself, as we will see in the final chapter, such terms and such appeals become somewhat of a topos in subsequent English utopias of the century. Besides, probably this is the first time that an utopian work more or less openly talks about its own fictitious nature. More sought the equilibrium where the precise nature of the work is almost impossible to decide, and inevitably found it (as the example of Vasco de Quiroga and the misreader invoked in the preface to the epigrams show). ${ }^{148}$ The early dialogic imitators either tried to downplay it (like in the didactic explanations attached to the more 'fancyful' parts in A Pleasant Dialogue), or were anxious to call attention to it, even to excuse themselves for it (like Lupton, already in his title, Too good to be

\footnotetext{
${ }^{147}$ On the so-called Columbus topos, see Appelbaum (2002, 24-35).

${ }^{148}$ Vasco de Quiroga is often mentioned in the literature on Utopia. He is (in)famous for trying to apply the model described in Book II of Utopia in real life in the 1530s, when he made an attempt at organising the pueblos in México into communities based on the arrangement of Utopia. See for example Holstun $(1987,1-7)$ or Chordas $(2010,21)$.
} 
true). This is probably the first time when the fictitious nature of utopia is more readily accepted, and even if still within the framework of a wider allegory, openly theorised.

The sixth paratextual element is the group of maps bound in the book. These maps are obviously of a different cast than the map of Utopia. There, only a map of the island was available, and as many interpretations suggest, the map was far from realistic. ${ }^{149}$ These maps are, on the other hand, quite close to actual world maps, and the main difference is that the great southern landmass, which was also present in, for example, Ortelius' maps, are populated in Mundus. In fact, for Hall, this landmass is to put it in Milton's previously quoted words - "the mighty continent" where he can "display the largenesse of their spirits". The governing fiction is a geographical one, and it is further elaborated by the mentioned association between reading and travelling. As we will later see, the maps are also important parts of the moral agenda behind the work, but they might also serve as another link with travel literature. ${ }^{150}$

The rest of the paratexts are quite similar in nature. The marginalia, the different embedded elements (inscriptions, drawings etc), together with the etymology of the place names used in the book are auxiliary elements which lend more "academic" authority to the text. McCabe $(1982,80)$ claims that the marginalia in fact creates a bynarrator, a "detached scholarly observer" for the book, and he thinks that thus the work becomes a "burlesque not merely of the travelogue, but of the contemporary academic textbook as well" (Ibid). Such an interpretation is, in my opinion, strengthened by the

\footnotetext{
149 The most extreme example I have encountered is the article by Bishop, who interprets Holbein's map of Utopia as a work in the "memento mori" tradition. Interestingly, the article was published in the British Dental Journal, and "[d]raws attention to the part played by experience in dental radiology in heightening the perception of concealed anatomical structures.” See Bishop $(2005,107)$.

${ }^{150}$ For example, Hakluyt's Diverse voyages touching the discovery of America... (1582) contains two folded maps (STC $2^{\text {nd }}$ ed, 12624, http://estc.bl.uk/S105954).
} 
paratextual changes introduced in Healey's translation, since the most serious modifications are related to this group: the maps and the etymology are deleted, while Wands claims that Healey deletes many of the marginal notes, or replaces them with comments of vastly different nature. ${ }^{151}$ These changes are obviously related to the difference in the intended audiences, but at the same time, they also do some damage to the reading-as-a-journey allegory, too.

With this group, we reached to the question of the changes in Healey's English version. As noted, the only changes besides those in connection with this latter group are the extension of the dedication (to a new dedicatee, nr. 2. in the table above), and the replacement of Knight's preface with a new preface to the reader by Healey (nr. 3. in the table). Despite its extended length, the dedication to the Earl of Pembroke delivers nothing new, and in a humble, flattering tone, asks for the protection of the dedicatee. The only place where this passage seems at least to try and become a bit more original, or at least to come close to its original is when it, in fact, tells at last something about the book itself is the last section. Healey employs here the basic ambiguity ("alter et idem") of the title to compose a salutatory formula of some wit:

A discouerie and no discouerie, of a world and no world, both knowne and unknowne, by a traueller that neuer trauelled. Written first in Latine and no Latine, and now translated, and yet not translated, by the same man, yet not the same man that first of all pend it. (Discovery 1613, $\llbracket 3 \mathrm{r}-\mathrm{v}$ )

Healey's addition to the paratexts, the instructions for the reader, is much more interesting. In this short preface, he clearly develops the same allegory as Hall: the book is a journey, for which he, the translator gives a new guide book, in accord with his

${ }^{151} \mathrm{Cf}$. Wands (1981b, lvi). He claims here that "With the loss of these [notes with references to classical authors] the translation appears far less learned." 
evaluation of his own translation: "it hath no further alliance to his, then chalke hath to cheese" (Discovery 1613, $\llbracket 2^{\mathrm{v}}$ ). Most of the preface is devoted to weaken the link between the original author and the translator, and between their works. The final paragraph, however, further develops the original prefatory allegory:

And know all you (...) that you must first of al take one of that French Doctors pills (...) and this will enable you fully to endure the alteration of all ayres in this clime. Secondly you must neuer trauell single, but two, or three in a company, for one you know may apprehend more then another can, and those before, that haue miscaried in this voiage, as you haue heard, incurred their misfortunes onely by neglecting this direction, and by too much conuersing with those of the Foolianders nation. Thirdly, you must go ouer the country thrice, ere you shalbe able to make any exact platforme of it: Once for Strabo, once for Socrates, and once for Merlin Cocaius; The first for the Geography, the second for the Morality, and the third for the Language, and Etymology. No more at this time, but aboord when you please and a good gale of wit go along with you.

The first two hints are furthering and overstressing the allegory of the journey, although in the case of the second, one may wonder: does this mean that Healey recommends the book to be read by two or three persons simultaneously? If yes, what kind of warning is implied here? Is solitary reading a dangerous exercise? Whatever the answers to these questions are, the third recommendation, is Healey's probably most important addition to the whole work. If the allegory of reading as a journey was not convincing up to now, here we receive an explicit treatment of it. If Healey's translation is indeed intended for more meagre audiences, the proposal to read the book at least three times is a quite sophisticated view. The hierarchy of reading objectives (first geography, then moral, then language) might, nonetheless, not exactly match the original conceptions of Hall. In order to grasp this, in the following subchapter, I would like to take a more detailed view at a certain part of the work, hoping to show that the 
original primary intention was not geography, but moral, and that this hierarchy brings the text closer to the world of the Elizabethan dialogues, too.

\subsection{Moral issues in Mundus and the Elizabethan dialogues}

In this subchapter, I would like to place one part of Mundus (the second book) in the broader context of the social issues it might be related to. This way, I would like to show that despite all the formal similarities with More, the work also shares many important features with the Elizabethan dialogues. Those were evidently fuelled by a fervent Puritan desire for moral reform, and social and moral issues are central to Mundus, too. In order to prove this, I would like to link the second book (describing the land of women) to contemporary discussions about cross-dressing and other related issues, and show that the way this subject is handled by Hall might have something to do with the Elizabethan dialogues. ${ }^{152}$ Before showing out textual analogies, however, it seems useful to take a wider look at the critical debates around two of the subjects discussed in Book II: cross-dressing and hermaphroditism.

It is quite obvious that in the early modern era, when dress code was centrally regulated by so-called sumptuary laws prescribing the attire to be worn by people of different social ranks, both male to female and female to male cross-dressing posed a threat of some kind to established power relations. The precise extent and nature of this threat is heavily debated in critical accounts of the phenomenon, but the complexity of

\footnotetext{
${ }^{152}$ This chapter is an abridged version of my previous article on the subject. See Maczelka (2012).
} 
the issue is generally acknowledged. ${ }^{153}$ The problem is all the more complicated when dealing with English Renaissance theatre, which was employing exclusively male actors, a feature that Stephen Orgel sees as "anomalous" in comparison to other European countries where either women were allowed to play, or theatre in general was forbidden (Orgel 1996, 1-2) . No wonder that English Renaissance theatre is one of the predominant areas of critical discussion about the phenomenon, and that in the 1980s, Laura Levin, Stephen Greenblatt, Jean E. Howard and others addressed the problem precisely within this context. A corpus particularly relevant to the issue from this perspective is the $16^{\text {th }}-17^{\text {th }}$ century Puritan anti-theatrical polemical literature. When giving voice to their harsh critique against theatres (and, it cannot be emphasised enough, against many other "abuses" as well), authors like William Prynne, John Rainolds, or the already mentioned Philip Stubbes frequently touch upon the issue of cross-dressing, like in the below quotation from the latter:

Our apparel was given us as a signe distinctive to discern betwixt sex and sex, \& therefore one to weare the Apparel of another sex, is to participate with the same, and to adulterate the veritie of his owne kinde (Stubbes quoted in Howard 1988, 420) .

The third corpus pertaining to the subject is of vastly different nature. These are actual court records of cases against cross-dressers, a body of text which Jean Howard makes extensive use of in her seminal article published in $1988 .{ }^{154}$ Interestingly, while in Howard's interpretation, such cases are another proof of a "sex-gender system under

\footnotetext{
${ }^{153}$ The secondary literature on cross-dressing is enormous. I will only refer to some of the many available critical opinions. For a recent treatment of the phenomenon, see Szőnyi (2012), who lists a lot of related works in its bibliography.

${ }^{154}$ It must be immediately noted that in the newer version of her article, Howard has added some preliminary notes to her paper, the most important probably being that "In this chapter I no longer speak of a sex-gender system as a single phenomenon Howard (1994, 162, n.1.)." However, the basic structure and the conclusion are not significantly changed by this addition.
} 
pressure (Howard 1988, 418)," in the historian David Cressy's evaluation of similar material, they appear in a completely different light. Cressy revisits Howard's claims, and based on the "remarkably mild" sentences in the legal cases examined by him, as well as on a different interpretation of cross-dressing in some contemporary plays, he arrives at the conclusion that "neither the records of ecclesiastical justice nor the London comedies reveal, in my reading, a sex-gender system in crisis (Cressy 1996, $450,464)$." Analyses of Renaissance cross-dressing predominantly rely on the above listed types of sources, namely: plays, anti-theatrical tracts, and juridical records, occasionally complemented with other types of texts (anatomical tracts, royal proclamations, homilies etc.) as well. ${ }^{155}$

In what follows, I would like to show that even if in a slightly different way, Mundus is involved in this question. As we are turning our attention towards the second book describing the land of woman, we should keep in mind McCabe's opinion that Hall was "neither philosopher nor theologian, but an impassioned devotionalist deeply convinced of the moral efficacy of imaginative literature" (McCabe 1982, 2).

Like all the parts, this section also begins with a short general description of the land, performed in the usual manner of travel books, but it also contains a rather ambivalent remark:

The soile thereof is very fruitful, but badly husbanded: It is divided into many Provinces, both large and ritch, yet all of severall conditions, habites and languages. (Discovery $1613 \mathrm{H} 1^{\mathrm{r}}$ )

155 On contemporary anatomical views, see Greenblatt (1988, esp. 73-86), and also Orgel (1996, esp. 1824). Royal proclamations and the homily Sermon against Excess of Apparel are studied by Garber (1997). 
The first clause obviously submits itself to utopian conventions, plenty being one of the persistent features of utopian landscapes. However, through the pun on the double meaning of the word "husband," Hall suggests that the land of women cannot be an ideal place, and the reason for this is the diversity of "conditions, habites and languages," which in turn is caused by the lack of proper cultivation. The text implies here that a land ruled by women, or rather: unruled by men necessary leads to confusion, but on a less institutional level, it simply means that the "unruly" woman represents danger. Correspondingly, Howard argues that female to male cross-dressing was interpreted as a sign of unruliness, which represented not only the danger of sexual licence but was also seen as a threat against the state (Howard 1988, 425). The concept of unruly women as dangerous in Mundus clearly initiates a remote link with crossdressing already at this early point, and therefore it is all the more remarkable that besides conditions and language, the third area of confusion is "habites," and also that Wands's translation only includes "character and custom" in the same place (Another World 1981b, 57).

This preliminary opinion gains more relevance after a rhetorical twist in the second chapter, which lends some instability to the narrator's position. Since Mercury arrives from the land of the arch-enemies of the women, Lecheretania, he enjoys a rather cold welcome, and only the name and the fame of his country can save him: "Well to warde I went, and but that my countries name (the true Paradise of women) pleaded for me, I had never come home alive" (Discovery 1613, H2v ). Despite England's favourable reputation (which Wands leads back to a saying popular in the 1590s), the narrator has to accept certain laws, and thus we encounter another typically utopian textual element. The laws are incorporated into the chapter, and open a rather wide window upon general contemporary stereotypes about women, reflecting a bunch 
of supposed female desires like the possibility of talking without interruption, being the ruler of the house, male constancy and monogamy, a respect for female privacy. From the perspective of the narrator's position, the last law is of paramount importance:

That I should continually give women the prick and praise for beauty, wit and eloquence, and defend it against all men. (Discovery $1613, \mathrm{H}^{\mathrm{r}}-\mathrm{H} 3^{\mathrm{v}}$ )

Mercury thus subjects to a law which imposes limits on the scope of his narration. Since this happens at the very beginning of a book dedicated to the description of the land of women, the rest of the book must be taken with a grain of salt, since negative judgments must by agreement be suppressed. The narrator himself refers to this ambiguous position, claiming that "my tongue is tied by mine oth (...) Somewhat I may say, but no harme" (Discovery 1613, H3 ${ }^{\vee}$ ).

The narrative follows the usual structure of Mundus, displaying the form of government and the system of elections. This part is again full of negative stereotypes against women, and introduces a totally confuse, inconstant system, where the two most important virtues are Beauty and Eloquence. In a sense, this chapter is the illustration of the very beginning of the book, suggesting once again that if women are their own rulers, confusion necessary arises. This is expressed almost word by word when the female system of democracy is described in the following manner:

Their state (for ought I could observe) is popular, each one seeking superiority, and avoiding obedience. (Discovery 1613, $\mathrm{H} 3^{\mathrm{r}}$ )

Remarkably, the Latin original uses the word democraticus instead of popular, yet from our present perspective, it is more important that the self-ruling women of Shee-landt seek the privilege of men (superiority), and consequently, lose what seems to be in Hall's opinion their own principal virtue, obedience. Obedience of women is one 
of the central subjects women in A pleasant dialogue, too. Listra's submissive, onedimensional, static figure is the proper example of the ideal woman, but the dialogue frequently reflects on the question in more direct terms, like in the below quote, where the pilgrim replies to Listra's question concerning women in Crangalor:

Pilgrim: Very honest and virtuous they [women in Crangalor] are Madam. For in that Citty, you shall not see neyther Wiues, nor Maydes with hand Baskets, or otherwise wander about the Citty, because the Husbands and theyr menslaues prepare all necessaries, for their houses and families: so that the women straye not abroad, except on the Sabboth day, or tother festiuall dayes. (A pleasant dialogue 1579, Bviii $^{\mathrm{v}}$ )

Switching back to Mundus, we see that the position of the narrator becomes problematic by the time we arrive to the parts which are relevant to the topic discussed here. The title of chapter six is Of Double-Sex Isle, otherwise called Skrat or Hermaphrodite Island, and it represents a land where everything has a "double kind," even nature itself is full of weird dualities with fruits like cherry-apple and datealmond. But it is the inhabitants of this island who are particularly interesting for the problem of cross-dressing:

Yea in so much that the very inhabitants of the whole Iland wore all their habits as Indices of a coaptation of both sexes in one. Those that bare the most man about them, wore spurres, bootes and britches from the heels to the hanshes: and bodies, rebates and periwigges from the crupper to the crowne; and for those that were the better sharers in woman kind, they weare doublets to the rumpe, and skirts to the remainder. (Discovery $1613 \mathrm{H} 8^{\mathrm{r}}$ )

Needless to say, the word Indices is the key to this passage, as it refers to the primary function of the sumptuary laws in effect at the time, which was to render class and wealth positions legible (Garber 1992, 26). The cross-dressing acted out by these hermaphrodites is much different from the cases discussed by Howard, Cressy and 
others, where cross-dressing means appearing in the opposite sex's attire. In Mundus, hermaphrodites wear male and female clothes simultaneously, a condition quite similar to a case noted down in the mid-seventeenth century diary of the physician John Ward, recounted in Ruth Gilbert's monograph on early modern hermaphrodites:

An hermaphrodite at a place 4 miles of Worcester: his testicles large and his penis out of measure big yet unfit for generation as my Landlord said he did believe. I and Mr.Trap saw him. Hee goes dressed upward as a woman in a kind of wastcoat and Bodies: but Breeches on. (John Ward quoted in Gilbert 2002, 2)

On the Isle of Hermaphrodites, this type of "dual" cross-dressing is not so much a means of transgressing gender boundaries, but an outward sign of the double-sexed nature. In "their conceite" the inhabitants of the isle consider themselves to be in possession of "the perfection of nature," and it must be strongly emphasised that the narrator himself comments upon this duality in the following manner: "truly you may observe in them all, besides their shapes, both a mans wit, and a womans craft" (Discovery $1613, H 8^{v}$ ). At first glance, we seem to encounter here an island where the hermaphrodite is "an elevated ideal, the perfect union of opposites" (Gilbert 2002: 9).

Yet, despite the narrator's apparent approval, ambiguity lingers through the concept of hermaphrodites in Mundus. Remnants of conventional sexual distinctions can be observed, and these govern the direction of the "dual" cross-dressing. Some "bare the most man about them," while others are "the better sharers in woman kind," and the kind of dress they wear is an indicator of the dominant sex in the given individual. The dominant sex is also indicated by the names: "Mary Philip, Peter-alice, Iane-andrew, and George-audry" (Discovery 1613, H8 ${ }^{\mathrm{r}}$ ). It is clear that dressing, crossdressing, naming, and sexual identity are closely linked in the description of the 
hermaphrodites in Mundus, and there are similar instances of this association in Hall's other books. Both in his early satirical work Virgidemiarum (1597-8), and in his later sermons, he engages in rather fervent attacks against cross-dressers, and at least in one place he refers to them as "the hermaphrodites of our times" (Wands 1981b, commentary on 158). The same association appears in other works written against cross-dressers, like in the famous Hic Mulier tract from 1620, where cross-dressing women are again referred to as "new hermaphrodites" (Hic Mulier quoted in Howard 1988, 425). Therefore, the idealistic image of hermaphrodites in Mundus must be handled with caution. Although the narrator seems to be approving, he also refers to the hermaphrodites" "conceite" and "deformity," and in the typical satirical inversion of values, retells the hermaphrodites' opinion about single-sexed persons: "what a coile they keepe about them, shewing them as prodigies $\&$ monsters, as wee doe those that are borne double-headed, or other such deformed birthes" (Discovery 1613, H8 ${ }^{\mathrm{r}}$ ). All in all, the isle of hermaphrodites in Mundus reinforces Gilbert's observation about the plurality and instability of the meanings associated with the early modern concept of hermaphroditism (Gilbert 2002: ch. 1., esp. 9-10). On the other hand, the instability of meaning, of course is not far from the "ambiguous terms" which are mentioned in the Occasion.

The last chapter of Book II is an account of the country called Shrewes-bourg, where gender roles are completely interchanged. Here again, dress and outward appearance is of central importance; indeed, these make Mercury soon realise that the land is out of joints:

Here was I truly guld; for espying persons in the habites of men, masse thought I, this is good, I am now gotten out of Womendecoia: but when all came to all, I was flat cousned with a borrowed shape: for in this countrie 
women weare britches, and long beards, and the men goe with their chinnes all naked, in kirtles and peticoates; spinning and carding wooll, whilest their wives discharge the main affaires of the state. (Discovery $1613, \mathrm{I} 1^{\mathrm{r}}$ )

The very first sign marking the mixed up gender configuration is once again the garment, and only after this comes the transposition of functions, as if it would be but a consequence of cross-dressing. Yet the interchange of functions is rather far-fetched: in fact men do everything that conventionally women were supposed to do, while women enjoy all the privileges that were inaccessible for them in the contemporary maledominant patriarchal system.

Dressing and cross-dressing plays a pivotal role in the rest of the chapter as well. At one point Mercury compares the enslaved men of Shrewes-burg to Turkish slaves, and finds "that these distinction of habites assured mee this was a more base kinde of captivity (Discovery 1613, I2 $2^{\mathrm{r}}$ " - but the section may be more straightforward in the modern translation:

It would have appeared to me that I was walking among some Turkish slaves, had not the dress that distinguishes them showed me it was an even baser kind of slavery. (Another World, 64)

The most prominent link between Mundus and the Elizabethan dialogues, however, is the topic of charivaris and skirmingtons. In the secondary literature on cross-dressing, these frequently recur, for example, Howard treats them as unofficial occasions where "unruly women were disciplined and insufficiently dominating husbands reproved" (Howard 1994, 103). Such a collective enactment of gender tensions is described in an episode in Shrewes-burg - but with the role of the man and the woman exchanged: 
She must first change attires with her husband, and then shave off all her haire, and so being ledde through the market place must stand for one whole daie upon the pillorie, as an object unto all the fleering scoffes of the beholders, nor shall the man escape scot-free, for being so audacious, as to take the favours offered by his wife without a modest refusal. (Discovery $\left.1613, \mathrm{I}^{\mathrm{r}}\right)$

Once again, the importance of dressing and cross-dressing is re-confirmed, the change of attire being the most substantial part of the punishment of the wife who let his husband loose: she can only put his normal clothes back after she has presented a cudgel covered with the blood of the unruly man in front of the court.

This is the point where the seemingly too lengthy discussion devoted to the subject hopefully becomes justified. Although Wands's indispensable edition of Mundus contains extensive commentary, which is at times related to the issues discussed above, in most of the cases his explanations refer either to the classical sources of Hall, or to analogous places in his other works. Therefore, in the commentary attached to the above section, there is no trace of a strong and interesting parallel between Mundus and the works discussed in Chapter 3. In A pleasant dialogue, the Pilgrim illustrates the equity Crangalor's judicial system with three examples. The described cases are perfectly fitting into the discussion at hand, so it is probably worth to quote this section more extensively:

[a woman]was conuicted of Sorcery \& Witchcraft, but no hurt doone by her to either man or beast, approoued: yet for her dealing in that arte, she was condemned. The execution was, she was set upon an Asse, her body naked unto her Nauill, and annoynted all ouer with Honny, the which was beset fill of small feathers of Down, with a Miter on her head, of a yarde long, and in this sorte she rode about the streets accustomed, with a Trumpet blowen before her, and a Cryer manifesting her offence. (A pleasant dialogue 1579, $\left.\mathrm{I} / \mathrm{Biii}^{\mathrm{v}}-\mathrm{Biv}^{\mathrm{r}}\right)$ 
The other case is interesting because a similar type of punishment is used against a man, but for a crime unrelated to the gender issues: perjury. The first two examples suggest that this type of punishment, after all, was not reserved for sexual licentiousness (although this might be our impression based on critical opinions), but for other types of crimes, too. The last example, however, seems to bear an almost textual resemblance with the part quoted from Mundus:

The thyrde person that I saw punished was a wittoll and he I say, rode upon an Asse about the sayd streetes, with a Hartes horne on his head ful of small Bels, and his wife rode after whipping him, and then followed the hangeman whipping them bothe. (A pleasant dialogue 1579, I/Biiii ${ }^{\vee}$ )

All in all, these analogies are important for at least two reasons. First, they warn us that despite all the literary craftsmanship applied by Hall, his work is not simply a witty youthful venture, "holiday literature". The ambiguity proposed in the introduction is preserved throughout the second book, but as we saw, the self-negating, ambivalent construction of the narrator is used here in order to reflect upon the most complex, no less ambivalent social issues. Second, in the case of the charivaris and skirmingtons, such a similarity shows between Mundus and A pleasant dialogue that it might suggest direct textual influence. ${ }^{156}$

\subsection{Summary}

As it has hopefully become clear, Mundus is a synthesis of the developments we have identified in More and his early English followers in many respects. The paratextual space is used with Morean craft, and it provides a complex allegory of

\footnotetext{
156 And as noted above, Lupton's mentioned work also contains a hauntingly similar description.
} 
reading that spans over the whole book. The contemporary English translation by Healey, on the other hand, although aims at a different kind of audience, seems to be similarly aware of the functions and potentials of the paratextual elements, and even if he removes important elements (maps, marginalia), at least in the prefaces, he is capable of similar self-reflexivity as Hall and Knight in the Latin.

A detailed look at the second book, however, uncovered different, previously unexplored allegations. It is obvious that despite all the elaborate formal features, the masterful imitations of and the innumerable allusions to More, the work is not simply a direct descendant of Utopia. The way the form is put to use creates a link between Mundus and the utopian dialogues. Hall's monographer is right in summing up the work as an "allegorical 'dystopia' primarily concerned with satirizing the vices" (McCabe 1982, 74). If we read the work in this way, then its geographical facet becomes less realistic, and we might agree with McCabe (1982, 98), who argues that the work's geography is to be understood as a moral topography. In this sense, the structure of the world, and thus the parallel structure of the work are subject to a higher moral aim, where the description progresses according to the different kinds of sins, as seen in the table below, based on McCabe (1982, 100-1):

\begin{tabular}{|l|l|l|l|}
\hline Book & Hall & Healey & \multirow{2}{*}{ Vices (McCabe) } \\
\cline { 1 - 3 } 1. & $\begin{array}{l}\text { Crapulia } \\
\text { Yvronia }\end{array}$ & $\begin{array}{l}\text { Tenter-belly } \\
\text { Drink-allia }\end{array}$ & \multirow{2}{*}{ sins of flesh } \\
\cline { 1 - 3 } 2. & Viraginia & Shee-landt & \\
\cline { 1 - 3 } 3. & Moronia & Fooliana & \multirow{2}{*}{ sins of mind } \\
\cline { 1 - 3 } 4. & Lavernia & Thee-uingen & \\
\hline
\end{tabular}


Thus the whole structure of the work is subjugated to the underlying moralistic agenda. In this, we might see a tendency that was beginning with the Elizabethan dialogues, which made a feeble attempt at using the utopian form for serious matters. The feebleness arose from the contradiction between utopian form and anti-utopian sentiment. Hall goes one step further. While he is obviously aware of each and every bit of the Morean model, he uses it to support his basically anti-utopian attitude. It is probably this anti-utopian sentiment that makes Hall such a sensitive user of the utopian form. ${ }^{157}$ In my opinion, the gap between the sentiment and the form is already beginning to open up in the Elizabethan works, and here is the point when the two finally split. During this separation (maybe because of it?), however, the dialogic aspect of the work becomes less important, and plays a significantly reduced role.

In my opinion, the most attractive feature of Mundus is that all these changes take place in a deeply reflected way. In the English utopian tradition, Hall appears to be the initiator of a new tradition of more confident paratextual self-reflexivity, which becomes so characteristic in later utopian texts, and centres around the notions of "fiction," "fancy," "imagination," and their synonyms. In the closing chapter, I would like to offer a few examples to this self-reflexivity, which serves also as an exploration of possible further research directions.

157 Compare this with the following opinion by McCabe (1982, 100-101): "Hall was suspicious of Utopias, and Campanella's fanatical and disastrous attempts to realize the plans of The City of the Sun (with which the Mundus was republished in 1643) can only have served to justify his own choice of 'dystopian' satire." 


\section{Conclusion}

My dissertation proposed to show the use of paratextuality and the dialogue form in English utopias from More's Utopia till the second half of the seventeenth century. Due to the complexity of the issue, a more detailed investigation could only be carried out until the beginning of the seventeenth century. The more detailed look, however, hopefully resulted in conclusions which revealed not only previously unknown connections between different works and generic traditions, but they hopefully produced at least a number of considerations which can be utilised in the study of later specimens, too. In my conclusion, I first offer a brief review of my results, and then move on to show how my final considerations are reflected in some later English utopian texts.

\subsection{Results}

The basis for my thesis was the observed neglect of literary and formal aspects in secondary literature. This was narrowed down to the examination of the use of the paratexts and the dialogue form, a selection based on the presupposition that these two areas might reveal important insights into the more general subject of fiction in utopias. At this point, when summing up the results, one is naturally tempted to think in terms of trends and continuites, as it is very hard to escape the temptation to think in a closed, clear-cut, linear historiographical narrative. With this in mind, I would like to sum up the results with at least an attempt at calling attention to important differences, too.

The second chapter of my dissertation offered a detailed look at Thomas More's Utopia. If the space devoted to the work might seem extensive, the unequal proportions are justified by several reasons. First, the two focal aspects of my thesis are most prominently 
present in this work. Another reason for the space devoted to Utopia is related to some scholarly opinions (discussed in more details in the Introduction) which question the existence of a utopian textual tradition, making it a key task to look at the ways in and the extent to which More's work could become a model.

In terms of paratextuality, the most important result was the identification of a consistent thread of ideas related to poetics and literary theory, which is present in almost all of the prefatory material of Utopia. This thread is using the language of tracts on poetry and literature, and promotes literature's superiority based on its representative capacity. Another aspect occurring with similar consistency is the profound ambiguity in both tone and content. With a few exceptions, almost all paratexts are taking part in the fiction of the main text, but they clearly show a tendency of undermining it at the same time. With the excessive number of paratextual elements surrounding the text, and the consistent presence of these two features, serious influence is imposed upon the reader by the time the beginning of the "main" work is reached. This way, the parerga becomes more than an instruction for the work: it is an inherent part of it, and should one read the book without these seemingly additional, but in fact, organic parts, it would be easy to miss the point, as so many have missed it from the earliest times. The most important point, based on what the paratexts of Utopia tell us, is that we should not take the marginal position of the paratext for granted. In this sense, Genette's term (threshold), but any possible alternatives (preliminary, parerga) might draw too sharp a line between the literary work and what it is bound together with.

The other aspect, the investigation of the dialogue form also proved fruitful in connection with Utopia. Starting out from the two-book structure, I have tried to read the work in line with the praeparatio/contention division drafted by $16^{\text {th }}$ century Italian theorists of the genre. More's work responded extremely well to such an approach. It was not hard to identify the inevitable requirement of Renaissance dialogues (a thesis) in Book I, and 
although Book II shifts to a more narrative style, it can definitely be read as the probe of that thesis uttered by one of the interlocutors, Raphael. This finding becomes truly revelatory if we also notice that besides employing the form, Utopia also transmits its own reflections on it. Book I contains a more or less hidden (hidden at least in some translations) thread of contemplation about the nature of conversation, and uses terms (sermo, colloquium, decorum) which are clearly and explicitly linked to the theories of dialogues. Furthermore, since the paratextual elements also clearly mirror the ethos of humanist conversation, the two aspects are always intertwined in the work, and show the playfully ambiguous attitude of Utopia to its own fictitious nature.

The third chapter looked at one of the earliest English imitators of More's book. Thomas Nicholls's A pleasant dialogue was read in light of what I have found in Utopia, and it soon became clear that there are many connecting points between the two works. The similarity is above all formal: the two-book structure is a conscious effort at reproducing the original model, as is the change from the dialogue form to a more narrative one in the second part. There were at least some remote reminiscences in the use of the paratexts as well, but intense self-reflexivity was not to spot here, even if some of the playfulness and a much reduced extent of ambiguity (a fictional character writing to a real character) is preserved. The dialogue form is an important aspect of Nicholl's work, however, here some important differences have been observed between Utopia and A pleasant dialogue. The later work builds a connection with another genre: the Tudor polemical dialogue. Even if these two types of dialogues are obviously not independent from each other, the work thus appears in a completely different light. Following this thread I proposed that further research should read the work together with two other utopian-polemical dialogues of the time (by Stubbes and Lupton), and the wider context of the popular Elizabethan polemic literature should also be taken into account. However, if self-reflection was not eminent in the paratexts, there were at 
least some interesting reflections in the main text itself. These reflections proposed a reading method which focuses on extracting the Christian moral from the story at hand, be it a fable or the description of a dramatic production. This reinforced the link with polemical-moralistic literature of the period, and suggested some anxiety with the use of fiction on Nicholls's part. Instead of the polychromatic world of Utopia, Nicholls's work, together with the other related dialogues, delivers a more monochrome, teleological use of the form. More's work is a remote model, and not the only model in working here.

The fourth chapter discussed Joseph Hall's work, and if he is described by his modern translator as someone trying to avoid "all extremes in an age when extremity seems to have been a norm" (Wands 1981b, xx), he is similarly away from the two extremes represented by More and the Elizabethan dialogues. His use of paratextuality and in fact, of all the formal elements in the book is clearly in imitation of More. Yet, he also builds on many other sources and traditions, so travel books, to give only one example, have also inspired some of the paratextual elements of the work (like the realistic maps, the etymology of names, word lists, etc). Another link with the Morean model is the self-reflexive thread interwoven in the prefatory material, which compares reading to travelling. On the other hand, in the description of the land of women, he might be relying on the Elizabethan precedents. Even if the extent of specific textual resemblance may be hard to pinpoint, it is clear that the form invented by More is used here in a manner more characteristic to those of the dialogues. In a sense, Hall's work is a fusion of English utopian literature before him. While the dialogues were not completely assured about the use of fiction for the objective of moral admonition and reform (that is why they tried to strictly determine the ideal reading of themselves), the difference is that Hall was completely convinced about it. Nonetheless, a strong attempt at determining the methods and purpose of reading is again palpable in the allegory of reading as a journey, a journey where (moral) profit is probably more important than pleasure (even if Kinght's 
argument for the unlicensed publication is the beauty of the work). The sense of control is even stronger in Healey's translation, where the allegory is not simply identified and continued, but also made less subtle, bringing it closer to the dialogues. Probably we are not far from the truth when I suggest that the quick translation of Hall's work into English is explained by the affinity of Mundus to the Elizabethan utopian dialogues.

Even if the sense of continuity is getting suspicious here, there are a few certainties. To variable extent, each of the texts show awareness of the aspects discussed in my thesis. While some make only a limited use of paratexts, this use always reflects the desire of control over the reading of the text. While in this space, Utopia stresses the profound ambiguity of itself, A pleasant dialogue tries not to be too ambiguous, and Hall and Healey also seem to make restrictions on the scope of that ambiguity. All of them, nonetheless, try to point out the direction for the desired reception of the work. The dialogue form also shows great variance within the works, but it is similarly present and more or less acknowledged and reflected in each case. It is this position from which a brief review at some later uses of these elements should be performed.

\subsection{Later texts}

\section{New Atlantis}

The next big step in English utopian literature is evidently Francis Bacon's posthumously published New Atlantis. The work appeared together with Bacon's Sylva Sylvarum, or a Natural History in 1627. With the preamble that New Atlantis would deserve if not a separate dissertation than at least a chapter of its own, I would like to briefly refer to the specific questions I have employed throughout my work. In proximity to the subject paratextuality, the pairing of the fictitious text with a scientific work (scientific at least according to contemporary standards) is a novel feature, no wonder that the only paratext available, the 
editor's preface finds it necessary to reflect upon this juxtaposition. William Rawley's address to the reader highlights that the work is "unfinished", and he explicitly identifies its purpose:

This fable my Lord devised, to the end that he might exhibit therein a model or description of a college instituted for the interpreting of nature and the producing of great and marvellous works for the benefit of men, under the name of Salomon's House, or the College of the Six Days' Works. (Bruce 1999, 151, my italics)

Even if these are not the words of Bacon, the reflections in this passage are important for the present purposes. First, by using the word 'fable,' Rawley broadens the catalogue of terms associated with the fictitious nature of utopia. The use of precisely this term is significant, on one hand, for the long and variegated tradition of a distinction of historia and fabula in rhetoric. ${ }^{158}$ On the other hand, one should also notice the use of the word 'exhibit' here. As noted above (in chapter 2.2), one of the prefatory poems for Utopia argues for the prevalence of literature over philosophy because it is not simply capable of describing an ideal state, but also of "exhibiting" it or "making [it] live". Not only the terms, but the whole argument of Rawley is similar to those used in the Hexastichon, but in this case, the distinction becomes even more relevant, because the work preceding New Atlantis is, indeed, a work of philosophy. Instead of the hierarchy proposed in the poems surrounding Utopia, the relationship between philosophy and literature is complementary in Bacon's case.

As for the aspect of dialogicity, it also witnesses important changes in New Atlantis, and the greatest of the many instabilities in the work are also touching upon this question. While all the utopias discussed before offered a longer (More) or shorter (Nicholls, Hall) introductory conversation, and usually a set of prefatory material, which is followed by the description of the displaced land, one of the most shocking aspects about Bacon's utopia is

\footnotetext{
${ }^{158}$ For a general overview of the development of these concepts, see for example Bietenholz (1994), esp. chapter 4 (The Renaissance Period).
} 
that it commences in an "in medias res" fashion. ${ }^{159}$ That does not mean, however, a complete neglect for the dialogue form. In fact, dialogue becomes the most important narrative device in one part of the text, the channel through which the knowledge of the new world transits into the old. In this sense, it is all the more disturbing that we know nothing about the interlocutor. ${ }^{160}$ It is clear that the application of the dialogue form is nothing but a perfunctory device in the hands of Bacon, an element needed to produce the effect of verisimilitude. That this was, indeed, the desired effect of Bacon's "fable" is also evident from the preface to the work printed together with New Atlantis:

I will conclude with an usual speech of his lordship's; That this work of his Natural History is the world as God made it, and not as men have made it; for that it hath nothing of imagination. (quoted in Salzman 2002, 44)

Another key term appears here, and indirectly, it again emphasises the appeal (but in Bacon's case, probably only a limited appeal) of the evolving utopian genre: imagination. Without going deeper into the complex issues surrounding More's work, let us just call attention to the fact that in Bacon's work, one of the first utopias without prefatory materials and only a reduced role of dialogue was born. ${ }^{161}$ As we will soon see, these innovations were not necessarily followed by later writers.

\footnotetext{
${ }^{159}$ In Salzman's reading, the fact that the writer of New Atlantis "turns his back on the multiple, ironising frames within which More places his narrative" brings the text closer to travel narratives, and their purpose of persuasion, even if Bacon wants to persuade the reader not about a colonial venture but about a new scientific paradigm. See Salzman (2002, 32-3).

${ }^{160}$ As Salzman $(2002,37)$ puts it, Bacon's "narrator is without any clear identity; indeed, he is something of a cipher".

${ }^{161}$ According to Boesky (1997, 143), Bacon's text is "a collection of broken or incomplete prose kinds aphorisms, dialogues, experiments, fables", and contains "a series of dialogues or interviews, each curiously interrupted or broken off".
} 


\section{Macaria}

Gabriel Plattes's A Description of the Famous Kingdome of Macaria (1641) is a significant control-example for the present project. ${ }^{162}$ The proposal-like text has an open social-political objective, and this objective is reinstated several times in the text and also in its important preface. Therefore, if I said that in Hall, anti-utopian sentiment meets the utopian form, we might say that in Plattes's text utopian thinking meets utopian form (again). That form, on the other hand, is dialogic, promoted again already on its title page: "In a Dialogue between a Schollar and a Traveller" (Plattes 1641, A1r). The text is also unique in the sense that it is probably the shortest of all the texts discussed. This brevity probably determines a limited use of the paratextual space, as the 16 pages strong text obviously cannot compete with, for example, Utopia, where the combined length of the paratexts surpasses the total length of Macaria.

Thus, the text only provides one short paratext besides the title page, but it includes significant novelties. First of all, the work is dedicated not to a person but "to the high and honourable court of Parliament" (Plattes 1641, A2r). In the same vein, the preface situates itself within the actual political setting. The most important passage is an excuse for the selected form:

I have adventured to cast in my widowes mite into the Treasurie; not as an Instructer, or Counsellour, to this Honourable Assembly, but have delivered my conceptions in a Fiction, as a more mannerly way, having for my pattern Sir Thomas Moore, and Sir Francis Bacon once Lord Chancellour of England. (Plattes 1641 A2r-A2v)

\footnotetext{
162 The text is often attributed, even in critical literature, to the great "intelligencer" Samuel Hartlib. However, the question of authorship was settled by Charles Webster, see Webster (1972, 34-48). The utopianism of the Hartlib Circle is discussed in Dickson's book, but utopianism is understood there not as a literary tradition, in line with his drive (based on Jerome McGann's principles) to "see the literary or cultural text as a social product" (Dickson 1998, 4).
} 
The passage testifies to the quick success of New Atlantis: in less than two decades after its appearance, Bacon's work is on par with Utopia. For our present purposes, the use of the word "fiction" here is even more interesting. From Hall onwards, we have realised a thread of conscious, implicit (Hall's naming of the ship carrying the reader: "Phantasia") or explicit ("fable" by Rawley, "imagination" by Bacon) tendency in referring to the works' own fictitious nature. This is, however, the first use of "fiction" in the reviewed early modern utopias. ${ }^{163}$

Significantly, no gap between the fictional form and the pragmatic real-word purpose is felt. Just like the dialogue form it employs, the utopian narrative is only one out of a number of possible rhetorical devices to be applied for the greater task of distributing knowledge. Correspondingly, the dialogue form employed here is crude and didactic. The speech between the two figures (scholar, traveller) resembles mostly Campanella's City of Sun, as the figures are not characterised at all, serving only the purpose of conveying the message.

While hard to read as good literature, Macaria is still important for the current dissertation. The preface and the dialogue form, but also, explicit references to More and Bacon posit the work in the realm of fiction. There is no attempt, however, to leave any space for ambiguity here: the preface is separate from the main text, and no playfulness, no blurring of fiction and non-fiction is to be found. The fictional form is used solely to "teach," and the function of "delight" is non-existent in the work.

\section{The Blazing World}

Margaret Cavendish's The Blazing World is in many respects similar to Macaria, but in one respect - length - it is the complete opposite. The work is about 170 pages long, but its

\footnotetext{
${ }^{163}$ It must be quickly added, though, that OED traces the use of the word already from the 15 th century.
} 
paratextual aspect is similarly moderate, offering only one dedicatory poem, a preface, and an epilogue for the reader. The reflection on fiction is more elaborate than anything seen before, and Cavendish integrates many of the insights offered by previous authors. First of all, there is a strong parallel between Bacon and Cavendish in that The Blazing World was first published in 1666 together with, or rather as an appendix to her immense volume Observations upon Experimentall Philosophy. The dual publication was reissued in 1668, and in the same year, The Blazing World was also published independently. This independent version made some rearrangements in the paratexts, necessitated by the removal of the philosophical work to which the first version of the preface made frequent references. ${ }^{164}$

The dedicatory poem by William Newcastle contains important remarks on the uses of fiction, and when it draws a parallel between the real world and the world created in fiction, we are reminded to Hall's concept of exploring a new world through reading:

Then what are You, having no Chaos found

To make a World, or any such least ground?

But your Creating Fancy, thought it fit

To make your World of Nothing, but pure Wit. (Claeys 2000, 55)

The same praise of the power of creative wit is given a fuller exposition in the preface to the reader. The longer version commences with an excuse for juxtaposing the two works, pretty much in the manner of William Rawley, emphasising that the joint publication does not mean that in the authoress's opinion "this noble study were but a Fiction of the Mind" (Claeys 2000, 55). This is followed by a comparison between philosophy and fiction, declaring that whereas the former is based on Reason, fiction is "an issue of mans Fancy". Fiction is defined as a "voluntary creation of the Mind", as opposed to Reason, which is, in her view, "a rational

\footnotetext{
${ }^{164}$ The most important change might be the one concerning the addressee of the preface: while the original was talking "To the reader", the independent publication is more specific, speaking "To all Noble and Worthy Ladies". See Cavendish 1666, and Cavendish 1668b.
} 
search and enquiry into the causes of natural effects" (Ibid.). Cavendish also stresses that it is unimportant whether the things in fiction are "existent without his mind or not" (remarkably the text consistently uses the male pronoun) and sees the purpose of fiction in that it can "recreate the Mind, and withdraw it from its more serious Contemplations" (Ibid.). Next, she differentiates the three parts of the text as romancical, philosophical, and "meerly Fancy" (Ibid.). Even though philosophy and fiction are juxtaposed in the first part of the preface, here fancy (that is, fiction) may appear as something less valuable (meerly Fancy). Nonetheless, even if it should be less valuable than philosophy, the real importance of Cavendish's concept lies in the fact that she attributes an inherent, independent function to fiction. Instead of a device, as we saw in Plattes', or in Hall's, but above all, in the Elizabethan dialogues' case, in this text we find a complete exploitation of the (voluntary) creative aspect of fiction, a praise of fiction for fiction's sake, which of course has a somewhat melancholic tone in the final remarks of the preface:

(...) I endevalthough I cannot be Henry the Fifth, or Charles the Second, yet I endeavour to be Margaret the First; and although I have neither power, time nor occasion to conquer the world as Alexander and Caesar did; yet rather then not to be Mistress of one, since Fortune and the Fates would give me none, I have made a World of my own. (Claeys 2000, 56)

Probably there is no need for more quotations in support of the suggestion that the first female utopian writer is an equal to its predecessors when it comes to the elaboration of her own theoretical-fictional character. From her references, however, there is not much to learn about her position to the English tradition. Even when she mentions the "World in the Moon" (Ibid), she refers not to the Englishman Godwin's Man in the Moon (published in 1637), but to the "French man". Besides this reference to Cyrano de Bergerac's L'Autre Monde: ou les États et Empires de la Lune (published nine years before Cavendish's work), only Lucian is mentioned. 
As for dialogicity, it is used in a way mostly resembling Bacon's pragmatic use of the dialogue form. Most of the text is involved in the appropriation of the knowledge available in the new wold discovered by the heroine, and the best method for this is dialogue. This is, however, obviously different from More's use of the form, and it is also far from the polemical dialogue's use of the form, or even from Hall's reduced method. Something is changing here, and Chordas offers the following explanation for the change:

As the novelty of the New World wears off and the earth's geography becomes increasingly documented, early modern Utopias retreat, along with dialogue, into an interior space. Though filled with discourse, this is no longer represented in the form known as 'dialogue'; rather, dialogue becomes (as in Bacon) speech reported as part of the narrative, no longer constituting the narrative in itself. (...) I would argue that dialogue, whether directly represented or not, permeates the very way of thinking about utopia in this period. (Chordas 2010, 28)

\subsection{Conclusion}

The list of examples could be easily expanded, but Chordas' quotation is probably a good place to jump off the bandwagon. Her observation holds equally true for the paratextual aspect of utopian texts. What she describes is in fact nothing more than a process of naturalisation. My dissertation provided several examples of extremities in the use of both the paratexts and the dialogue form. However, as two of the reviewed later texts showed, the tendency which begins probably with Bacon, namely the demand for a more integrated, more natural use of the two investigated constituents of utopian texts, becomes more or less the standard. The third text, Macaria, also warned us that this is not an universal demand: in some cases, the constituents are split, and used selectively. Even so, it is this process of naturalisation that finally gave way to the birth of novels which rely on the utopian textual tradition. Swift's Gulliver's travells and Defoe's Robinson Crusoe utilise many elements of this tradition. However, they do this after both the paratextuality and the dialogue form have 
become more natural elements of utopias, precisely as described by Chordas. In my opinion, in both cases (paratexts, dialogue form) this process is determined by the changing attitude to fiction in utopias, which on the other hand, certainly reflects changing attitudes to fiction in general. Only after fiction could be taken for granted, only without the excuses, suspicions, and the constant balancing between acknowledging and denying it, only then could utopian fiction be absorbed by that literature which is not preceded by the label "utopian". ${ }^{165}$

My dissertation set out to explore the ways in which paratextuality and dialogicity are utilised by early modern English utopias. It has been proved that these previously underrepresented aspects are highly relevant to this corpus. If we add that because of spatial and temporal limitations, only a fragment of this corpus could be studied here, it becomes clear that the work has only begun. The pieces which could only be briefly reviewed here should be analysed more thoroughly, and there are ranks of $17^{\text {th }}$ century utopian texts waiting to be studied. It has hopefully been confirmed by now that if their study follows the thread of paratextuality and dialogicity, many new insights are to be gained.

\footnotetext{
${ }^{165}$ An important step in this direction is Francis Godwin's mentioned Man in the Moon. That text is not an utopia, but utopia plays a significant role in about a third of the text, whereas other parts are more influenced by the picaresque and the travel literature tradition. Godwin's text is obviously the most close to the novel form out of all the $17^{\text {th }}$ century English utopias I know. In line with my thesis, its preface appeals to the "fancy" of the reader. Cf. Godwin $(2009,67)$.
} 


\section{Works Cited}

\section{Primary sources}

CAVENDISH, Margaret. 1666. Observations upon experimental philosophy. To which is added, the description of a new blazing world. Written by the thrice noble, illustrious, and excellent princesse, the Duchess of Newcastle. London : printed by A. Maxwell, in the year, 1666. Wing (CD-Rom, 1996), N857, N849, ESTC R32311.

CAVENDISH, Margaret. 1668. Observations upon experimental philosophy: to which is added, The description of a new blazing world. Written by the thrice noble, illustrious, and excellent Princesse, the Duchess of Newcastle. Wing (CD-ROM, 1996), N858, ESTC R32163.

CAVENDISH, Margaret. 1668. The description of a new world, called the blazing-world. Written by the thrice noble, illustrious, and excellent princesse, the Duchess of Newcastle. London : printed by A. Maxwell, in the year M.DC.LX.VIII. [1668]. Wing (CD-ROM, 1996), N850, ESTC R13228.

FERRARIUS, Johannes. 1559. A Vvoorke of Ioannes Ferrarius Montanus, Touchynge the Good Orderynge of a Common Weale Wherein Aswell Magistrates, as Priuate Persones, Bee Put in Remembraunce of their Dueties, Not as the Philosophers in their Vaine Tradicions Haue Deuised, but According to the Godlie Institutions and Sounde Doctrine of Christianitie. Englished by William Bauande. Ed. William Bavande. [London] : 1559. Imprinted at London, by Ihon Kingston, for Ihon Wight, dewllyng in Poules Churchyarde. STC (2nd ed.), 10831, ESTC S102013.

HAKLUYT, Richard. 1598-1600. The Principal Navigations, Voyages, Traffiques, and Discoveries of the English Nation... 3 Vol. London: George Bishop, Ralph Newberie, Robert Barker. STC (2nd ed.), 12626a, ESTC S106753.

[HALL, Joseph.] 1605/6. Mundus alter et idem siue Terra Australis ante hac semper incognita longis itineribus peregrini academici nuperrime lustrata auth: Mercurio Britannico. Ed. William Knight. Francofurti [i.e. London : Printed by Humphrey 
Lownes, sold] apvd haeredes Ascanij de Rinialme. STC (2nd ed.), 12685, ESTC S103729.

[HALL, Joseph.] 1609. The Discouery of a New World Or A Description of the South Indies Hetherto Vnknowne by an English Mercury. Eds. Gentili and Alberico. [London] : Imprinted for Ed. Blount, and W. Barrett. STC (2nd ed.), 12686, ESTC S92843.

[HALL, Joseph.] 1613. The Discouery of a New World Or A Description of the South Indies Hetherto Vnknowne by an English Mercury. Eds. Gentili and Alberico. [London] : Imprinted for Ed: Blount. and W. Barrett, [1613 or 1614]. STC (2nd ed.), 12686.3, ESTC S103684.

LUPTON, Thomas. 1580. Siuqila Too Good, to be True : Omen : Though so at a Vewe Yet all I Tolde You is True, I Vpholde You, Now Cease to Aske Why? for I can Not Lye : Herein is Shewed by Way of Dialogue, the Wonderful Maners of the People of Mauqsun, with Other Talke Not Friuolous. Printed at London : By H. Bynneman, dwelling in Thames Streate, neere vnto Baynards Castell, 1580. STC (2nd ed.), 16951, ESTC S94052.

MORE, Thomas. "De optimo reipublicae statu, deque nova insula Utopia." Digitale Sammlungen der UB Bielefeld. 1518. <De optimo reipublicae statu, deque nova insula Utopia>, accessed 29 Jan 2013.

[NICHOLLS, Thomas.] 1579a. A Pleasant Dialogue. Betweene a Lady Called Listra, and a Pilgrim Concerning the Gouernment and Common Weale of the Great Prouince of Crangalor. 1579. Imprinted at London : By Iohn Charlewood, dwelling in Barbican at the signe of the halfe Egle and Keye, [1579]. STC (2nd ed.), 18335.5, ESTC S110071.

[---. 1579b.] The Second Part of the Painefull Iorney of the Poore Pylgrime into Asia, and the Straynge Wonders that He Sawe: Both Delectable and Profytable, in Sequell of the Lytle Dialogue, Betweene the Lady Lystra, and the Same Pilgrime. Imprinted at London : By Iohn Charlewood, dwelling in Barbican at the signe of the halfe Egle and Keye, [1579]. STC (2nd ed.), 18335.5, ESTC S110071.

[PLATTES, Gabriel. 1641.] A Description of the Famous Kingdome of Macaria, Shewing its Excellent Government Wherein the Inhabitants Live in Great Prosperity, Health, and 
Happiness : The King Obeyed, the Nobles Honoured, and all Good Men Respected, Vice Punished, and Vertue Rewarded: An Example to Other Nations between a Schollar and a Traveller. London: Printed for Francis Constable, 1641. Wing (2nd ed.), P2409A, ESTC R16655.

QUEVEDO, Francisco de. 1684. The Travels of Don Francisco De Quevedo through Terra Australis Incognita Discovering the Laws, Customs, Manners and Fashions of the South Indians : A Novel, Originally in Spanish. Eds. Hall and Joseph. London : Printed for William Grantham ..., 1684. Wing (CD-ROM, 1996), H422A, ESTC R40274.

STUBBES, Phillip. 1583. The Anatomie of Abuses Containing, a Discouerie, Or Briefe Summarie of such Notable Vices and Imperfections, as Now Raigne in Many Countreyes of the World: But (Especiallye) in a Famous Ilande Called Ailgna: Together, with most Fearefull Examples of Gods Iudgements, Executed Vppon the Wicked for the Same, Aswel in Ailgna of Late, as in Other Places, Elsewhere. very Godly, to be Reade of all True Christians: But most Needefull to be Regarded in Englande. made Dialogue-Wise by Phillip Stubbes. Seene and Allowed, According to Order. Printed at London : By [John Kingston for] Richard Iones, [1583]. STC (2nd ed.) 23377, ESTC S122316.

\section{Secondary sources}

""Utopia, n."." Oxford English Dictionary. September 2011.

<http://www.oed.com/view/Entry/220784>, accessed 19 Nov 2012.

ALEXANDER, Gavin. 2004. Sidney's 'the Defence of Poesy' and Selected Renaissance Literary Criticism. London; New York: Penguin.

ALLEN, Peter R. 1963. "Utopia and European Humanism: The Function of the Prefatory Letters and Verses." Studies in the Renaissance 10: 91-107. 
ANDREW, Malcolm. 1984. Two Early Renaissance Bird Poems: The Harmony of Birds, the Parliament of Birds. 10 Vol. Associated University Presses.

APPELBAUM, Robert. 2002. Literature and Utopian Politics in Seventeenth-Century England. Cambridge: Cambridge UP.

ASHWORTH-KING, Erin L. 2009. "The Ethics of Satire in Early Modern English Literature." PhD University of North Carolina - Chapel Hill.

BALDWIN, R. C. D. "Nicholls, Thomas (1532-1601)." Oxford Dictionary of National Biography. 2008. <http://www.oxforddnb.com/view/article/20124>, accessed 1 Jan 2013.

BARKER, Arthur E. 1966. "Clavis Moreana: The Yale Edition of Thomas More." The Journal of English and Germanic Philology 65.2 : 318-30.

BENNEL, John. "Robinson, Ralph (1520-1577)." Oxford Dictionary of National Biography. 2004. <http://www.oxforddnb.com/view/article/23863>, accessed 25 February 2013.

BEVINGTON, David M. 1961. "The Dialogue in "Utopia": Two Sides to the Question." Studies in Philology 58.3 : 496-509.

BIETENHOLZ, Peter G. 1994. Historia and Fabula: Myths and Legends in Historical Thought from Antiquity to the Modern Age. Leyden: Brill (Brill's Studies in Intellectual History 59.)

BINDER, James. 1947. "More's Utopia in English: A Note on Translation." Modern Language Notes 62.6 : 370-6.

BISHOP, Malcolm. 2005. "Ambrosius Holbein's Memento Mori Map for Sir Thomas More's Utopia. the Meanings of a Masterpiece of Early Sixteenth Century Graphic Art." British dental journal 199.2 : 107-12.

BLAIM, Artur. 1982. "More's Utopia: Persuasion Or Polyphony?" Moreana: Bulletin Thomas More $19.73: 5-20$. 
BOESKY, Amy. 1997. "Bacon's New Atlantis and the Laboratory of Prose." The Project of Prose in Early Modern Europe and the New World. Eds. Elizabeth Fowler and Roland Greene. Cambridge: Cambridge UP, 138-153.

BROWN, Huntington. 1967 [1933]. Rabelais in English Literature. New York: Octagon Books.

BRUCE, Susan, ed. 1999. Three Early Modern Utopias: (Utopia, New Atlantis, the Isle of Pines). Oxford: Oxford UP. (Oxford World Classics)

BRYSON, Alan. "Parliament of Birds." HRI - Origins of Early Modern Literature. 8 May 2007 2007. <http://www.hrionline.ac.uk/origins/DisplayServlet?id=Anon19303.7>, accessed 10 June 2013.

BURKE, Peter. 2007. "Cultures of Translation in Early Modern Europe." Cultural Translation in Early Modern Europe. Eds. Peter Burke and R. Po-chia Hsia. Cambridge: Cambridge UP, 7-38.

BURKE, Peter. 1989. "The Renaissance Dialogue." Renaissance Studies 3.1 : 1-12.

CAVE, Terence. 2008. Thomas More's Utopia in Early Modern Europe: Paratexts and Contexts. Manchester - New York: Manchester UP.

CHORDAS, Nina. 2010. Forms in Early Modern Utopia. the Ethnography of Perfection. Farnham: Ashgate.

CLAEYS, Gregory, ed. 2000. Restoration and Augustan British Utopias. Syracuse NY: Syracuse University Press.

COUSINS, A. D., and Damian GRACE. 2009. A Companion to Thomas More. MadisonTeaneck: Fairleigh Dickinson UP.

CRESSY, David. 1996. "Gender Trouble and Cross-Dressing in Early Modern England." The Journal of British Studies 35.4 : 438-65.

CULPEPER, Jonathan, and Merja KYTÖ. 1997. "Towards a Corpus of Dialogues, 15501750." Language in Time and Space. Studies in Honour of Wolfgang Viereck on the 
Occasion of His 60th Birthday. Eds. Heinrich Ramisch and Kenneth Wynne. Stuttgart: Franz Steiner Verlag, 60-73.

CULPEPER, Jonathan, and Merja KYTÖ. 2010. Early Modern English Dialogues : Spoken Interaction as Writing. Cambridge u.a.]: Cambridge u.a.] : Cambridge Univ. Press.

CUMMINGS, Brian. 2002. Grammar and Grace: The Literary Culture of the Reformation. Oxford: Oxford UP.

DAMRAU, Peter. 2006. The Reception of English Puritan Literature in Germany. London: Maney Publishing for MHRA. (MHRA texts and dissertations, 66.)

DAVIS, JC. 2008. "Going Nowhere: Travelling to, through, and from Utopia." Utopian Studies $19.1: 1-23$.

DAVIS, J. C. 1981. Utopia and the Ideal Society: A Study of English Utopian Writing 15161700. Cambridge: Cambridge UP.

DEAKINS, Roger. 1980. "The Tudor Prose Dialogue: Genre and Anti-Genre." Studies in English Literature, 1500-1900 20.1 : 5-23.

DEITCH, Judit. 1999. "'Dialoguewise:" Discovering Alterity in Elizabethan Dialogues." Other Voices, Other Views: Expanding the Canon in English Renaissance Studies. Eds. Helen Ostovich, Mary Vera Silcox, and Graham Roebuck. Newark, London: University of Delaware Press, Associated University Presses, 46-73.

DEITCH, Judith A. 1998. "The Genre of Logic and Artifice: Dialectic, Rhetoric, and English Dialogues, 1400-1600, Hoccleve to Spenser." PhD Dissertation (Doctor of Philosophy). Available via the National Library of Canada, <https://tspace.library.utoronto.ca/handle/1807/12400>, accessed 20 Nov 2012.

DICKSON, Donald R. 1998. The Tessera of Antilia. Utopian Brotherhoods \& Secret Societies in the Early Seventeenth Century. Leiden - Boston - Köln: Brill.

ELLIOTT, R. C. 1963. "The Shape of Utopia." English Literary History 30.4 : 317-34.

---. 1970. The Shape of Utopia: Studies in a Literary Genre. University of Chicago Press. 
ERASMUS, D. 2008. The Praise of Folly. Tran. John Wilson. Arc Manor.

EVANS, Scott D. 1996. "A" Divine Consideration": Utopia in Sidney's Defence of Poetry." Moreana: 7-30.

FAUSETT, David. 1993. Writing the New World. Imaginary Voyages and Utopias of the Great Southern Lands. Syracuse, NY: Syracuse UP.

FERNS, C. 1999. Narrating Utopia: Ideology, Gender, Form in Utopian Literature. Liverpool UP.

FORSYTH, Neil. 2008. John Milton: A Biography. Oxford: Lion Books.

FORTIER, Mardelle L., and Robert F. FORTIER. 1992. The Utopian Thought of St. Thomas More and its Development in Literature. Lewiston, N.Y.: E. Mellen Press.

FRYE, Northrop. 1990 [1957]. Anatomy of Criticism. Princeton: Princeton UP.

FRYE, Northrop. 1967 [1965]. "Varieties of Literary Utopias." Utopias and Utopian Thought. A Timely Appraisal. Ed. Frank E. Manuel. Boston: Beacon Press, 25-50.

GARBER, Marjorie. 1997. Vested Interests: Cross-Dressing and Cultural Anxiety. Psychology Press.

GENETTE, Gérard. 1997. Paratexts: Thresholds of Interpretation. 20 Vol. Cambridge University Press.

GHITA, Lucian. 2006. "'I would rather be Honest than Wise': Fictional Protocols and Authorial Credibility in Thomas More's Utopia." Prose Studies: History, Theory, Criticism 28.2 : 113-29.

GILBERT, Ruth. 2002. Early Modern Hermaphrodites: Sex and Other Stories. Palgrave New York.

GODWIN, Francis. 2009. The Man in the Moone. Ed. William Poole. Peterborough: Broadview. 
GOHLKE, Madelon S. 1976. "Wits Wantonness: "The Unfortunate Traveller" as Picaresque." Studies in Philology 73.4 : 397-413.

GRACE, Damian. 1989. "Utopia: A Dialectical Interpretation." Eds. Clare M. Murphy, Henri Gibaud, and Mario Di Cesare. Binghamton: Medieval \& Renaissance Texts \& Studies, 273-302. Moreana 100: 26 .

GREENBLATT, Stephen. 1988. Shakespearean Negotiations: The Circulation of Social Energy in Renaissance England. Univ of California Press.

GUY-BRAY, Stephen. 2007. "How to Turn Prose into Literature: The Case of Thomas Nashe." Early Modern Prose Fiction. the Cultural Politics of Reading. Ed. Naomi Conn Liebler. London-New York: Routledge, 33-45.

HADFIELD, Andrew. 1998. Literature, Travel, and Colonial Writing in the English Renaissance, 1545-1625. Oxford: Oxford UP.

HALL, Joseph. 1949. The Poems of Joseph Hall. Ed. A. Davenport. Liverpool: Liverpool University Press.

HAMMOND, Brean, and Shaun REGAN. 2006. Making the Novel: Fiction and Society in Britain, 1660 - 1789. Basingstoke u.a.]: Basingstoke u.a.] : Palgrave Macmillan.

HEITSCH, Dorothea, and Jean François VALLÉE, eds. 2004. Printed Voices : The Renaissance Culture of Dialogue. Toronto: University of Toronto Press.

HERFORD, Charles Harold. 1886. Studies in the Literary Relations of England and Germany in the Sixteenth Century. Cambridge: Cambridge UP.

HIRZEL, Rudolf. 1895. Der Dialog: Ein Literarhistorischer Versuch. 2 Vol. Leipzig: S. Hirzel.

HOLSTUN, James. 1987. A Rational Millenium; Puritan Utopias of 17th-Century England and America. New York u.a.]: Oxford Univ. Press.

HONGYING, Niu. 2007. "Robinson Crusoe and Utopian Thought of the West." Foreign Literature Studies 29.5 : 84-9. 
HOUSTON, Chlöe. 2007. "Utopia, Dystopia Or Anti-Utopia? Gulliver's Travels and the Utopian Mode of Discourse." Utopian Studies 18.3, Irish Utopian : 425-42.

HOWARD, Jean E. 1988. "Crossdressing, the Theatre, and Gender Struggle in Early Modern England." Shakespeare Quarterly 39.4 : 418-40.

---. 1994. The Stage and Social Struggle in Early Modern England. Routledge.

HÖLSCHER, Lucian. 1996. "Utopie." Utopian Studies 7.2 : 1-65.

KENDRICK, Christopher. 2004. Utopia, Carnival, and Commonwealth in Renaissance England. Toronto: University of Toronto Press.

KENNEDY, Ross. "Bavand, William (fl. 1559)." Oxford Dictionary of National Biography. 2004. <http://www.oxforddnb.com/view/article/1724>, accessed 11 July 2013.

KOPPENFELS, W. von. 1981. "Mundus Alter Et Idem. Utopie Fiktion Und Menippeische Satire.(M... Fiction Utopique Et Satire Ménippée)." Poetica.Zeitschrift für Sprach-und Literaturwissenschaft München 13.1-2 : 16-66.

KUMAR, Krishan. 1987. Utopianism Ancient and Modern. Oxford: Blackwell.

KYTÖ, Merja, and Terry WALKER. 2006. "Guide to A Corpus of English Dialogues 15601760." . Uppsala: Acta Universitatis Upsaliensis. (Studia Anglistica Upsaliensia 130).

LAKOWSKI, Romuald Ian. 1993. "Sir Thomas More and the Art of Dialogue." University of British Columbia, <http://extra.shu.ac.uk/emls/iemls/work/chapters/contents.html>, accessed 20 Sep 2012.

LEWIS, Clive Staples. 1954. English Literature in the Sixteenth Century, Excluding Drama. Eds. Dobrée Bonamy and Davis Norman. 3 Vol. Clarendon Press. (The Oxford History of English Literature.)

LOGAN, George. 1994. "Utopia and Deliberative Rhetoric." Moreana 118/119: 103-20.

MACZELKA, Csaba. 2012. "Joseph Hall's Mundus Alter Et Idem and Cross-Dressing in Early Modern England." Gender Studies.11 : 98-121. 
MANCALL, Peter C. 2007. Hakluyt's Promise: An Elizabethan's Obsession for an English America. Yale University Press.

MANUEL, Frank E., and Fritzie P. MANUEL. 1979. Utopian Thought in the Western World. Cambridge, MA: The Belknap Press.

MCCABE, Richard A. 1982. Joseph Hall. A Study in Satire and Meditation. Oxford: Clarendon Press.

MCCUTCHEON, Elizabeth. 1971. "Denying the Contrary: More's use of Litotes in the Utopia." Moreana: Bulletin Thomas More 31-32: 107-21.

MERRILL, Elizabeth. 1911. The Dialogue in English Literature. H. Holt and company.

MILTON, John. 1641 [1953]. "An Apology Against a Pamphlet Called A Modest Confutation of the Animadversions upon the Remonstrant Against Smectymnuus." Complete Prose Works of John Milton 1. 1624-1642. New Haven: Yale UP, 880-881.

---. 1644 [1985]. "Areopagitica." John Milton: Selected Prose. Ed. C. A. Patrides. Columbia: Univ. of Missouri Press, 196-249.

---. 1995. Utopia. Latin Text and English Translation. Ed. George M. Logan,Robert M.Adams, Clarence H.Miller. Cambridge: CUP.

MORE, Thomas, 1478-1535, Edward SURTZ, and Louis L. MARTZ. 1965. The Complete Works of St. Thomas More. 4. Utopia. New Haven, Conn.u.a.]: New Haven, Conn.u.a.] : Yale Univ. Press.

MUTHER, Theodor. "Ferrarius, Johannes." Deutsche Biographie. [2013]. <http://www.deutsche-biographie.de/pnd124596592.html?anchor=adb>, accessed 1 July 2013.

NASHE, Thomas. 1920. The Unfortunate Traueller, Or the Life of Jacke Wilton. Ed. H. F. B. Brett-Smith. Oxford: Basil Blackwell.

O'BRIEN, Brian. 1992. "J. H. Hexter and the Text of Utopia: A Reappraisal." Moreana: Bulletin Thomas More 29.110 : 19-32. 
OLIN, John. 1994. Erasmus, Utopia and the Jesuits: Essays on the Outreach of Humanism. Fordham UP.

ORGEL, Stephen. 1996. Impersonations: The Performance of Gender in Shakespeare's England. Cambridge: Cambridge UP.

PARRISH, John Michael. 1997. "A New Source for More's 'Utopia'." The Historical Journal $40.2: 493-8$.

PATRICK, J. Max. 1977. "Nova Solyma: Samuel Gott's Puritan Utopia." Studies in the Literary Imagination $10.2: 43-55$.

PELTONEN, Markku. 2002. "Citizenship and Republicanism in Elizabethan England." Republicanism: A Shared European Heritage. Vol. 1. Republicanism and Constitutionalism in Early Modern Europe. Eds. Martin van Gelderen and Quentin Skinner. 1 Vol. Cambridge University Press, 85-106.

PINTÉR, Károly. 2010. The Anatomy of Utopia. Narration, Estrangement and Ambiguity in More, Wells, Huxley and Clarke. Jefferson - North Carolina - London: McFarland.

PURPUS, Eugene R. 1950. "The "Plain, Easy, and Familiar Way": The Dialogue in English Literature, 1660-1725." ELH 17.1 : 47-58.

RECKWITZ, Erhard. 1976. Die Robinsonade; Themen Und Formen Einer Literarischen Gattung. Amsterdam: Grüner.

REYNOLDS, Ernest Edwin, 1894-. 1965. Thomas More and Erasmus. London: London : Burns \& Oates.

ROSSBACH, Nikola. 2006. "Schlaraffische Texte Und Welten Uberlegungen $\mathrm{Zu}$ Moglichkeiten Und Grenzen Einer Kulturwissenschaftlichen Literaturwissenschaft." Daphnis-Zeitschrift für Mittlere Deutsche Literatur 35.3-4 : 495-514.

SALZMAN, Paul Jacob. 2002. "Narrative Contexts for Bacon's New Atlantis." Francis Bacon's New Atlantis. New Interdisciplinary Essays. Ed. Brownen Price. Manchester, UK; New York: Manchester University Press, 28-47. 
SARGENT, Lyman Tower. 1988. British and American Utopian Literature: 1516-1975. New York: Garland.

---. 1976. "Themes in Utopian Fiction in English before Wells." Science Fiction Studies 3.3, Science Fiction before Wells : 275-82.

---. 1983. "Utopia and the Family: A Note on the Family in Political Thought." Dissent and Affirmation: Essays in Honor of Mulford Q. Sibley. Eds. Arthur L. Kalleberg, James Donald Moon, and Daniel R. Sabia Jr.Popular Press, 106-117.

---. 2010. Utopianism. A very Short Introduction. Oxford: OUPVery Short Introductions .

SAYLER, SM. 1927. "Renaissance Influences in Hall's Mundus Alter Et Idem." Philological Quarterly 6: 321-34.

SCHOECK, R. J. 1969. "'A Nursery of Correct and Useful Institutions': On Reading More's Utopia as Dialogue." Moreana: Bulletin Thomas More 22: 19-32.

SEIDEL, Robert. 1994. Späthumanismus in Schlesien: Caspar Dornau (1577-1631). Leben Und Werk. Walter de Gruyter.

SHRANK, Cathy. "A Pleasant Dialogue between Listra and a Pilgrim." HRI - Origins of Early Modern Literature.

<http://www.hrionline.ac.uk/origins/DisplayServlet?id=TN18335.5\&type=normal>, accessed 10 May 2013.

SKINNER, Quentin. 1967. “More's Utopia. Review article.” Past and Present, 38, 153-168.

SKINNER, Quentin. 1978 [1994]. The Foundations of Modern Political Thought. 2 Vol. Cambridge: Cambridge UP.

SMITH, D. B. 1991. More's Utopia. London: Harper Collins Acad.

SNYDER, Jon R. 1989. Writing the Scene of Speaking : Theories of Dialogue in the Late Italian Renaissance. Stanford, Calif.: Stanford UP. 
STRÄTER, Udo. 1987. Sonthom, Bayly, Dyke Und Hall: Studien Zur Rezeption Der

Englischen Erbauungsliteratur in Deutschland Im 17. Jahrhundert. Mohr Siebeck.

SZÖNYI, György Endre. 2012. "Order and its Subversion in Dress-Code: Crossdressing." The Iconology of Law and Order (Legal and Cosmic). Eds. Anna Kérchy, Attila Kiss, and György Endre Szőnyi. Szeged: JATEPress, 110-122. Papers in English \& American Studies XXI.

VALLÉE, Jean François. 2004. "The Fellowship of the Book: Printed Voices and Written Friendships in More's Utopia." Printed Voices: The Renaissance Culture of Dialogue. Eds. Dorothea Heitsch and Jean François Vallée. Toronto: University of Toronto, 42-62.

WALSHAM, Alexandra. "Stubbes , Philip (b. c.1555, d. in or after 1610)." Oxford Dictionary of National Biography. 2004. <http://www.oxforddnb.com/view/article/26737>, accessed 12 Aug 2013.

WANDS, John M. 1981a. "Antipodal Imperfection - Hall's Mundus Alter Et Idem and its Debt to More's Utopia." Moreana 18.69 : 85-100.

WANDS, John Millar. 1981b. Another World and Yet the Same. Bishop Joseph Hall's Mundus Alter Et Idem. New Haven - London: Yale UP.

---. 1980. "The Early Printing History of Joseph Hall's Mundus Alter Et Idem." The Papers of the Bibliographical Society of America 74.

WARNER, J. Christopher. 2004. "Thomas More's Utopia and the Problem of Writing a Literary History of English Renaissance Dialogue." Printed Voices: The Renaissance Culture of Dialogue. Eds. Dorothea Heitsch and Jean François Vallée. Toronto: University of Toronto, 63-76.

WEBSTER, Charles. 1972. "The Authorship and Significance of Macaria." Past and Present 56: $34-48$.

WILSON, Kenneth Jay. 1985. Incomplete Fictions: The Formation of English Renaissance Dialogue. Catholic University of America Press. 
WINTER, Michael. 1978. Compendium Utopiarum: Typologie Und Bibliographie

Literarischer Utopien. JB Metzlersche Verlagsbuchhandlung.

WOLF, Erik. "Cantiuncula, Claudius (Claude Chansonet, Chansonnette)." Deutsche Biographie. [2013]. <http://www.deutsche-biographie.de/pnd118666959.html>, accessed 12 July 2013 .

WOODEN, Warren W. 1978. "A Reconsideration of the Parerga of Thomas More's" Utopia"." Albion: A Quarterly Journal Concerned with British Studies 10: 151-60.

WOODEN, Warren W., and JN WALL JR. 1985. "Thomas More and the Painter's Eye: Visual Perspective and Artistic Purpose in More's Utopia." The Journal of medieval and Renaissance studies 15.2 : 231-63.

YORAN, Hanan. 2010. Between Utopia and Dystopia: Erasmus, Thomas More, and the Humanist Republic of Letters. Lexington Books.

ZLATAR, Antoinina Bevan. 2011. Reformation Fictions: Polemical Protestant Dialogues in Elizabethan England. Oxford UP. 


\section{Appendices}

\section{Appendix 1. Paratext nr. 3 in More's Utopia (Anemolius' hexastichon)}

Hexastichon Anemolii poetae laureate, Hythlodaei ex sorore nepotism in utopiam insulam. (Complete Works 4, 20)

Utopia priscis dicta, ob infrequentiam,

Nunc civitatis aemula Platonicae,

Fortasse victrix, (nam quod illa literis

Deliniauit, hoc ego una praestiti,

Viris \& opibus, optimisque legibus)

Eutopia merito sum uocanda nomine.

Six lines on the island of Utopia by Anemolius, poet laureate, nephew of Hythlodaeus by his sister (prose translation from CW 4, 21)

The ancients called me Utopia or Nowhere, because of my isolation. At present, however, I am a rival of Plato's republic, perhaps even a victor over it. The reason is that what he has delineated in words I alone have exhibited in men and resources and laws of surpassing excellence. Deservedly ought I to be called by the name of Eutopia or Happy Land.

Six lines on the island of Utopia written by Anemolius, poet laureate, and nephew to Hythloday by his sister (verse translation from More 1995, 19)

'No-Place was once my name, I lay so far;

But now with Plato's state I can compare,

Perhaps outdo her (for what he only drew

In empty words I have made live anew

In men and wealth, as well as splendid laws):

'The Good Place' they should call me, with good cause. 
Source: (Nicholls 1579a, B1v-B3r)

And againe when the complaint of the poore commeth before the Iudges in the iudicial Hall, then saith the Attorny of the poore, who hath also his wages of the Citizens. My Lords, it may please you to heare a poore mans cause. This voyce is no sooner heard, when the Iudges staieth all matters, except it touch the estate, and incontinent the poore mans sute is dispatched: for if it should not be so, then many times would it happen, as once a sute depending betweene a poor Poticary and a Butcher, for when their Plea is determined by the inferior Iudge: the Poticary caried priuely to the Iudge a little Pot of Conserua, beseeching him to remember his matter against the butcher. The Iudge tooke it and sayde he would prouide Iustice. But when the Butcher heard of the presenting of this bribe, he went and killed a good fat Hog and brought it to the Iudge, requesting his fauor against the Poticary: the Iudge also receiued it, and bad him depart. It so fell out, that the sentence passed on the Butchers syde. But when the poore Poticary had notice thereof, he came railing to the Iustice house, saying to the Iudge: syr how chaunst you remembred not both my right \& pot of Conserua. Yes quoth the Iudge, I remember them bothe, but as for your Conserua, there came a Hog \& threw down your pot, ye \& spilt it, so that I neuer found any sweetenes therein. Mary sir quoth the Poticary a murraine and a pestilence take such a Hog that spilt both my Iustice and Conserua. So that Madam I tell you this merry tale, to the ende that you may know how in this happy Lande, it preuaileth not for the ritch to say I haue a fat purse: for why, the good Iudges, hath so great a feare of God and the Prince, that no corruption can auaile. And certainely the godly Diuines, are a great cause thereof, for they will not let to tell all estates their faultes, by some honest meanes: by reason whereof, they doo well know, that they themselues, shall come to iudgement, and be Iudged, so that according to the oppinion of S. Ierom, they haue dayly the sounde of the Trumpet in their eares, that shall call to Iudgement. And this is the principall cause, that they do liue in the feare of God, and are blessed. 


\section{Appendix 3. Excerpt from John Milton's An apology against a pamphlet called A modest confutation of the animadversions upon the remonstrant against Smectymnuus (1642)}

Source: http://oll.libertyfund.org/simple.php?id=1209.

As therefore he began in the title, so in the next leaf he makes it his first business to tamper with his reader by sycophanting and misnaming the work of his adversary. He calls it "a mime thrust forth upon the stage, to make up the breaches of those solemn scenes between the prelates and the Smectymnuans." Wherein while he is so over-greedy to fix a name of ill sound upon another, note how stupid he is to expose himself or his own friends to the same ignominy; likening those grave controversies to a piece of stagery, or scenework, where his own Remonstrant, whether in buskin or sock, must of all right be counted the chief player, be it boasting Thraso, or Davus that troubles all things, or one who can shift into any shape, I meddle not; let him explicate who hath resembled the whole argument to a comedy, for "tragical," he says, "were too ominous." Nor yet doth he tell us what a mime is, whereof we have no pattern from ancient writers, except some fragments, which contain many acute and wise sentences. And this we know in Laertius, that the mimes of Sophron were of such reckoning with Plato, as to take them nightly to read on, and after make them his pillow. Scaliger describes a mime to be a poem intimating any action to stir up laughter. But this being neither poem, nor yet ridiculous, how is it but abusively taxed to be a mine? For if every book, which may by chance excite to laugh here and there, must be termed thus, then may the dialogues of Plato, who for those his writings, hath obtained the surname of divine, be esteemed as they are by that detractor in Athenæus, no better than mimes. Because there is scarce one of them, especially wherein some notable sophister lies sweating and turmoiling under the inevitable and merciless dilemmas of Socrates, but that he who reads, were it Saturn himself, would be often robbed of more than a smile. And whereas he tells us, that "scurrilous Mime was a personated grim lowering fool," his foolish language unwrittingly writes fool upon his own friend, for he who was there personated was only the Remonstrant; the author is ever distinguished from the person he introduces. But in an ill hour hath this unfortunate rashness stumbled upon the mention of miming, that he might at length cease, which he hath not yet since he stepped in, to gall and hurt him whom he would aid. Could he not beware, could he not bethink him, was he so uncircumspect as not to foresee, that no sooner would that word mime be set eye on in the paper, but it would bring to mind that wretched pilgrimage over Minshew's dictionary called "Mundus alter et idem," the idlest and paltriest mime that ever mounted upon bank? Let him ask "the author of those toothless satires," who was the maker, or rather the anticreator of that universal foolery, who he was, who like that other principal of the Manichees the arch evil one, when he had looked upon all that he had made and mapped out, could say no other but contrary to the divine mouth, that it was all very foolish. That grave and noble invention, which the greatest and sublimest wits in sundry ages, Plato in Critias, and our two famous countrymen, the one in his "Utopia," the other in his "New Atlantis," chose, I may not say as a field, but as a mighty continent, wherein to display the largeness of their spirits, by teaching this our world better and exacter things than were yet known or used: this petty previcator of America, the zany of Columbus, (for so he must be till his world's end,) having rambled over the huge topography of his own vain thoughts, no marvel if he brought us home nothing but a mere tankard drollery, a venereous parjetory for stews. Certainly, he that could endure with a sober pen, to sit and devise laws for drunkards to carouse by, I doubt me whether the very soberness of such a one, like an unliquored Silenus, were not stark drunk. Let him go now and brand another man injuriously with the name of Mime, being himself the loosest and most extravagant Mime that hath been heard of, whom no less than almost half the world could serve for stage-room to play the Mime in. And let him advise again with Sir Francis Bacon, whom he cites to confute others, what it is "to turn 
the sins of Christendoin into a mimical mockery, to rip up the saddest vices with a laughing countenance," especially where neither reproof nor better teaching is adjoined. Nor is my meaning, readers, to shift off a blame from myself, by charging the like upon my accuser, but shall only desire, that sentence may be respited, till I can come to some instance whereto I may give answer. 